Seri Agroforestri dan Kehutanan di Sulawesi:

Strategi mata pencaharian dan dinamika sistem penggunaan lahan di Sulawesi Selatan

Noviana Khusussiyah, Janudianto, Isnurdiansyah, S Suyanto dan James M Roshetko 

Seri Agroforestri dan Kehutanan di Sulawesi:

\section{Strategi mata pencaharian dan dinamika sistem penggunaan lahan di Sulawesi Selatan}

Noviana Khususiyah, Janudianto, Isnurdiansyah, S Suyanto dan James M Roshetko

Working Paper no. 164 


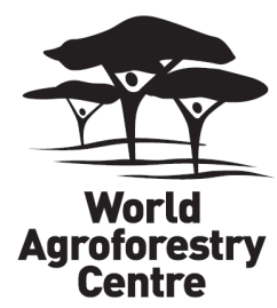

\section{Correct citation:}

Khususiyah N, Janudianto, Isnurdiansyah, Suyanto S dan Roshetko JM .2013. Seri Agroforestri dan Kehutanan di Sulawesi: Strategi mata pencaharian dan dinamika sistem penggunaan lahan di Sulawesi Selatan [Agroforestry and Forestry in Sulawesi series: Livelihood strategies and land use sistem dynamics in Sulawesi Selatan]. Working paper 164. Bogor, Indonesia: World Agroforestry Centre (ICRAF) Southeast Asia Wilayah Program. 40p. DOI: 10.5716/WP13040.PDF.

Titles in the Working Paper Series aim to disseminate interim results on agroforestry research and practices and stimulate feedback from the scientific community. Other publication series from the World Agroforestry Centre include: Agroforestry Perspectives, Technical Manuals and Occasional Papers.

Published by the World Agroforestry Centre

Southeast Asia Regional Program

PO Box 161, Bogor 16001

Indonesia

Tel: +62 2518625415

Fax: +62 2518625416

Email: icraf-indonesia@cgiar.org

Website: http://worldagroforestry.org/regions/southeast_asia

(C) World Agroforestry Centre 2013

Working Paper 164

\section{Photos:}

The views expressed in this publication are those of the author(s) and not necessarily those of the World Agroforestry Centre.

Articles appearing in this publication may be quoted or reproduced without charge, provided the source is acknowledged.

All images remain the sole property of their source and may not be used for any purpose without written permission of the source. 


\section{Tentang penulis}

Noviana Khususiyah adalah spesialis sosial ekonomi dan Livelihood di ICRAF Asia Tenggara. Dia memiliki banyak pengalaman profesional dalam survei rumah tangga, Participatory Rural Appraisals (PRA), dan Rapid Rural Appraisals (RRA). Fokus utamanya adalah mendapatkan data terkait dengan peningkatan mata pencaharian masyarakat, isu lingkungan dan gender. Dia mendapatkan gelar sarjana S2 dalam Ilmu Ekonomi (Perencanaan Pembangunan Wilayah dan Pedesaan, dengan konsentrasi pada Ekonomi Lingkungan) dari Institut Pertanian Bogor (IPB), Indonesia.

Janudianto mendapatkan gelar sarjana S1 Pertanian, dengan fokus utama pada Ilmu Tanah, dari Fakultas Pertanian, IPB. Dia bergabung dengan ICRAF Asia Tenggara pada 2005. Dia fokus pada pengembangan strategi terkait dengan petani dan mata pencaharian masyarakat, pengelolaan sistem agroforestri tradisional---terutama memperbaiki sistem agroforestri karet---dan penilaian agroekologi keanekaragaman hayati di Sumatra, Kalimantan, dan Sulawesi. Sekarang ini Janudianto bekerja sebagai spesialis pengelolaan agroforestri di ICRAF Asia Tenggara.

Isnurdiansyah mendapatkan gelar sarjana S1 dalam Ekonomi Agribisnis dari IPB pada 2010. Dia terlibat dalam beberapa studi sebagai konsultan bidang sosioekonomi. Dia bekerja untuk Kementerian Pertanian dari 2009 hingga 2011. Dia bergabung dengan ICRAF sebagai asisten peneliti dalam Unit Analisis Ekonomi dan Kebijakan untuk mendukung penelitian pembangunan sosioekonomi dan mata pencaharian.

S Suyanto memiliki gelar Ph.D. di bidang Ekonomi dari Tokyo Metropolitan University, Jepang. Dia saat ini menjabat sebagai Principal Scientist untuk bidang Kemiskinan, Layanan Lingkungan dan Hak Milik di ICRAF Asia Tenggara, Bogor, Indonesia. Dr. Suyanto berpengalaman selama lebih dari 15 tahun dalam pengelolaan sumber daya alam dan analisis kelembagaan. Dia sudah bekerja di Program Penelitian Wilayah Asia Tenggara untuk ICRAF yang berlokasi di Indonesia sejak 1994, dan selama itu dia sudah mengembangkan banyak keahlian dalam bidang sosioekonomi, ekonomi sumber daya alam, ekonometri, dan analisis kelembagaan. Selama lima tahun terakhir, dia mengelola beberapa proyek penelitian yang berhubungan dengan perubahan iklim dan pembayaran layanan ekosistem. Saat ini dia memimpin Unit Analisis Ekonomi dan Kebijakan di ICRAF Indonesia.

James M Roshetko adalah Senior Integrated Natural Resource Management Scientist di World Agroforestry Centre (ICRAF) dan Winrock International. Dia menjabat Kepala Unit Pohon dan Pasar ICRAF Asia Tenggara dengan 33 tahun pengalaman, termasuk 16 tahun di Indonesia dan 27 tahun di Asia Selatan dan Tenggara. Jim sekarang menjabat sebagai Pimpinan Tim Senior proyek Agroforestry and Forestry in Sulawesi: Linking Knowledge with Action yang didanai oleh CIDA. Minat penelitian dan pengembangannya berfokus pada sistem berbasis pohon yang dikelola petani skala kecil sebagai sistem pengelolaan pertanian dan sumber daya alam yang viabel dan berkontribusi secara nyata pada tujuan ekonomi lokal juga lingkungan secara global. 


\section{Abstrak}

Proyek Agroforestry and Forestry in Sulawesi: Linking Knowledge with Action (Proyek AgFor Sulawesi) diimplementasikan di tiga provinsi di Sulawesi, Indonesia (Sulawesi Selatan, Sulawesi Tenggara, dan Gorontalo) dari 2011 hingga 2016 untuk meningkatkan sistem mata pencaharian agroforestri dan kehutanan masyarakat pedesaan. Survei dasar yang dilaporkan dalam dokumen ini dilakukan untuk mendukung proyek AgFor Sulawesi ini. Tujuan utama survei dasar ini adalah mempelajari karakteristik umum mata pencaharian masyarakat, sistem pertanian setempat, dan sistem penggunaan lahan berdasarkan perspektif masyarakat. Penilaian dinamika penggunaan lahan, sistem pertanian, dan strategi mata pencaharian di dua kabupaten di Sulawesi Selatan dianggap penting untuk mendesain fase proyek selanjutnya. Studi dasar mata pencaharian membahas mata pencaharian di tingkat masyarakat dan rumah tangga.

Hasil diskusi kelompok pada ketiga tipologi desa menunjukkan ada perbedaan yang cukup jelas dalam opsi mata pencaharian, jenis tanaman pohon, dan pengelolaan pertanian. Pada Tipologi 1 yaitu desa berlahan terdegradasi dengan sistem tanaman tahunan (Kayu Loe dan Bonto Karaeng), ladang jagung meningkat secara signifikan selama 40 tahun terakhir; sebaliknya, ada penurunan signifikan pada luas perkebunan kemiri dan perkebunan lain. Penggunaan komoditas jagung mendorong para petani untuk mengelola lahan mereka secara intensif. Pada Tipologi 2 yaitu desa dengan sistem agroforestri (Pattaneteang dan Campaga), budi daya kopi dan cengkeh meningkat cukup signifikan selama 40 tahun terakhir, tetapi ada pengurangan dalam ladang jagung dan hutan. Para petani pada tipologi-tipologi ini sudah lama mempraktikkan sistem agroforestri kompleks (kopi, kakao, dan cengkeh). Pada Tipologi 3 yaitu desa dengan sistem berbasis kayu (Tugondeng dan Tana Towa), dinamika penggunaan lahannya berbeda. Di Tugondeng lahan perkebunan kelapa meningkat cukup signifikan selama 40 tahun terakhir hingga kini menjadi sumber daya alam utama. Di Tana Towa, nyaris semua opsi penggunaan lahan tetap sama selama 40 tahun terakhir karena adanya hukum adat yang kuat di desa itu untuk melindungi area hutan dari konversi/ perambahan. Sistem agroforestri di desa-desa ini mencerminkan sistem pada Tipologi 2, yang diikuti dengan perkembangan perkebunan kayu rakyat (petani skala kecil) yang turut mendukung mata pencaharian masyarakat.

Dari hasil survei rumah tangga disimpulkan bahwa pendapatan total per tahun per rumah tangga untuk para petani pada Tipologi 1 lebih rendah dibandingkan dengan Tipologi 2 dan 3. Sumber pendapatan utama untuk para petani pada Tipologi 1 adalah ladang jagung dan kiriman uang; para petani Tipologi 2 tergantung pada produk agroforestri mereka, dan para petani Tipologi 3 didukung oleh perkebunan kelapa dan kegiatan wiraswasta. Pendapatan per kapita harian para petani dalam area Tipologi 1 berada di bawah garis kemiskinan internasional.

Kata kunci: Proyek AgFor Sulawesi, Sulawesi Selatan, dinamika penggunaan lahan, mata pencaharian, pendapatan, kopi, kakao, cengkeh, agroforestri 


\section{Ucapan terima kasih}

Pendanaan utama proyek AgFor Sulawesi ini berasal dari Canadian International Development Agency (CIDA) dan dukungan ini amat dihargai.

Para penulis ingin berterima kasih kepada Yana Buana, Adriyanto Pratama, M Erik Kurniawan, Kusdianawati, Badri Dwi Meyldi, dan Syamsidar atas kontribusi mereka dalam wawancara rumah tangga dan fasilitasi diskusi kelompok. Terima kasih kepada Elok Mulyoutami, Endri Martini, dan Pratiknyo Purnomosidhi untuk diskusi bermanfaat selama kegiatan di lapangan. Para penulis juga sangat menghargai dukungan penuh dari Tim Bantaeng Proyek AgFor Sulawesi serta dari para kepala desa di Kabupaten Bantaeng dan Bulukumba. Ucapan terima kasih terutama ditujukan kepada semua penduduk desa dan petani di Sulawesi Selatan yang berpartisipasi dalam diskusi, wawancara, dan pengamatan lapangan. 



\section{Daftar isi}

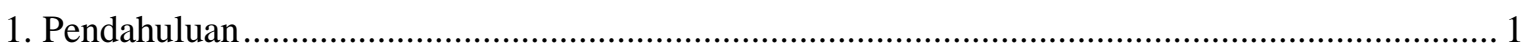

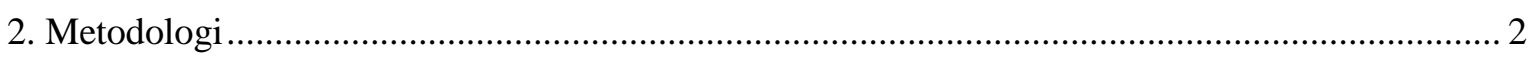

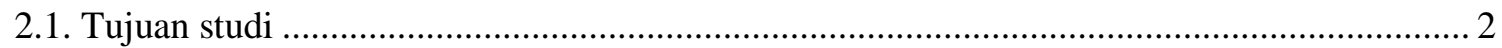

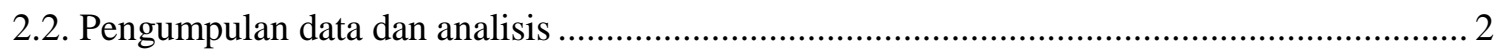

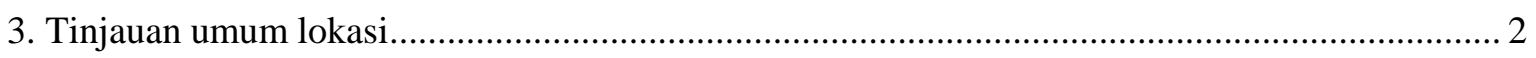

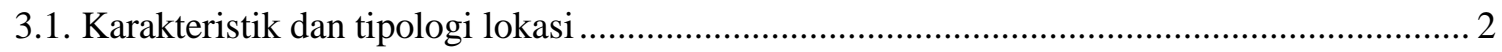

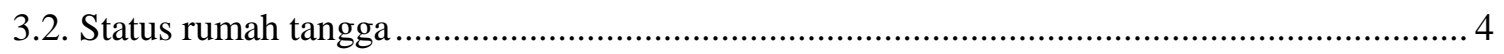

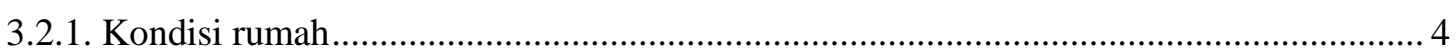

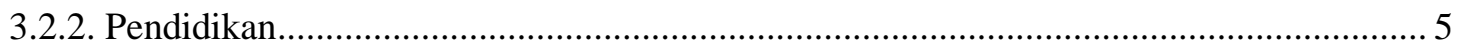

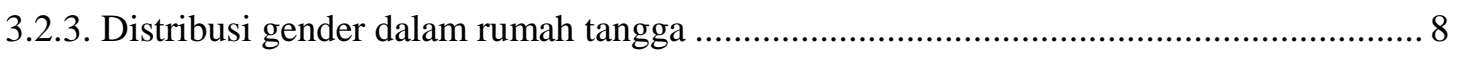

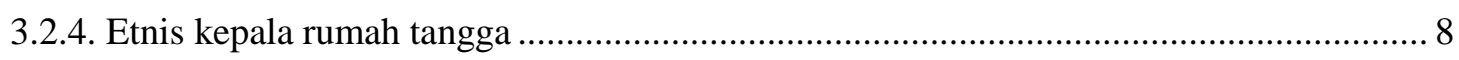

4. Sejarah desa dan dinamika penggunaan lahan di Sulawesi Selatan ............................................... 9

4.1. Perspektif masyarakat mengenai sejarah desa dan dinamika penggunaan lahan di

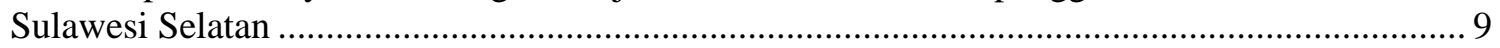

4.1.1. Tipologi 1 (desa berlahan terdegradasi dengan tanaman tahunan sebagai sistem

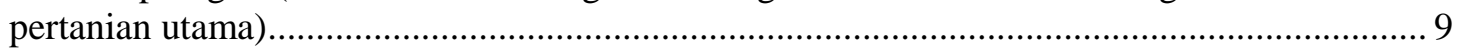

4.1.2. Tipologi 2 (desa dengan sistem agroforestri) ............................................................... 12

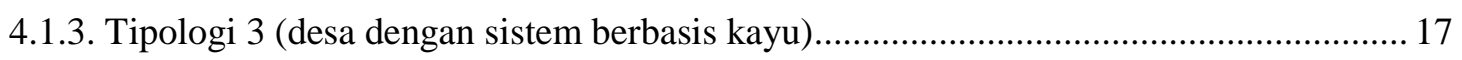

4.2. Perspektif rumah tangga mengenai karakteristik lahan ........................................................ 20

4.2.1. Karakteristik lahan di Sulawesi Selatan...................................................................... 20

4.2.2. Status kepemilikan dan penggunaan lahan di Sulawesi Selatan ..................................... 24

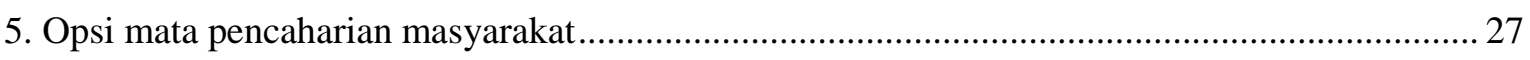

5.1. Tipologi 1 (desa berlahan terdegradasi dengan tanaman tahunan sebagai sistem

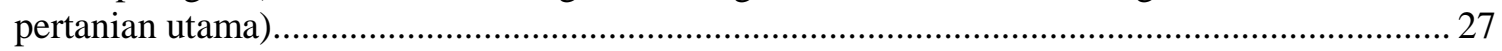

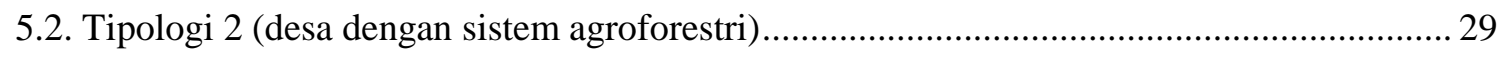

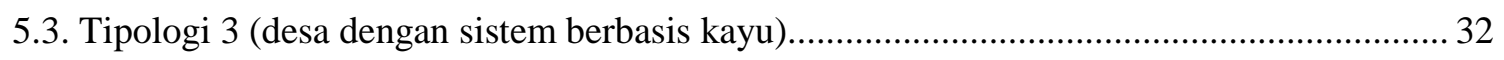

5.4. Indikator penting mata pencaharian berdasarkan survei rumah tangga ................................. 34

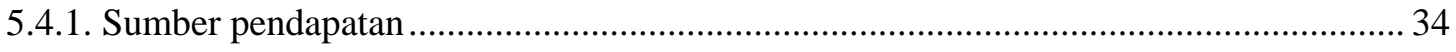

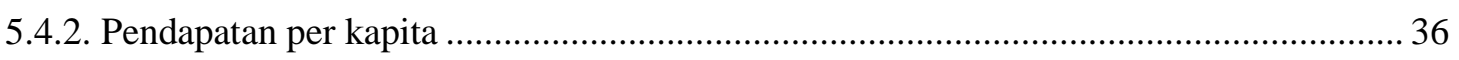

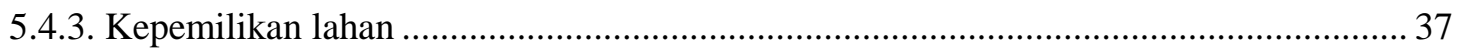

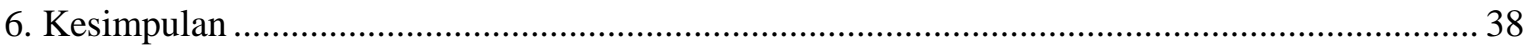

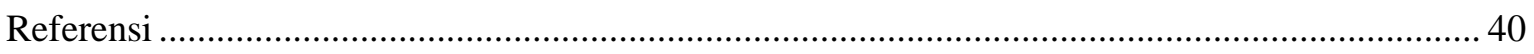




\section{Daftar Gambar}

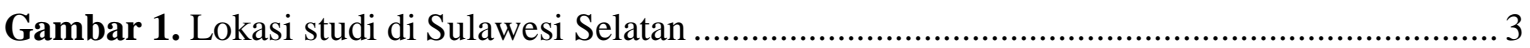

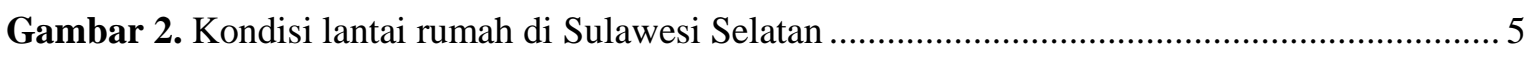

Gambar 3. Sumber penerangan rumah di Sulawesi Selatan ........................................................ 5

Gambar 4. Tingkat pendidikan kepala rumah tangga dan istri di Sulawesi Selatan......................... 6

Gambar 5. Distribusi pendidikan anak di Sulawesi Selatan ........................................................ 7

Gambar 6. Distribusi gender dalam rumah tangga di Sulawesi Selatan............................................ 8

Gambar 7. Etnis kepala rumah tangga di Sulawesi Selatan ......................................................... 8

Gambar 8. Penggunaan lahan terkini di Desa Kayu Loe berdasarkan perspektif masyarakat ........ 10

Gambar 9. Dinamika penggunaan lahan di Desa Kayu Loe berdasarkan perspektif masyarakat

Gambar 10. Penggunaan lahan terkini di Desa Bonto Karaeng berdasarkan perspektif masyarakat.

Gambar 11. Dinamika penggunaan lahan in Bonto Karaeng berdasarkan perspektif masyarakat. 12

Gambar 12. Penggunaan lahan terkini di Desa Pattaneteang berdasarkan perspektif masyarakat. 13

Gambar 13. Dinamika penggunaan lahan di Pattaneteang berdasarkan perspektif masyarakat..... 13

Gambar 14. Penggunaan lahan terkini di Desa Campaga berdasarkan perspektif masyarakat ...... 14

Gambar 15. Dinamika penggunaan lahan di Campaga berdasarkan perspektif masyarakat .......... 14

Gambar 16. Penggunaan lahan terkini di Desa Borongrappoa berdasarkan perspektif

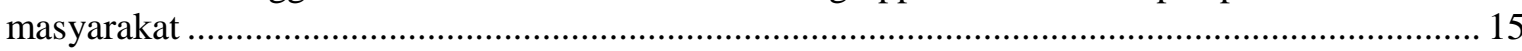

Gambar 17. Dinamika penggunaan lahan di Borongrappoa berdasarkan perspektif masyarakat .. 16

Gambar 18. Penggunaan lahan terkini di Desa Balangpesoang berdasarkan perspektif masyarakat

Gambar 19. Dinamika penggunaan lahan di Balangpesoang berdasarkan perspektif masyarakat

Gambar 20. Penggunaan lahan terkini di Desa Tugondeng berdasarkan perspektif masyarakat ... 18

Gambar 21. Dinamika penggunaan lahan di Tugondeng berdasarkan perspektif masyarakat....... 18

Gambar 22. Penggunaan lahan terkini di Tana Towa berdasarkan perspektif masyarakat ............ 19

Gambar 23. Dinamika penggunaan lahan di Tana Towa berdasarkan perspektif masyarakat....... 19

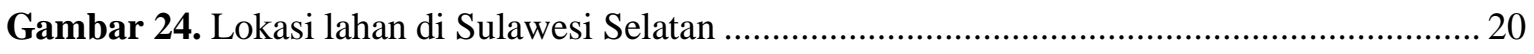

Gambar 25. Waktu berjalan kaki dari rumah menuju ke lahan di Sulawesi Selatan....................... 21

Gambar 26. Permukaan lahan di Sulawesi Selatan .................................................................... 21

Gambar 27. Status pengelolaan lahan di Sulawesi Selatan ........................................................... 22

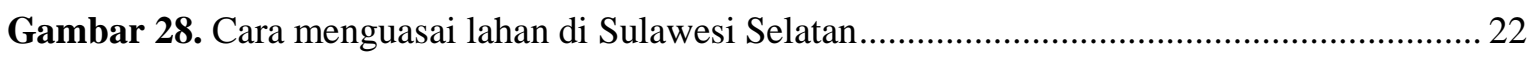

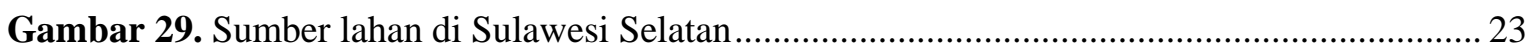

Gambar 30. Tahun penguasaan lahan di Sulawesi Selatan ........................................................... 23

Gambar 31. Status kepemilikan lahan terkini di Sulawesi Selatan ................................................ 24

Gambar 32. Pola penggunaan lahan sebelum saat ini di Sulawesi Selatan ..................................... 25

Gambar 33. Pola penggunaan lahan saat ini di Sulawesi Selatan ................................................. 25 
Gambar 34. Penggunaan lahan sebelum dikuasai di Sulawesi Selatan .......................................... 26

Gambar 35. Penggunaan lahan satu tahun setelah dikuasai di Sulawesi Selatan ............................ 26

Gambar 36. Opsi mata pencaharian terkini di Kayu Loe dan Bonto Karaeng berdasarkan

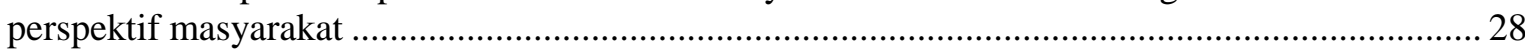

Gambar 37. Opsi mata pencaharian terkini di Pattaneteang dan Campaga berdasarkan perspektif masyarakat 30

Gambar 38. Opsi mata pencaharian terkini di Borongrappoa dan Balangpesoang berdasarkan perspektif masyarakat 32

Gambar 39. Opsi mata pencaharian terkini di Tugondeng dan Tana Towa berdasarkan perspektif masyarakat 33

Gambar 40. Sumber pendapatan di Sulawesi Selatan pada 2012. 36

Gambar 41. Rata-rata pendapatan per kapita per hari masyarakat di Sulawesi Selatan

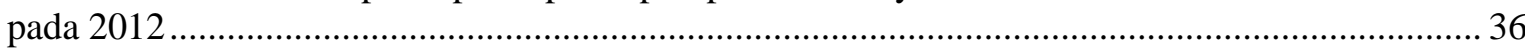

Gambar 42. Distribusi kepemilikan lahan rata-rata per rumah tangga di Sulawesi Selatan .37 


\section{Daftar Tabel}

Tabel 1. Tipologi desa dan detail FGD dan survei rumah tangga di Sulawesi Selatan ..................... 4

Tabel 2. Tingkat pendidikan kepala rumah tangga di Sulawesi Selatan .......................................... 6

Tabel 3. Distribusi pendidikan anak di Sulawesi Selatan................................................................. 7

Tabel 4. Distribusi rata-rata jumlah tanaman per hektar di Sulawesi Selatan .................................. 27

Tabel 5. Rata-rata pendapatan masyarakat berdasarkan sumber pendapatan di Sulawesi Selatan pada tahun 2012

Tabel 6. Distribusi luas penguasaan lahan rata-rata berdasarkan penggunaan lahan di Sulawesi Selatan 37 



\section{Pendahuluan}

Proyek Agroforestry and Forestry in Sulawesi: Linking Knowledge with Action (Proyek AgFor Sulawesi) sedang diimplementasikan di 3 provinsi di Pulau Sulawesi, Indonesia (Sulawesi Selatan, Sulawesi Tenggara, dan Gorontalo) dari 2011 hingga 2016. Hasil utama proyek ini adalah untuk meningkatkan sistem mata pencaharian agroforestri dan kehutanan masyarakat pedesaan di Sulawesi (Roshetko et al. 2012).

Tantangan utama dalam proyek ini adalah rendahnya keanekaragaman sistem mata pencaharian pedesaan, ketergantungan tinggi penduduk pada tanaman komoditas eksotis, dan kerentanan terhadap risiko (biologis dan pasar) yang terus berlanjut. Sistem agroforestri yang beragam pada lanskap yang dikelola dengan baik, dengan tingkat intensitas mulai dari sawah intensif hingga hutan alami, secara umum dianggap sebagai sistem yang lebih kokoh dan terhindar dari risiko. Oleh karena itu, Proyek ini bertujuan untuk menetapkan sistem tersebut di 3 provinsi di Sulawesi. Lebih jauh lagi, pengelolaan daerah aliran sungai (DAS) yang kurang optimal menyebabkan peningkatan erosi tanah, sedimentasi, longsor, dan banjir. Kedua, analisis mengindikasikan bahwa Sulawesi akan mengalami variasi yang substansial dalam kondisi atmosfer sekarang, berarti akan lebih memperburuk masalah DAS. Pengelolaan DAS yang ditingkatkan dan strategi adaptasi untuk petani setempat diperlukan untuk mengamankan mata pencaharian dan melindungi lingkungan. Juga harus ada insentif yang membantu pengembangan program jasa lingkungan. Ketiga, orangorang yang termarginalisasi tidak memiliki cukup hak atas tanah mereka dan memiliki sedikit kesadaran akan, atau akses pada, penghubung untuk sertifikasi atau klarifikasi status lahan. Hal ini melanggengkan kerentanan dan menghambat investasi. Serupa dengan itu, hak perempuan juga seringkali dipinggirkan atau diabaikan, mengindikasikan adanya kebutuhan khusus untuk peningkatan kesadaran dan pemberdayaan. Perambahan yang berlanjut ke dalam area hutan dilihat sebagai pendorong utama deforestasi dan menunjukkan gejala konflik yang lebih luas di antara masyarakat dengan pemerintah. Keempat, kapasitas tata kelola setempat lemah. Banyak kabupaten yang tidak siap menghadapi desentralisasi dan demokratisasi. Setelah 10 tahun, banyak kapasitas setempat yang sudah dikembangkan, tetapi pemerintahan mandiri masih dipahami lebih sebagai hak dan bukan tanggung jawab. Usaha pembangunan masih tidak memiliki visi jangka panjang penting yang cukup untuk mencapai keberlanjutan. Partisipasi masyarakat dalam perencanaan penggunaan lahan pemerintah masih jarang terjadi, sama halnya dengan insentif dan keuntungan relevan untuk masyarakat tersebut (Roshetko et al. 2012).

Survei dasar dilakukan untuk mendukung proyek ini. Salah satu tujuan utama survei ini adalah untuk mempelajari karakteristik umum tipe mata pencaharian di masyarakat, sistem pertanian setempat, dan sistem penggunaan lahan yang ada di area tersebut berdasarkan perspektif masyarakat. Penilaian dinamika penggunaan lahan, sistem pertanian, dan strategi mata pencaharian di dalam 2 kabupaten terpilih di Provinsi Sulawesi Selatan dirasakan sangat penting untuk mendesain fase proyek selanjutnya dan juga untuk mendesain strategi yang dipilih dan viabilitas strategi itu pada kondisi setempat. Dua analisis unit digunakan dalam studi dasar mata pencaharian---tingkat masyarakat dan rumah tangga. Studi ini memberikan dasar perspektif kepada masyarakat mengenai dinamika penggunaan lahan, sistem pertanian, strategi mata pencaharian, dan data mengenai kegiatan tingkat rumah tangga yang lebih terperinci di Sulawesi Selatan. 


\section{Metodologi}

\subsection{Tujuan studi}

Tujuan utama studi ini adalah:

- Mengidentifikasi karakteristik umum mata pencaharian, sistem pertanian, dan sistem penggunaan lahan lain di area tersebut berdasarkan perspektif masyarakat.

- Melakukan identifikasi tersebut menggunakan survei rumah tangga.

\subsection{Pengumpulan data dan analisis}

Data didapatkan dengan diskusi kelompok terarah (FGD) di tiap desa sampel di 2 kabupaten di Provinsi Sulawesi Selatan. FGD berjalan sepanjang hari dengan diikuti oleh rata-rata delapan petani dalam tiap kelompok. Para partisipan terdiri dari anggota desa yang paling memahami kondisi setempat. Topik diskusi berkisar antara demografik, sejarah, sistem penggunaan lahan, sumber mata pencaharian, dan praktik pengelolaan lahan desa.

Informasi tingkat rumah tangga dikumpulkan dari 30 rumah tangga menggunakan stratifikasi acak dari 4 desa di Sulawesi Selatan (Tabel 1). Setiap kali memungkinkan, suami dan istri dari tiap rumah tangga diwawancarai bersama-sama. Rinciannya dijelaskan dalam bagian selanjutnya.

\section{Tinjauan umum lokasi}

\subsection{Karakteristik dan tipologi lokasi}

Provinsi Sulawesi Selatan berlokasi di bagian selatan Pulau Sulawesi dan meliputi 20 kabupaten dan 3 kotamadya dengan area total $45764 \mathrm{~km}^{2}$. Lebih dari 57\% area provinsi ini berhutan, dengan area yang tersisa terpakai untuk padi sawah (9\%), lahan basah (>10\%), dan lahan subur (mendekati 10\%). Provinsi ini terkenal sebagai produsen pertama padi dan tanaman pangan lain, termasuk jagung, singkong, ubi jalar, dan kacang di bagian timur Indonesia. Tanaman perkebunan penting dari Sulawesi Selatan adalah kakao, kelapa, cengkeh, dan kopi; budi daya dilakukan terutama oleh petani skala kecil. Kabupaten Bantaeng dan Bulukumba dipilih sebagai lokasi Proyek Sulawesi AgFor (Gambar 1).

Kedua kabupaten berlokasi di lahan bergunung-gunung sejauh sekitar 150 km dari Makassar. Kabupaten Bulukumba memiliki luas 1 154,7 km² dan penduduk sejumlah 394757 jiwa pada 2010 (BPS, 2010). Kabupaten yang bersebelahan dengan Bulukumba adalah Bantaeng yang berukuran lebih kecil, meliputi 395,83 km² dengan populasi sebanyak 170057 jiwa pada 2010. Pada 2007, Kabupaten Bantaeng dan Bulukumba adalah, secara berurutan, produsen jagung kedua dan kelima tertinggi untuk tanaman pangan (kabupaten lain meliputi Gowa, Jeneponto, dan Bone). Kedua kabupaten ini juga produsen besar padi. Sekalipun Bantaeng bukan produsen terbesar, produksi kabupaten ini masih jauh berada di atas rata-rata untuk Sulawesi Selatan (5,01 dibandingkan 
dengan 4,7), sementara Bulukumba sedikit lebih rendah daripada rata-rata $(4,68)$ (BPS Sulawesi Selatan 2008).

Pada 2010, produksi kakao di Kabupaten Bantaeng dan Bulukumba meliputi 5377 dan 7456 ha secara berurutan; Bulukumba menghasilkan 4626 ton dan Bantaeng menghasilkan 2157 ton kakao.

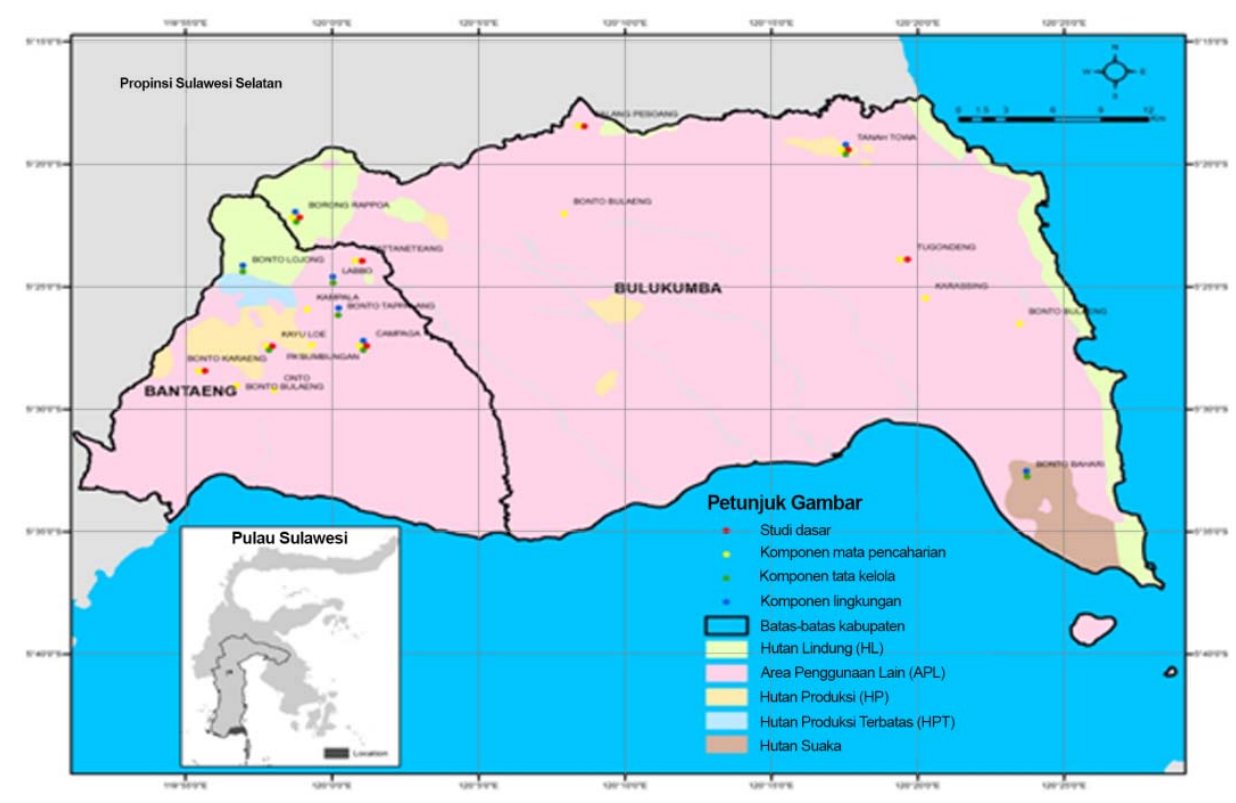

Gambar 1. Lokasi studi di Sulawesi Selatan

Produksi kelapa terutama dihasilkan oleh petani skala kecil dalam sistem kebun campur (lebih dari 111526 ha) dan perkebunan swasta dengan jangkauan lebih sedikit (1431 ha). Dari 83724 ton yang diproduksi pada 2010 di Sulawesi Selatan, Bulukumba dan Bantaeng menghasilkan 0,9\% dan 2,6\% dari total produksi tersebut, secara berurutan.

Produksi cengkeh memiliki situasi yang mirip, menggunakan lahan sekitar 44524 ha. Dari 16385 ton cengkeh yang diproduksi pada 2010, Bulukumba dan Bantaeng menghasilkan 5,2\% dan 1,9\% dari total produksi, secara berurutan.

Dari produksi kopi total pada 2010 di Sulawesi Selatan mencapai 36554 ton, Bulukumba menghasilkan 11,3\% dan Bantaeng menghasilkan 4,38\%. Area total produksi kopi di Sulawesi Selatan yang dikelola oleh petani skala kecil adalah 70412 ha (3 800 ha di Bantaeng dan 5179 ha di Bulukumba).

Untuk mendapatkan karakteristik umum tiap lokasi Proyek AgFor Sulawesi di Sulawesi Selatan, dikembangkan tipologi kelompok selama kunjungan lapangan, yang dilakukan setelah pertemuan awal diadakan di Makassar pada 25 Januari 2012. Tipologi-tipologi ini didasarkan pada kondisi fisik yang mengarah ke kegiatan penggunaan lahan utama dan praktik pertanian yang berbeda-beda di tiap area, serta mempertimbangkan status administratif. Daftar tipologi dijelaskan dalam Tabel 1. 
Tabel 1. Tipologi desa dan detail FGD dan survei rumah tangga di Sulawesi Selatan

\begin{tabular}{|c|c|c|c|c|c|}
\hline Tipologi desa & $\begin{array}{l}\text { Lahan } \\
\text { terdegradasi, } \\
\text { sistem tanaman } \\
\text { tahunan }\end{array}$ & $\begin{array}{l}\text { Sistem } \\
\text { agroforestri }\end{array}$ & Sistem agroforestri & $\begin{array}{l}\text { Sistem } \\
\text { berbasis kayu }\end{array}$ & $\begin{array}{l}\text { Responden } \\
\text { kelompok/rumah } \\
\text { tangga total }\end{array}$ \\
\hline & 1 & 2 & 2 & 3 & \\
\hline Kabupaten & Bantaeng & Bantaeng & Bulukumba & Bulukumba & \\
\hline Desa & $\begin{array}{l}\text { Onto, Kayu Loe, } \\
\text { Bonto Bulaeng, } \\
\text { Bonto Karaeng, } \\
\text { Pabumbungan }\end{array}$ & $\begin{array}{l}\text { Campaga, } \\
\text { Labbo, } \\
\text { Pattaneteang, } \\
\text { Kampala }\end{array}$ & $\begin{array}{l}\text { Borongrappoa, } \\
\text { Balangpesoang, } \\
\text { Batu Karopa, } \\
\text { Kahayya, Bangkeng } \\
\text { Bukit }\end{array}$ & $\begin{array}{l}\text { Karassing, } \\
\text { Tugondeng, } \\
\text { Tana Towa, } \\
\text { Tanah Beru }\end{array}$ & \\
\hline FGD & $\begin{array}{l}\text { Kayu Loe } \\
\text { Bonto Karaeng }\end{array}$ & $\begin{array}{l}\text { Pattaneteang } \\
\text { Campaga }\end{array}$ & $\begin{array}{l}\text { Borongrappoa } \\
\text { Balangpesoang }\end{array}$ & $\begin{array}{l}\text { Tugondeng } \\
\text { Tana Towa }\end{array}$ & 8 kelompok \\
\hline $\begin{array}{l}\text { Survei rumah } \\
\text { tangga }\end{array}$ & Kayu Loe & Campaga & Balangpesoang & Tugondeng & 120 rumah tangga \\
\hline
\end{tabular}

\subsection{Status rumah tangga}

\subsubsection{Kondisi rumah}

Kondisi rumah para petani dapat digunakan untuk memperkirakan kesejahteraan mereka (BPS 2009). Kami menilai kondisi rumah menggunakan 4 variabel: tipe dinding, atap, lantai, dan ketersediaan penerangan. Kondisi rumah para petani yang bekerja di lahan terdegradasi dengan sistem tanaman semusim (selanjutnya dirujuk sebagai Tipologi 1) adalah paling buruk dibandingkan dengan rumah-rumah yang dimiliki oleh para petani sistem agroforestri (Tipologi 2) dan berbasis kayu (Tipologi 3) dengan kondisi hampir sama.

Untuk Tipologi 1, kebanyakan lantai terbuat dari kayu (87\%) dan penerangan tersedia dari lampu tempel (57\%) dan listrik tenaga air (27\%). Untuk Tipologi 2, sebagian besar lantai terbuat dari kayu (40-77\%) dan semen (23-43\%) dan penerangan tersedia dari jaringan listrik PLN (93\%). Untuk Tipologi 3, sebagian besar lantai terbuat dari kayu (47\%) dan keramik (33\%). Penerangan juga tersedia dari jaringan listrik PLN (93\%) (Gambar 2 dan 3). 


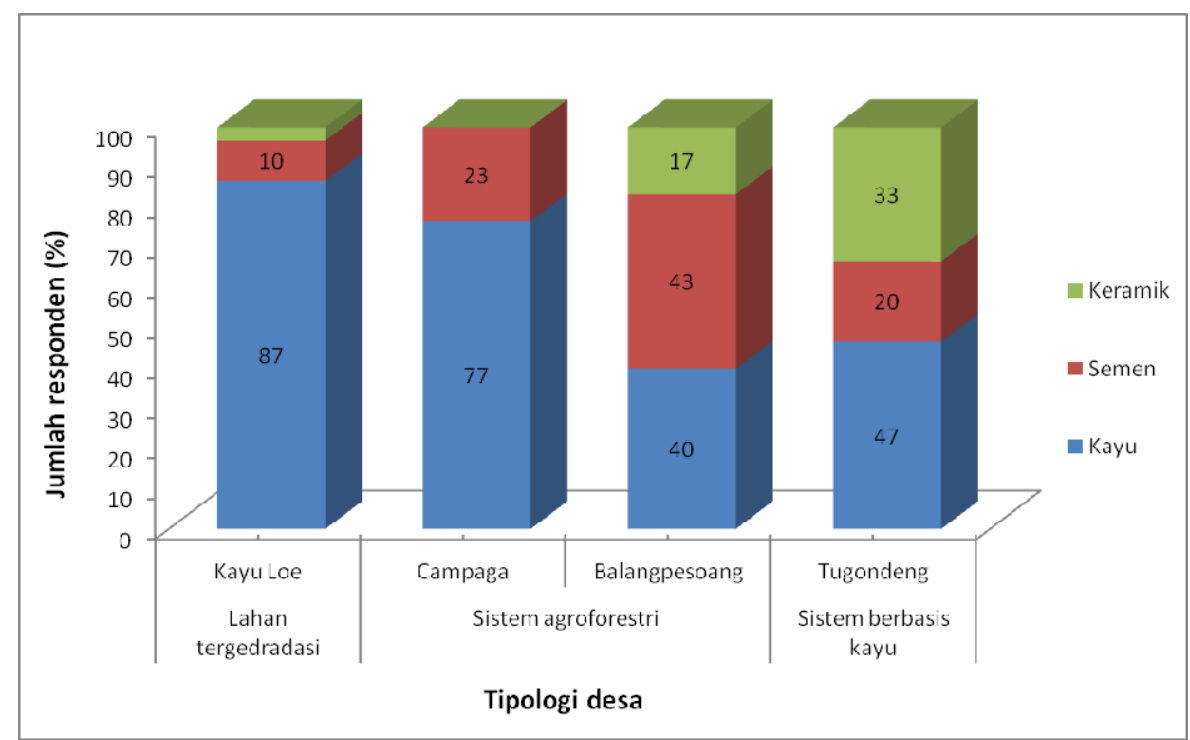

Gambar 2. Kondisi lantai rumah di Sulawesi Selatan

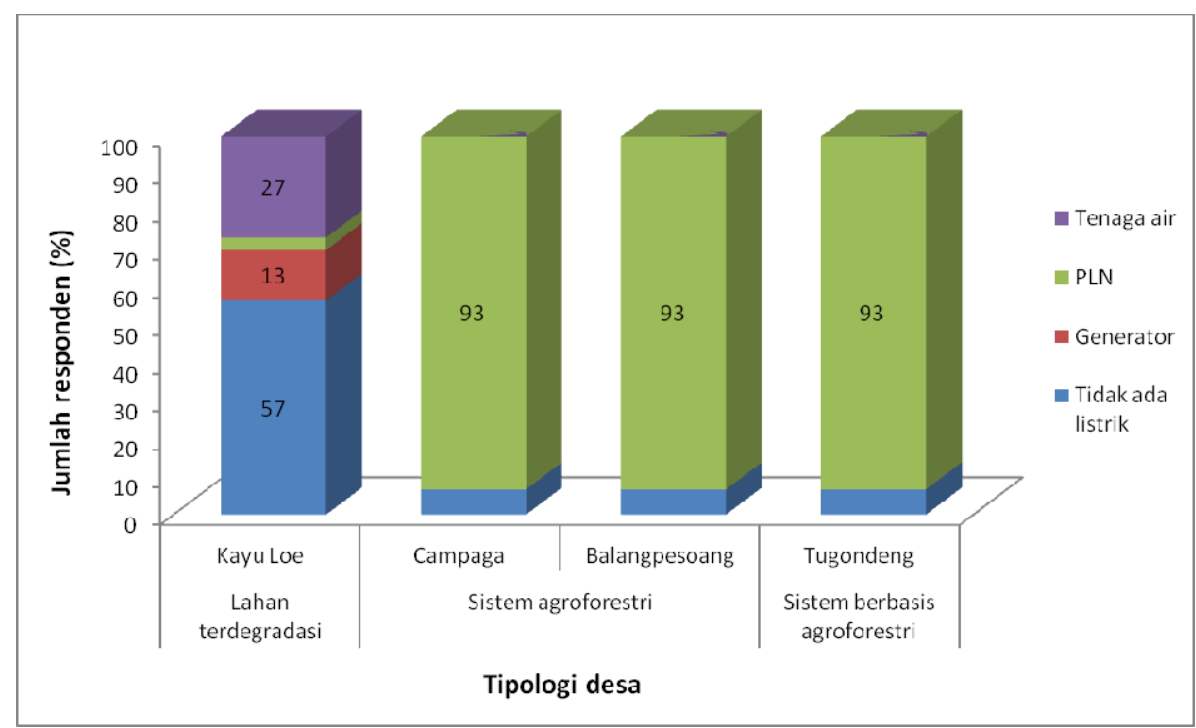

Gambar 3. Sumber penerangan rumah di Sulawesi Selatan

\subsubsection{Pendidikan}

Tingkat pendidikan untuk para petani Tipologi 1 sangat rendah, sementara tingkat pendidikan untuk kedua tipologi lain hampir sama. Pencapaian pendidikan perempuan sedikit lebih rendah daripada laki-laki. Namun, hasil analisis statistik menunjukkan tidak ada perbedaan signifikan dalam tingkat pendidikan antara laki-laki dan perempuan di semua lokasi.

Sebagian besar responden di Sulawesi Selatan, termasuk para suami dan istri, memiliki tingkat pendidikan sedang (Tabel 2 dan Gambar 4). Rata-rata lama pendidikan untuk para petani Tipologi 1 sangat rendah mencapai 1,29 tahun untuk laki-laki dan 1 tahun untuk perempuan. Tipologi ini juga memiliki tingkat buta huruf tertinggi (61\% untuk laki-laki dan 79\% untuk perempuan). Ratarata lama pendidikan pada petani Tipologi 2 adalah 5,2-5,7 tahun untuk laki-laki dan 6,0-6,2 tahun 
untuk perempuan. Petani Tipologi 3 memiliki rata-rata lama pendidikan tertinggi 9 tahun untuk laki-laki dan 8.9 tahun untuk perempuan. Namun, hasil analisis data menggunakan "uji $t$ " menunjukkan tidak ada perbedaan signifikan pada tingkat pendidikan antara laki-laki dan perempuan di semua lokasi.

Tabel 2. Tingkat pendidikan kepala rumah tangga di Sulawesi Selatan

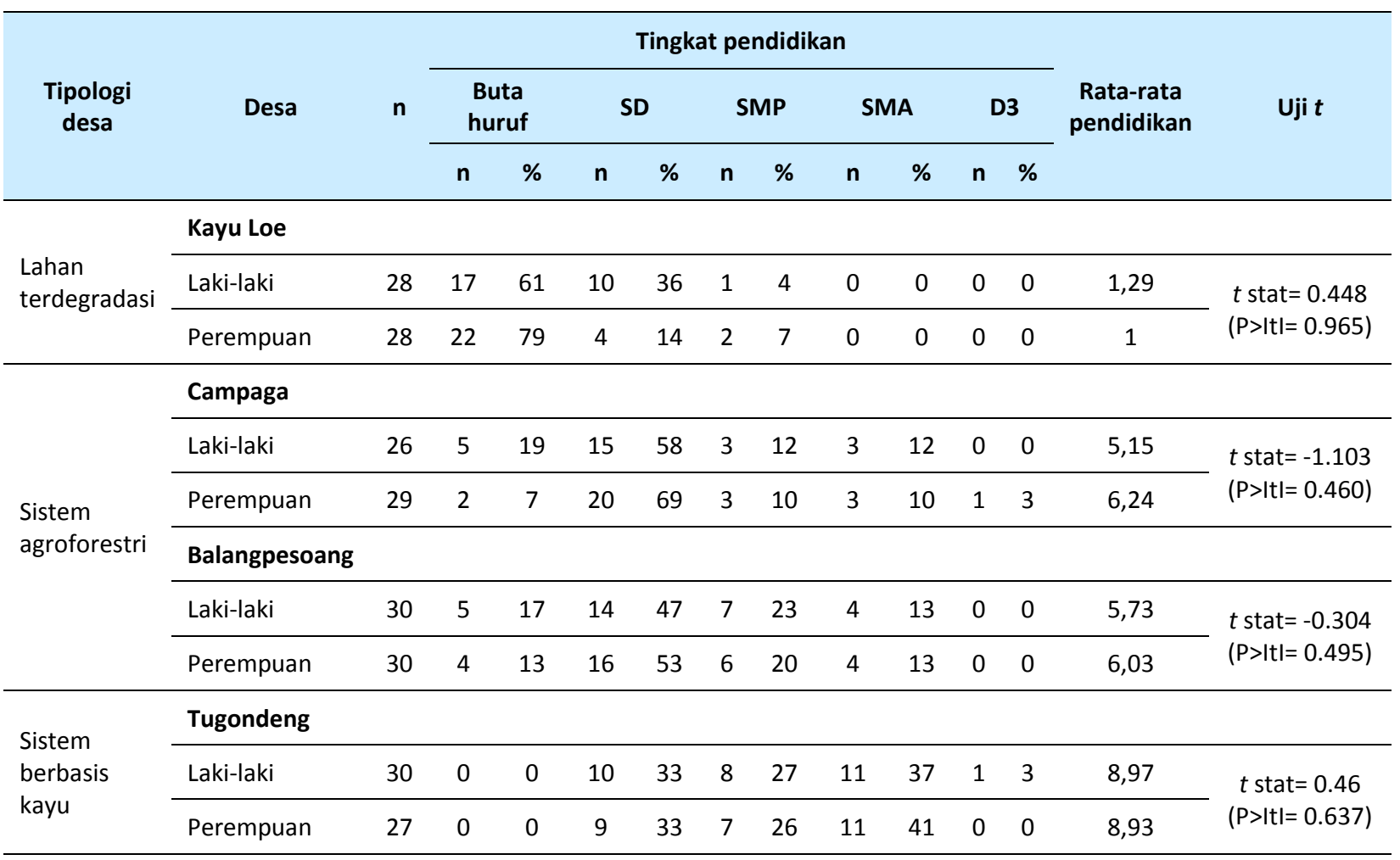

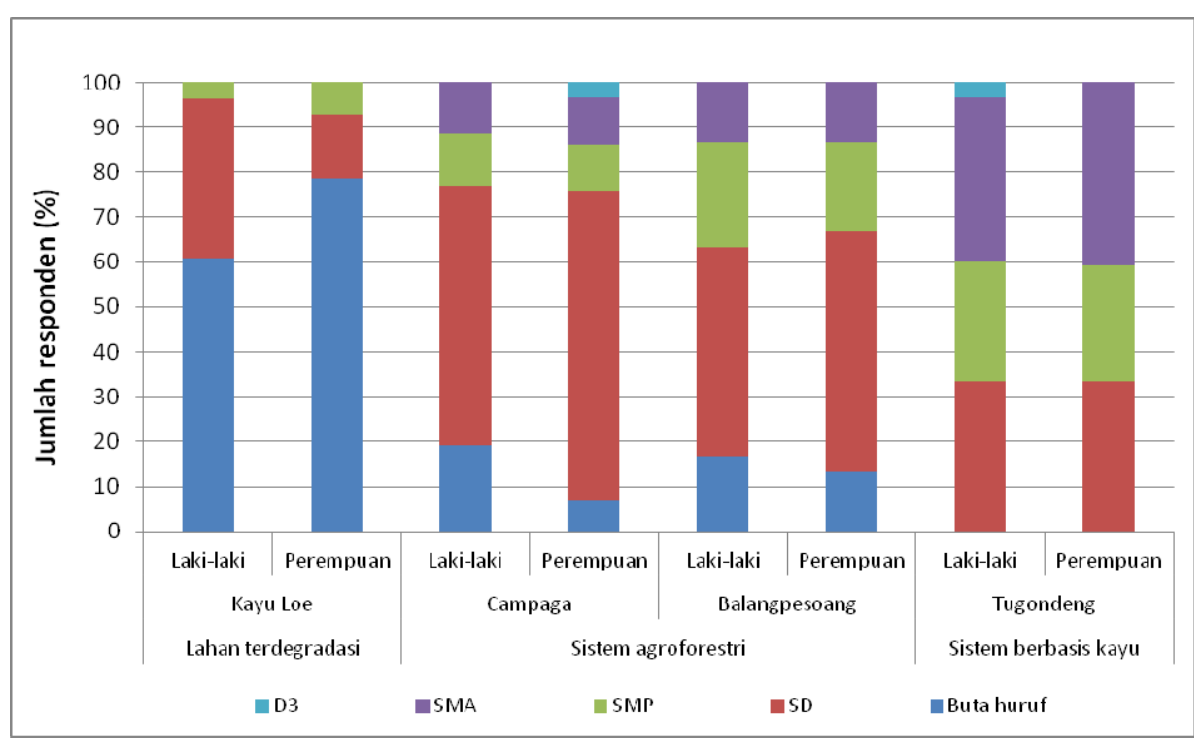

Gambar 4. Tingkat pendidikan kepala rumah tangga dan istri di Sulawesi Selatan

Kami juga menghitung distribusi pendidikan dari anak-anak responden di setiap tipologi (Tabel 3 dan Gambar 5). Rata-rata pendidikan pada anak petani Tipologi 1 sangat rendah yaitu 3,3 tahun 
untuk anak laki-laki dan 3,2 tahun untuk anak perempuan. Untuk petani Tipologi 2 adalah 6,6-8,2 tahun untuk anak laki-laki dan 7,00-7,40 tahun untuk anak perempuan, dan untuk Tipologi 3 adalah 7,7 untuk anak laki-laki dan 7,1 tahun untuk anak perempuan. Namun, hasil analisis data menggunakan uji $t$ menunjukkan tidak ada perbedaan signifikan antara tingkat pendidikan anak laki-laki dan perempuan di semua lokasi.

Tabel 3. Distribusi pendidikan anak di Sulawesi Selatan

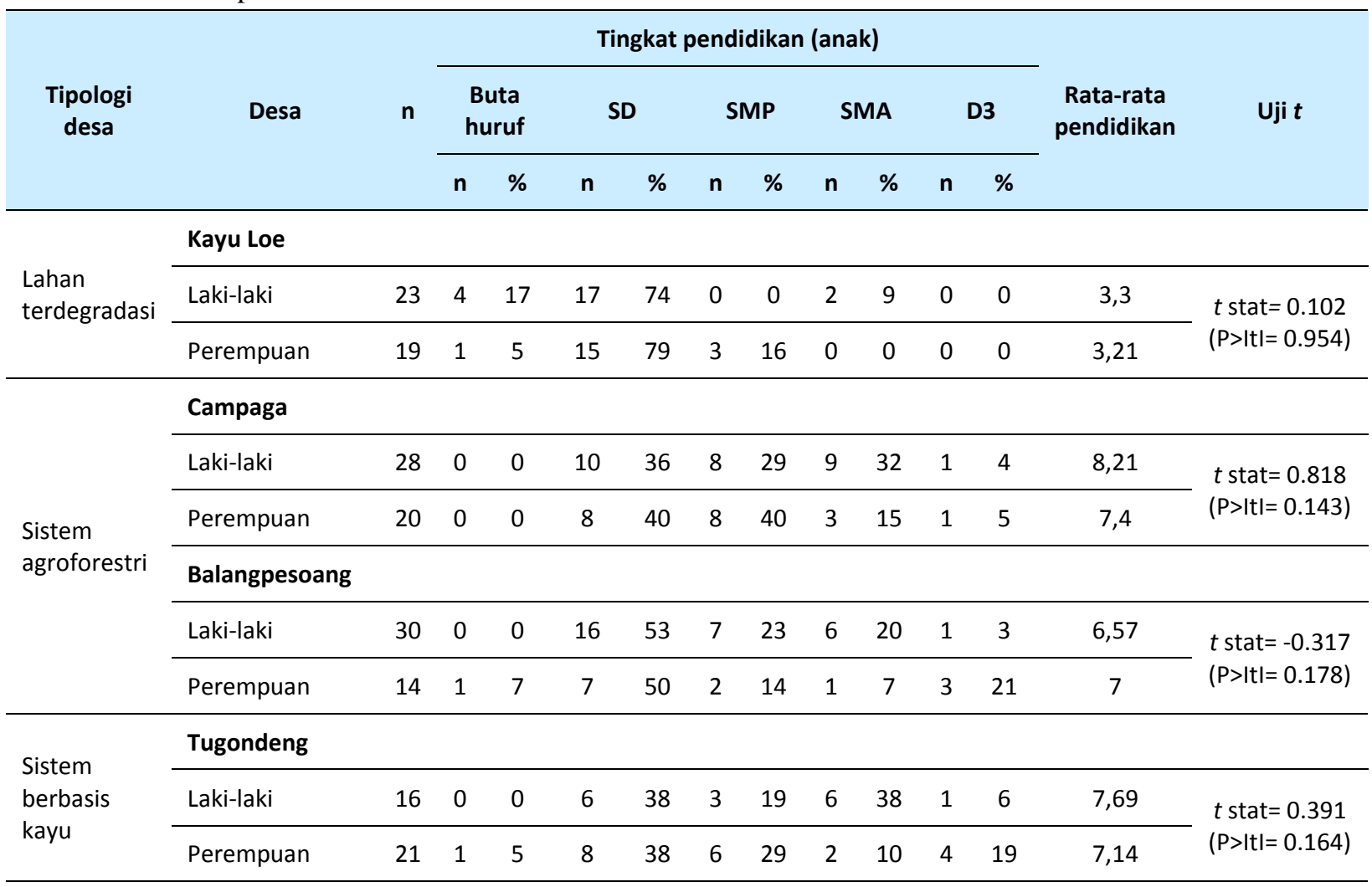

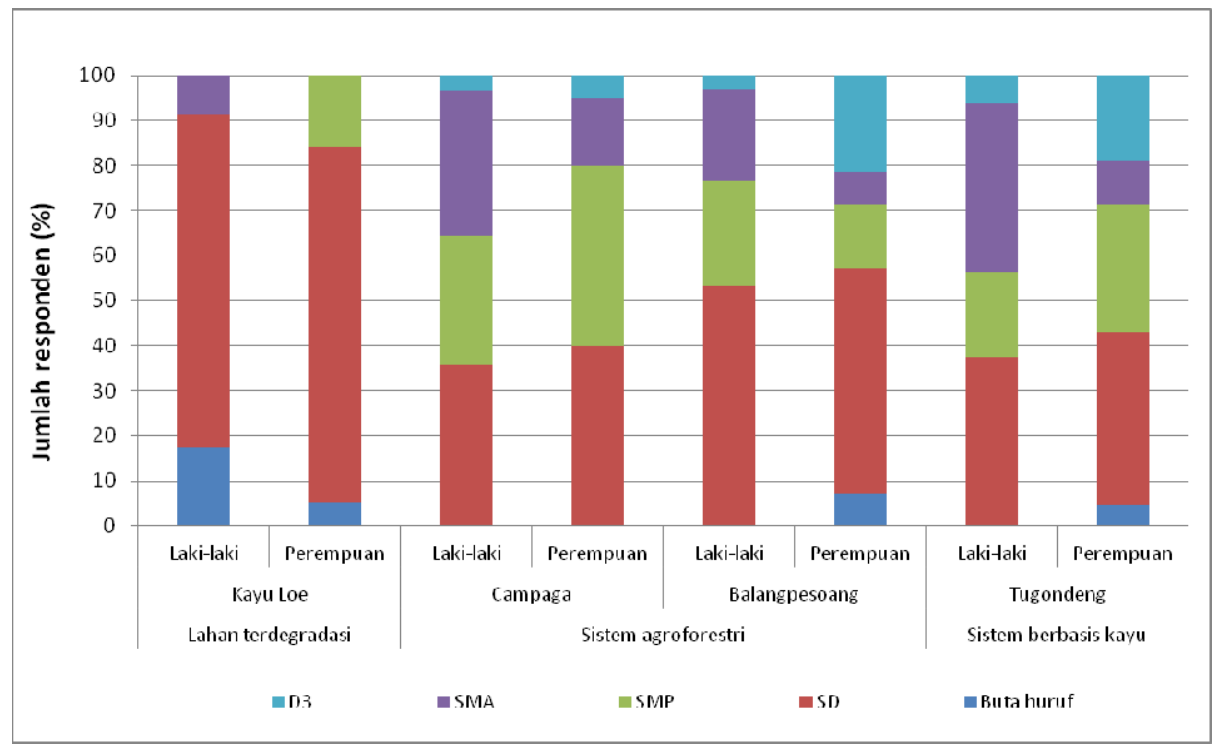

Gambar 5. Distribusi pendidikan anak di Sulawesi Selatan 


\subsubsection{Distribusi gender dalam rumah tangga}

Distribusi gender dalam ketiga tipologi relatif sama sekalipun Tipologi 1 dan 2 memiliki jenis kelamin laki-laki lebih banyak daripada perempuan. Keadaan ini berlawanan dengan Tipologi 3 (Gambar 6).

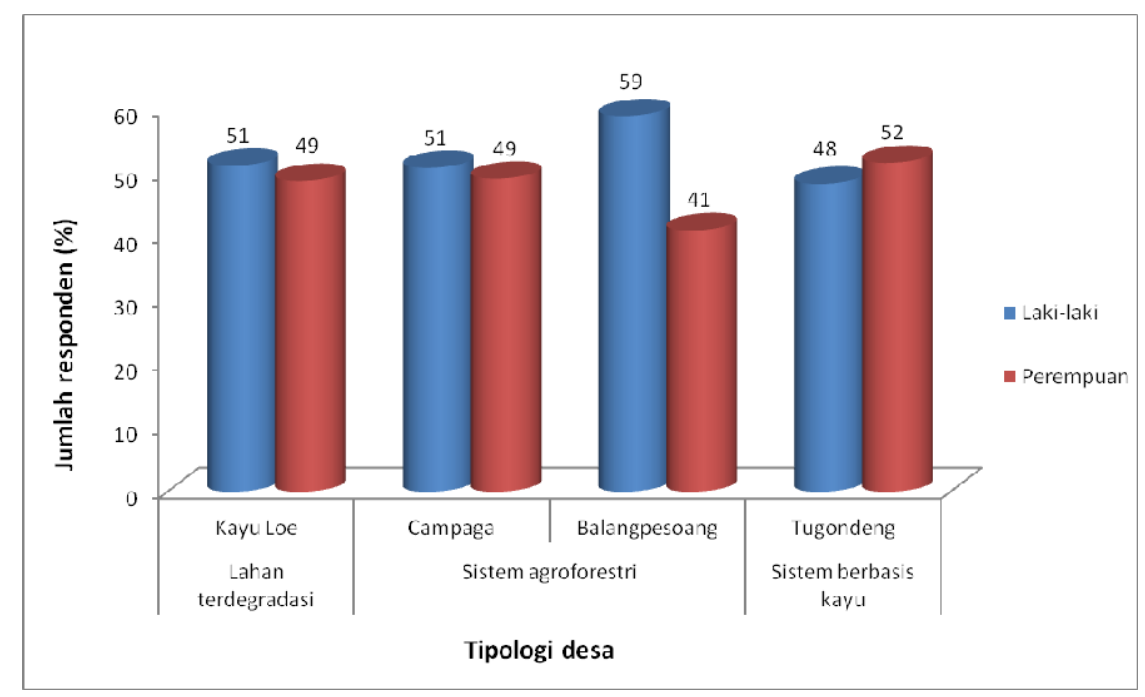

Gambar 6. Distribusi gender dalam rumah tangga di Sulawesi Selatan

\subsubsection{Etnis kepala rumah tangga}

Suku Makassar mendominasi di ketiga tipologi tetapi di Balangpesoang suku Bugis lebih dominan (Gambar 7).

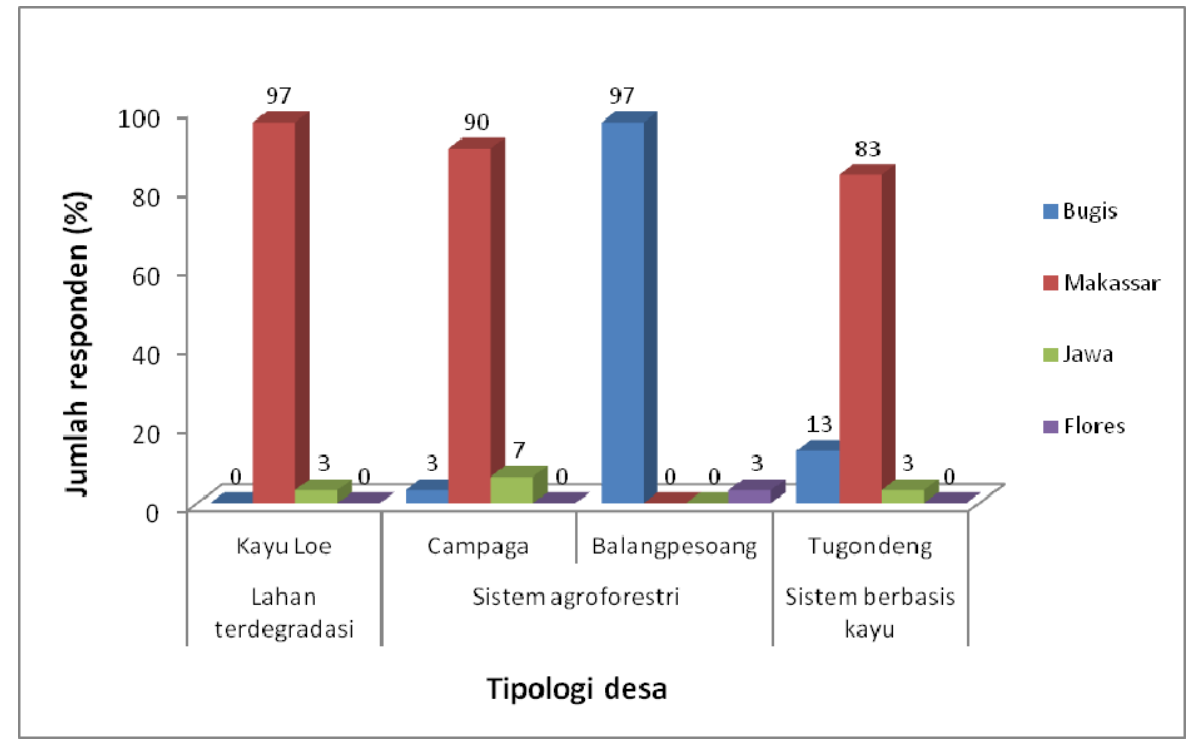

Gambar 7. Etnis kepala rumah tangga di Sulawesi Selatan 


\section{Sejarah desa dan dinamika penggunaan lahan di Sulawesi Selatan}

Bab ini mendiskusikan sejarah umum desa dan sistem penggunaan lahan utama. Jagung, padi, dan produk berbasis pohon adalah hasil pertanian paling umum dalam semua tipologi. Jagung cukup dominan di Tipologi 1, sementara sistem agroforestri berbasis cengkeh, kopi, dan kakao lazim ditemukan pada Tipologi 2.

\subsection{Perspektif masyarakat mengenai sejarah desa dan dinamika penggunaan lahan di Sulawesi Selatan}

\subsubsection{Tipologi 1 (desa berlahan terdegradasi dengan tanaman tahunan sebagai sistem pertanian utama)}

Para petani pada tipologi ini sudah menanam tanaman selama bertahun-tahun sebagai kegiatan pertanian yang paling utama. Dulu padi ladang, jagung, dan kopi merupakan tanaman utama, tetapi mulai pada 1980-an, jagung hibrida menjadi pilihan lain yang menyebabkan konversi area hutan menjadi lahan pertanian.

\section{Kayu Loe}

Kayu Loe didirikan pada 1930-an oleh nenek moyang suku Makassar di desa itu. Awalnya, tanaman utama di daerah ini adalah jagung (sebagai makanan pokok), singkong, kopi (kopi lokal bernama kopi bugis atau kopi Bantaeng), kentang, ubi jalar, talas, dan padi ladang. Penggunaan lahan dipengaruhi sangat kuat oleh daerah tutupan hutan (hutan lindung dan hutan kemasyarakatan), jadi ladang jagung tidak ekstensif pada saat itu. Pada 1980 para petani mulai menanam kopi arabica dari Jember (Jawa), kemudian dilanjutkan dengan menanam jagung hibrida (nama lokal: jagung kuning) pada 1985. Karena lonjakan penanaman jagung hibrida, konversi area hutan menjadi ladang jagung meningkat dengan cepat.

Pada awal 1990-an, para petani juga menanam cengkeh menggunakan bibit dari Manado. Budi daya cengkeh sangat menarik karena keuntungan yang dihasilkan. Untuk mendukung para petani, pemerintah menyuplai 5000 bibit cengkeh, 45000 bibit suren, dan beragam jenis durian dan pohon kayu (bayang jawa, mahoni, jati putih, dan sengon) pada 2010 dan 2011. 


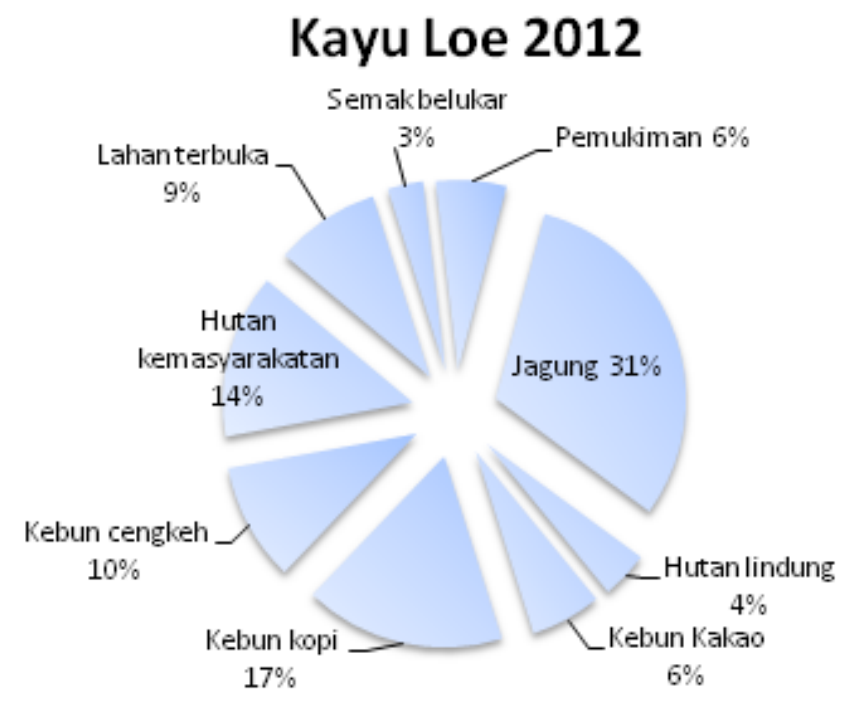

Gambar 8. Penggunaan lahan terkini di Desa Kayu Loe berdasarkan perspektif masyarakat

Sekarang jagung mendominasi penggunaan lahan di Kayu Loe karena lahan di daerah itu digunakan oleh sekitar 1/3 penduduk desa yang juga melanjutkan mendirikan kebun kopi, hutan kemasyarakatan, dan kebun cengkeh. Di dalam hutan kemasyarakatan, para petani menanam kemiri, mahoni, suren, sengon, kayu putih, dan jati putih (Gambar 8). Para petani juga menyebutkan kehadiran lahan terbuka (Bonto Rampan) yang sangat kritis disebabkan oleh praktik pertanian intensif yang tidak sesuai pada lahan miring.

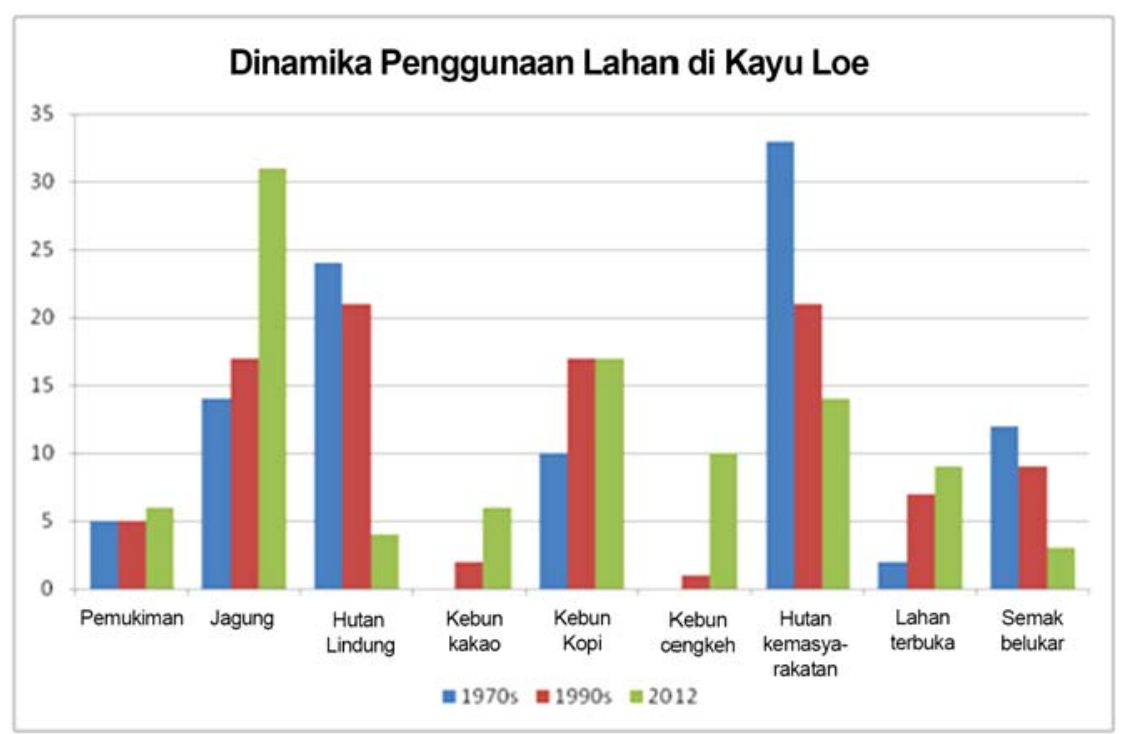

Gambar 9. Dinamika penggunaan lahan di Desa Kayu Loe berdasarkan perspektif masyarakat

Gambar 9 menunjukkan ladang jagung telah berkembang banyak selama 40 tahun terakhir. Tren ini berjalan bersamaan dengan penurunan area tutupan hutan yang signifikan---baik hutan kemasyarakatan dan hutan lindung. Situasi ini sesuai dengan peningkatan pesat jagung hibrida pada periode yang sama. 


\section{Bonto Karaeng}

Bonto Karaeng didirikan pada 1970-an ketika 7 rumah tangga suku Makassar dari Enrekang dan Bantaeng memutuskan untuk bermukim di Dusun Papasangan (Bonto Macini). Mereka menerapkan sistem ladang berpindah di sejumlah kecil hutan dan mengubah lahan hutan itu untuk budi daya jagung dan lahan pemukiman. Mata pencaharian mereka berasal dari budi daya jagung, mengumpulkan kemiri, dan memanen bambu, dan produk-produk tersebut dijual di Bantaeng. Pada awal 1990-an, para petani memulai penanaman padi dan jagung hibrida, yang tidak lama kemudian menjadi tanaman utama, dan masih hingga hari ini (Gambar 10).

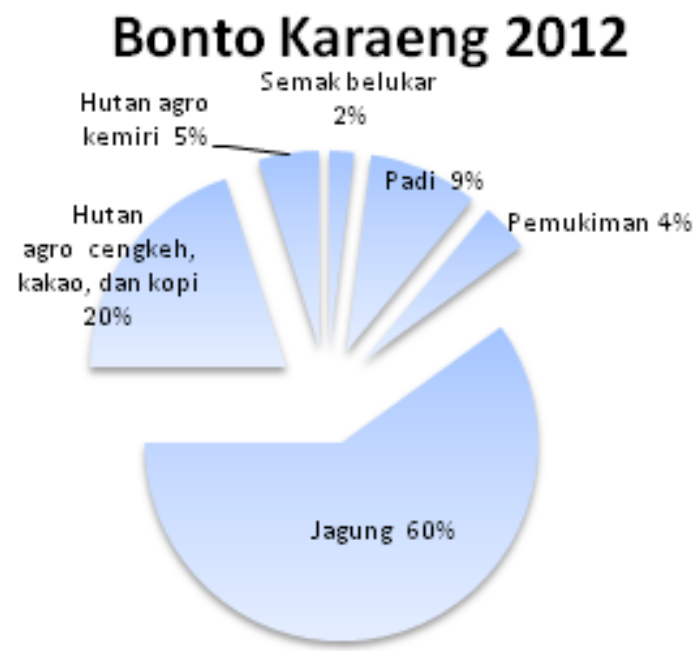

Gambar 10. Penggunaan lahan terkini di Desa Bonto Karaeng berdasarkan perspektif masyarakat

Kakao pertama kali diperkenalkan pada 1996. Pemerintah menyediakan 100000 bibit kakao pada tahun 2000 tetapi banyak bibit yang rusak akibat musim kering yang parah. Namun, para petani masih bisa mendapatkan penghasilan dari kakao yang tersisa, harga pada 2005 mencapai sekitar

Rp 10000 per kilogram ${ }^{1}$. Pada 2009, ketika harga cengkeh lebih mahal daripada kakao, minat para petani tergugah dan mereka membeli bibit dari Kabupaten Bulukumba. Pemerintah juga mendistribusikan sekitar 3000 bibit cengkeh pada 2011 untuk mendukung usaha ini. Penggunaan lahan terkini di Bonto Karaeng masih didominasi oleh jagung (lebih dari setengah area desa total), diikuti dengan sistem tanam campuran (cengkeh, kakao, dan kopi).

\footnotetext{
${ }^{1}$ US\$ $1,00=\operatorname{Rp} 9608$ (Desember 2012)
} 


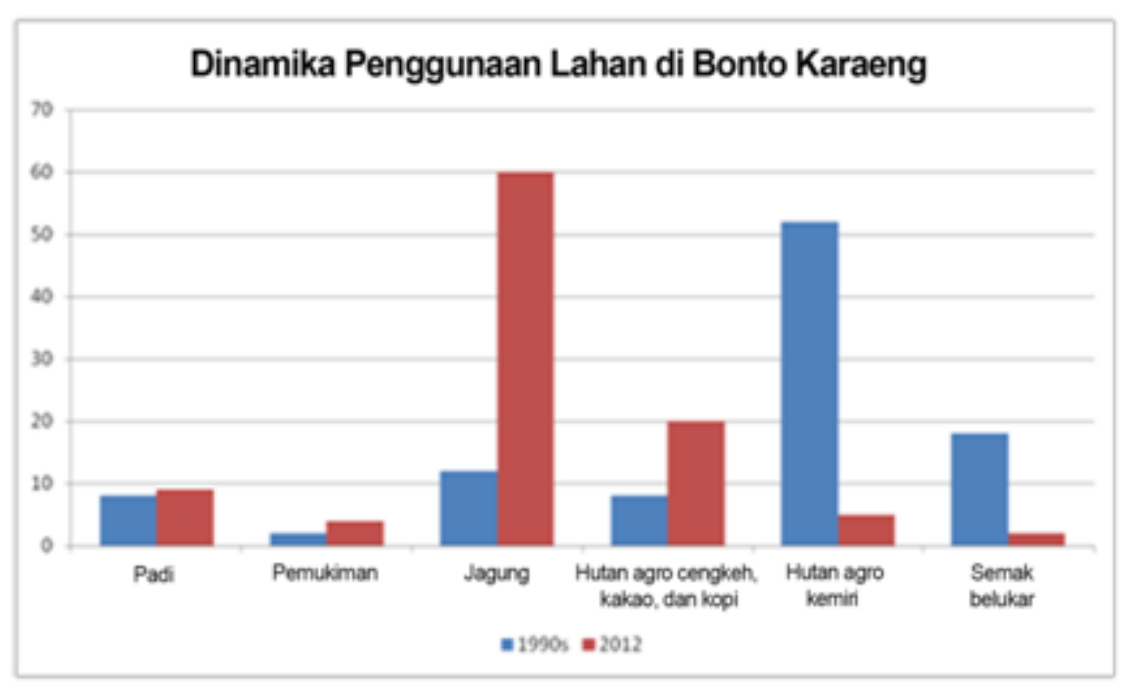

Gambar 11. Dinamika penggunaan lahan in Bonto Karaeng berdasarkan perspektif masyarakat

Gambar 11 menunjukkan ladang jadung berkembang cukup banyak selama 20 tahun terakhir. Ini terjadi bersamaan dengan penurunan agroforestri kemiri. Situasi ini sesuai dengan peningkatan pesat jagung hibrida pada periode yang sama, mirip dengan situasi di desa tetangga, Kayu Loe.

\subsubsection{Tipologi 2 (desa dengan sistem agroforestri)}

Tipologi desa ini ditemukan di Kabupaten Bantaeng dan Bulukumba. Jagung, singkong, dan padi ladang sebelumnya merupakan tanaman pokok. Dari 1990-an hingga seterusnya, tanaman perkebunan (kopi, kakao, dan cengkeh) diperkenalkan dan sistem pertanian menjadi lebih kompleks.

\section{Sistem Agroforestri di Kabupaten Bantaeng}

\section{Pattaneteang}

Pattaneteang didirikan oleh pendatang Bugis dari Wajo pada 1930-an. Tanaman pokok pada saat itu adalah kopi, jagung, ubi jalar, dan padi. Pada 1945, para petani mengairi sawah mereka (sistem irigasi merupakan warisan pemerintah kolonial Belanda) dan menanam kopi bugis yang berasal dari Wajo. Hingga 1960-an, banyak jenis kopi yang dibudidayakan di Pattaneteang seperti bugis, arabica, robusta, kate, dan husda. 


\section{Pattaneteang 2012}

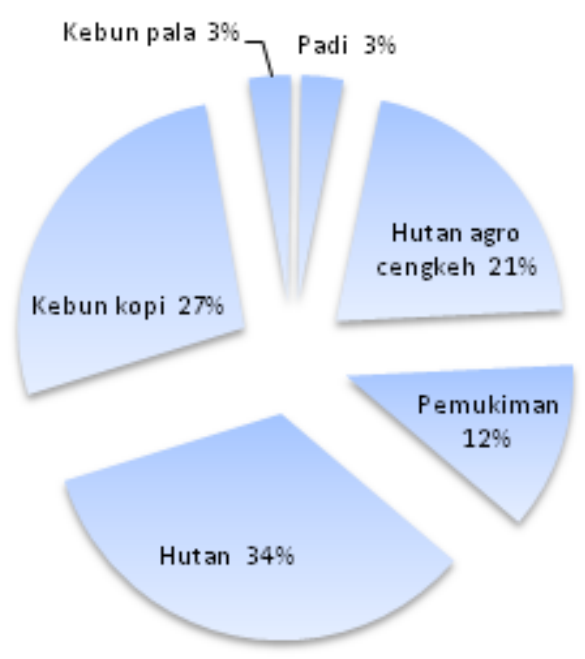

Gambar 12. Penggunaan lahan terkini di Desa Pattaneteang berdasarkan perspektif masyarakat

Dimulai pada awal 1970-an hingga 1980-an, banyak petani menanam cengkeh menggunakan bibit dari Pulau Ambon. Pada 2000-an, hutan desa dirambah untuk budi daya kopi (sekitar 150 ha) sekalipun ini tidak memengaruhi keseluruhan area hingga sekarang. Pada 2011, kakao rusak parah akibat penyakit busuk buah kakao (Phytophthora palmivora), sementara cengkeh juga rusak oleh hama penggerek batang. Sekarang luasan agroforestri kopi dan cengkeh tetap berada di posisi setelah hutan yang merupakan bentuk terbesar penggunaan lahan di Pattaneteang (Gambar 12).

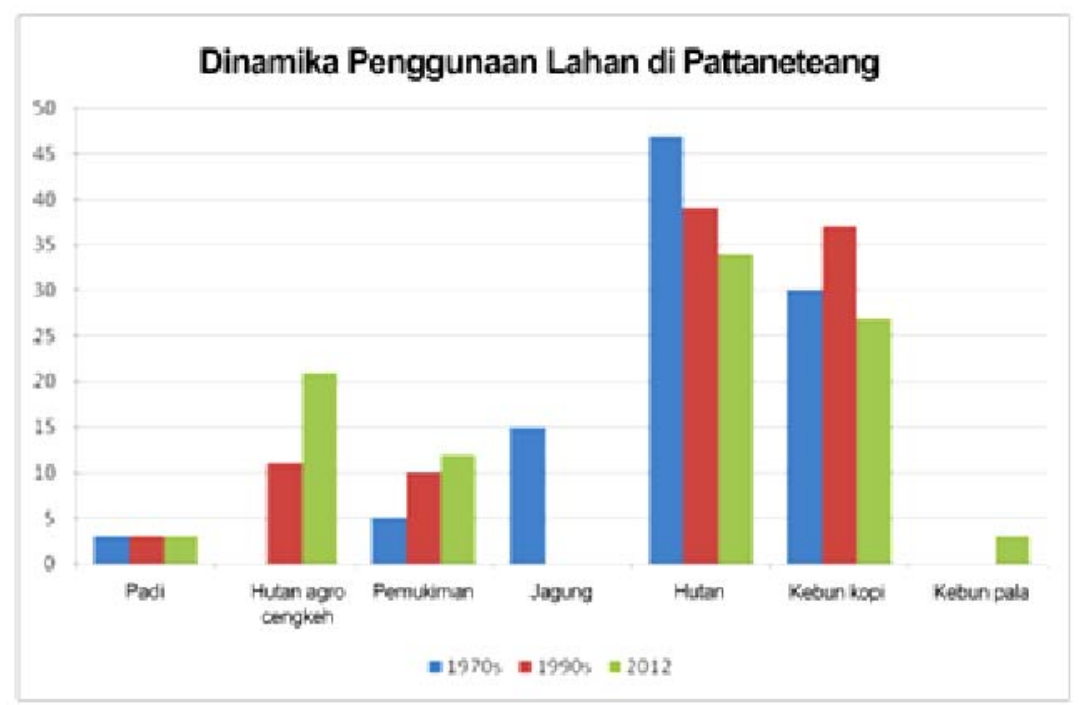

Gambar 13. Dinamika penggunaan lahan di Pattaneteang berdasarkan perspektif masyarakat

Gambar 13 menunjukkan peningkatan dalam agroforestri cengkeh selama 40 tahun terakhir dan penurunan pada area tutupan hutan. Lahan padi tidak berubah karena lahan tersebut berada di lembah yang tidak pernah dikonversi untuk penggunaan lahan lain. Ladang jagung pada akhirnya menghilang pada 2012, membuktikan adanya peningkatan pesat agroforestri cengkeh. 


\section{Campaga}

Campaga didirikan pada 1930-an oleh penduduk Makassar. Pada periode awal ini, para penduduk bertahan hidup dengan jagung, kopi (kopi bugis), buah, dan padi ladang. Pada 1965, para petani mulai menanam kopi robusta dan 20 tahun kemudian mereka memulai budi daya kopi arabica.

\section{Campaga 2012}

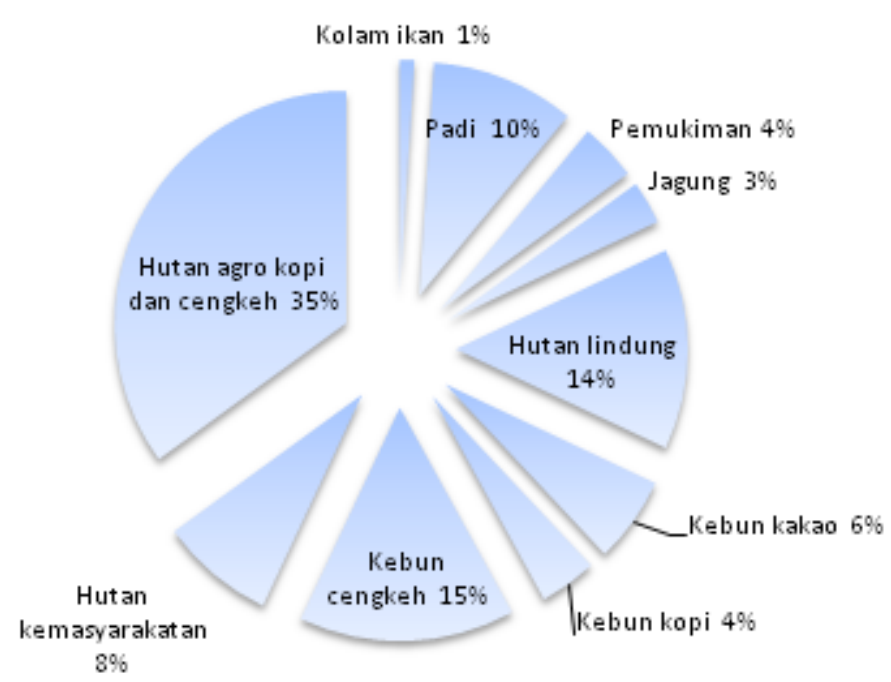

Gambar 14. Penggunaan lahan terkini di Desa Campaga berdasarkan perspektif masyarakat

Dari 1970-an hingga 2000 dan seterusnya, cengkeh dan kakao diperkenalkan kepada para petani; pemerintah menyumbangkan 30 bibit kakao kepada tiap rumah tangga. Dukungan pemerintah untuk budi daya kopi arabica tersedia melalui Proyek Rehabilitasi dan Perluasan Tanaman Ekspor (PRPTE) pada 1985 melalui skema kredit; dukungan ini dilakukan kembali untuk durian Aceh dan bibit durian lokal. Pada 2010, program Gernas memberikan bantuan untuk pencangkokan kakao oleh petani. Pada 2002, tanaman kakao terkena dampak serius hama dan penyakit dan menurunkan hasil produksi secara signifikan. Sekarang ini, sistem penggunaan lahan di Campaga didominasi oleh agroforestri kopi dan cengkeh, diikuti oleh kebun cengkeh dan hutan lindung (Gambar 15).

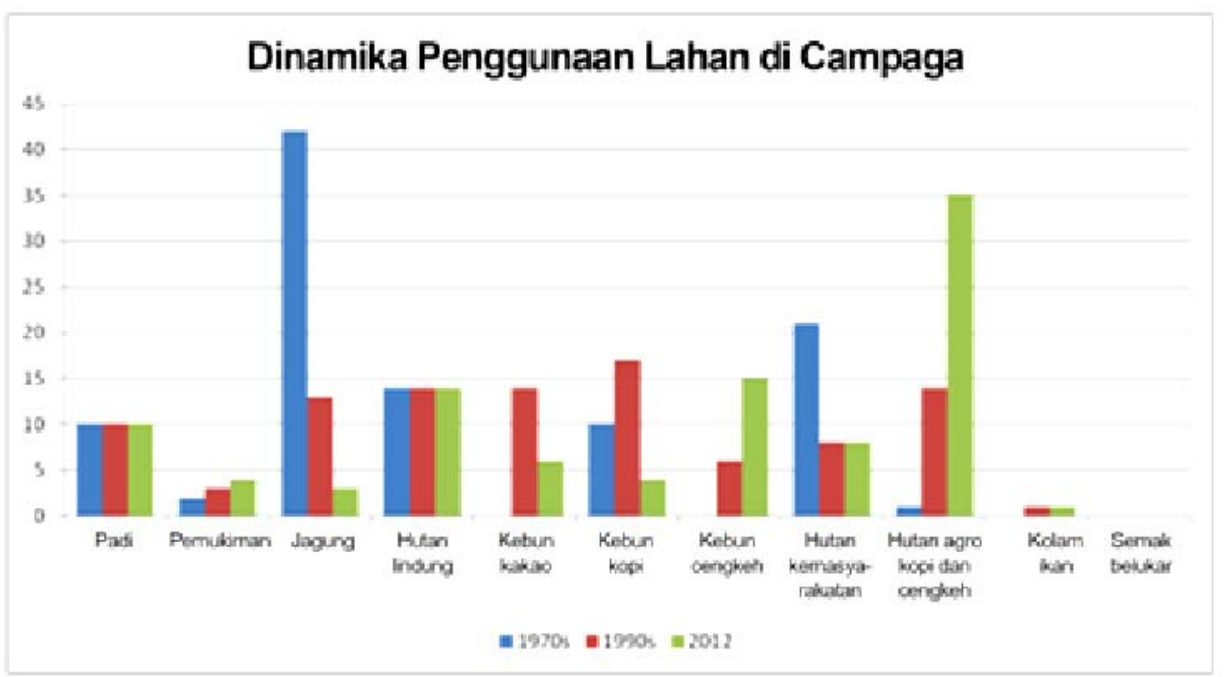

Gambar 15. Dinamika penggunaan lahan di Campaga berdasarkan perspektif masyarakat 
Gambar 15 menunjukkan area agroforestri kopi dan cengkeh meningkat dengan pesat sepanjang 40 tahun terakhir; sebaliknya, ladang jagung menurun. Area padi relatif tetap dan tidak berubah karena area ini berlokasi di lembah (seperti di Pattaneteang). Kondisi-kondisi tersebut menggambarkan peningkatan signifikan pada agroforestri kopi dan cengkeh, dan penurunan area ladang jagung.

\section{Sistem Agroforestri di Kabupaten Bulukumba}

\section{Borongrappoa}

Menurut para penduduk desa, Borongrappoa didirikan pada awal 1900-an oleh pendatang Bugis dan Makassar dari Sinjai dan Gowa yang bergantung pada jagung dan padi ladang. Pada 1945, para petani menanam kopi robusta, jagung, pisang, dan ubi jalar. Pada 1950-an, mereka mendirikan sawah tadah hujan untuk panen sekali setahun. Cengkeh pertama kali ditanam pada awal 1971, diikuti dengan kakao dan kopi arabica pada 1986. Pada 1971, para petani mendapatkan bibit cengkeh dari PT. Sulawesi dan juga Dinas Perkebunan. PT. Sulawesi awalnya mengelola sekitar 480 ha kebun cengkeh, tetapi operasi perusahaan ini bertahan hanya selama setahun karena konflik penguasaan lahan dengan masyarakat setempat.

\section{Borongrappoa, 2012}

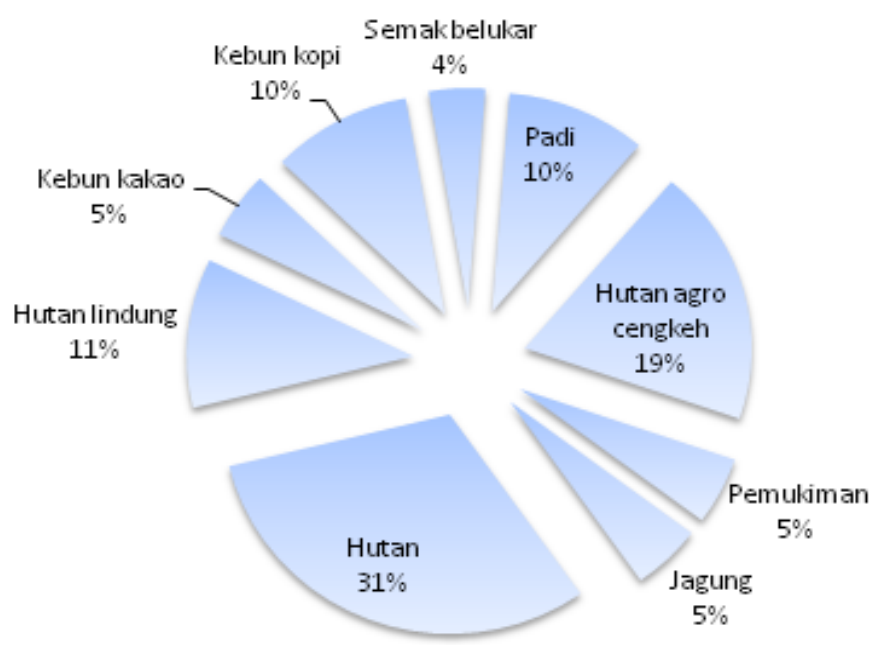

Gambar 16. Penggunaan lahan terkini di Desa Borongrappoa berdasarkan perspektif masyarakat

Pada 1987 pemerintah menyumbangkan bibit kakao. Sayangnya, pada 2006 kakao diserang penyakit busuk buah kakao dan hama penggerek batang, yang memaksa para petani untuk menebang pohon kakao mereka dan menggantinya dengan cengkeh dan kopi arabica. Penggunaan lahan terkini di Borongrappoa ditandai dengan tutupan hutan, agroforestri cengkeh, juga hutan lindung yang terjaga (Gambar 16). 


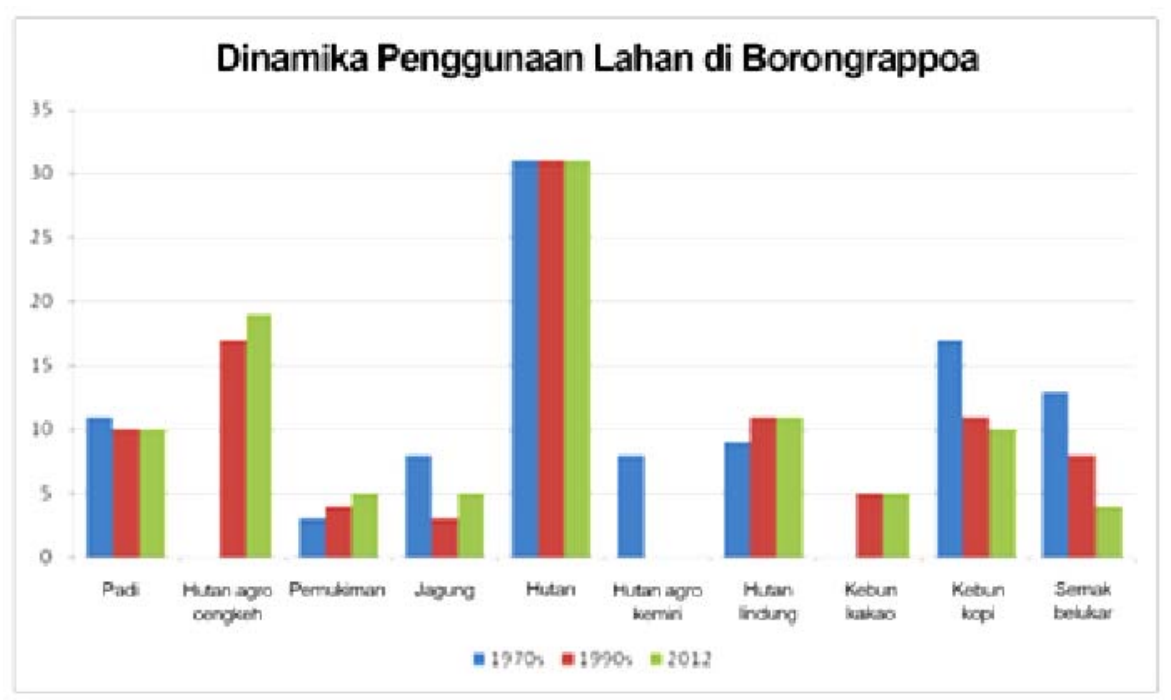

Gambar 17. Dinamika penggunaan lahan di Borongrappoa berdasarkan perspektif masyarakat

Gambar 17 menunjukkan perluasan agroforestri cengkeh selama 40 tahun terakhir, penurunan luas kebun kopi, dan hilangnya agroforestri kemiri. Area tutupan hutan tetap tidak berubah selama periode ini.

\section{Balangpesoang}

Balangpesoang didirikan pada 1920-an oleh suku Bugis pendatang yang nafkah hidupnya dipenuhi dari jagung, singkong, kopi bugis, dan padi ladang. Pada 1970-an ada lebih banyak pendatang berdatangan dari Sinjai, Bulukumba, dan Ujung Pandang untuk membeli tanah dan menanam cengkeh. Pada akhir 1970-an, banyak masyarakat desa asli yang mengikuti tren mendirikan kebun cengkeh. Awal 1980-an adalah awal penanaman lada dan kakao.

\section{Balangpesoang 2012}

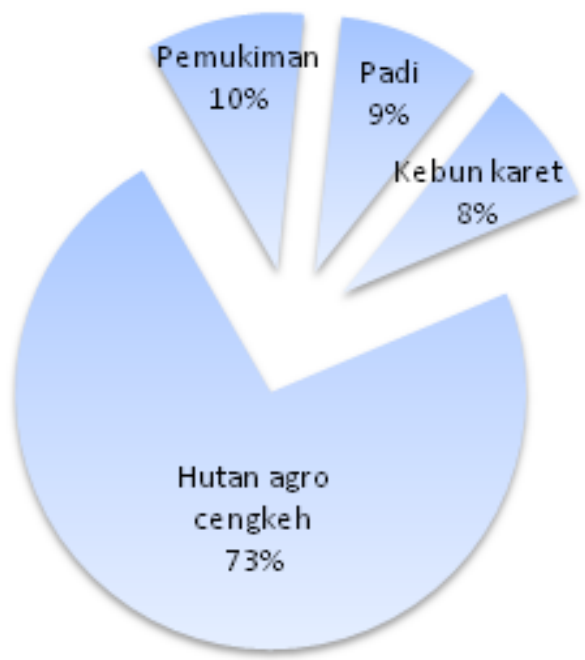

Gambar 18. Penggunaan lahan terkini di Desa Balangpesoang berdasarkan perspektif masyarakat

Pada 1998, sekitar 5 ha kebun karet dikembangkan oleh penduduk desa pendatang yang menjual karet kepada PT. Sulawesi berdasarkan kontrak. Baru-baru ini, banyak petani menanam jenis 
pohon buah seperti rambutan, durian otong, durian cipaku, dan manggis. Penggunaan lahan desa terkini sekarang didominasi oleh agroforestri cengkeh dengan kopi, kakao, pohon buah dan kayu (Gambar 19).

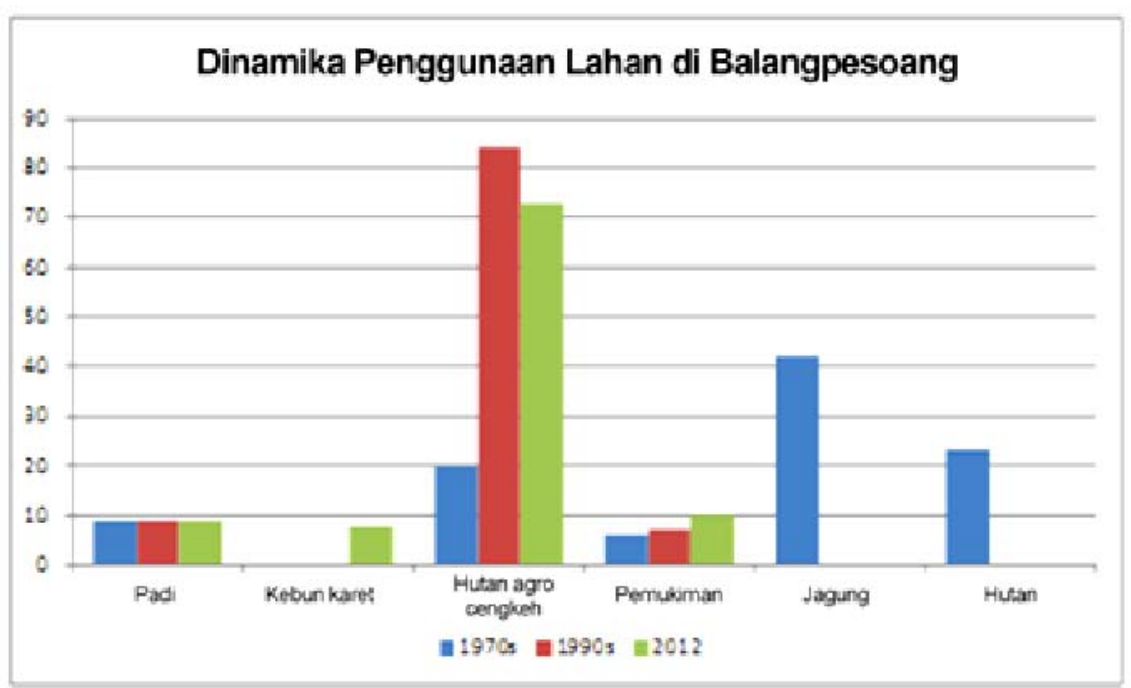

Gambar 19. Dinamika penggunaan lahan di Balangpesoang berdasarkan perspektif masyarakat

Gambar 19 menunjukkan peningkatan signifikan pada budi daya cengkeh selama 40 tahun terakhir dan hilangnya area ladang jagung dan hutan di desa setelah 1970-an. Budi daya karet dimulai baru pada waktu belakangan. Data membuktikan peningkatan cengkeh yang pesat menggantikan budi daya jagung dan area tutupan hutan.

\subsubsection{Tipologi 3 (desa dengan sistem berbasis kayu)}

Para penduduk desa di Tipologi 3 mengenal sistem kayu yang dapat dipasarkan (komersial) dengan baik, menggunakan jenis kayu seperti jati, mahoni, suren, jati putih, dan sengon. Namun, kegiatan penggunaan lahan yang utama meliputi praktik agroforestri dengan kelapa, kopi, cengkeh, jagung, dan spesies pohon.

\section{Tugondeng}

Tugondeng didirikan pada masa kolonial Belanda oleh suku Bugis pendatang dari Bone yang menanam jagung, padi ladang, dan ubi jalar. Pada 1945, desa ini masih dikenal sebagai kesultanan. Secara demografis, para suku Bugis pendatang ini sekarang digantikan oleh suku Konjo pendatang yang mendominasi Tugondeng.

Pada 1980-an, pemerintah memberikan dukungan dalam bentuk kelapa hibrida dan para penduduk desa mulai menanam kakao pada masa ini, menanam tumpang sari kelapa dan kakao di kebun yang sama. Pada 1995, dilaksanakan program dukungan penyuluhan ekstensif selama 3 bulan mengenai cara pembuatan gula kelapa. Program ini memberikan peralatan menyadap, kompor, dan panci yang digunakan dalam proses pembuatan gula kelapa. 


\section{Tugodeng 2012}

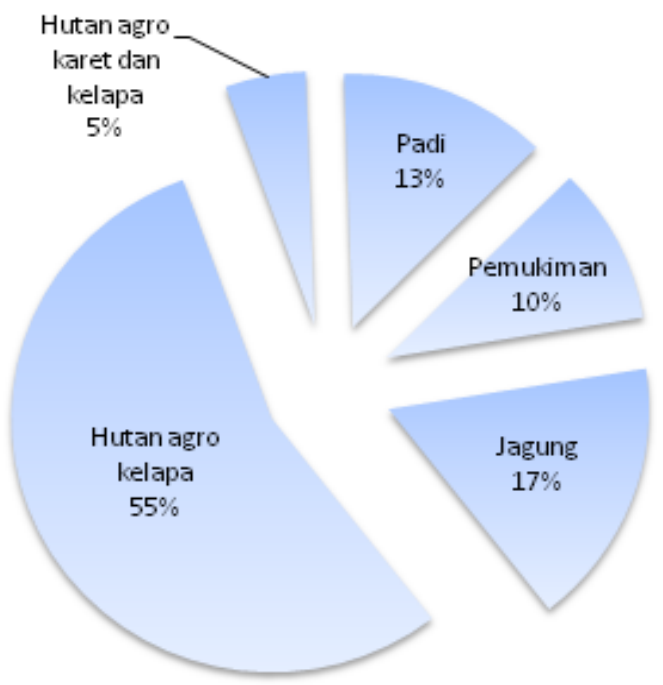

Gambar 20. Penggunaan lahan terkini di Desa Tugondeng berdasarkan perspektif masyarakat

Agroforestri kelapa sekarang menjadi praktik penggunaan lahan utama di desa ini, ditambah dengan budi daya jagung dan padi. Kakao, padi, dan pohon kayu diintegrasikan ke dalam agroforestri kelapa. Kebun pohon kayu (menggunakan jenis pohon seperti jati, mahoni, suren, jati putih, dan sengon) juga dipertahankan (Gambar 21).

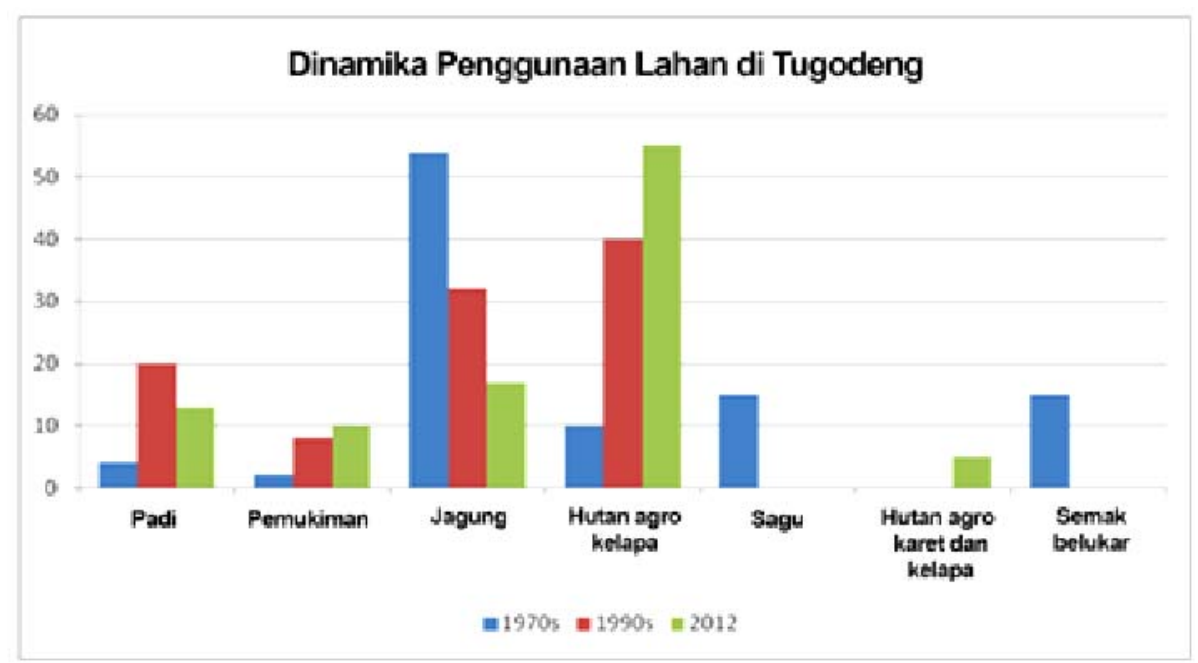

Gambar 21. Dinamika penggunaan lahan di Tugondeng berdasarkan perspektif masyarakat

Gambar 21 menunjukkan peningkatan yang relatif signifikan pada agroforestri kelapa selama 40 tahun terakhir dan penurunan budi daya jagung. Lahan sagu dan semak belukar menghilang pada 2012.

\section{Tana Towa}

Tana Towa berarti desa tertua. Desa ini terkenal sebagai desa tradisional yang memiliki ikatan budaya yang sangat kuat di Sulawesi Selatan. Desa ini awalnya didirkan oleh suku Konjo yang bertahan hidup dengan menanam padi ladang, jagung, kopi, kelapa, dan pisang pada saat itu. 
Keterlibatan adat atau masyarakat dalam pengelolaan hutan, di mana hutan memainkan peran penting dalam mata pencaharian di pedesaan, kemungkinan besar memicu perubahan substansial dalam cara pengelolaan hutan, memastikan pengamanan dan/atau diversifikasi beragam

keuntungan hutan. Komponen keamanan sosial pengelolaan hutan kemasyarakatan dapat menjadi signifikan (Arnold 2001). Pohon dan hutan memberikan serangkaian keuntungan dalam bentuk barang dan jasa yang muncul dari penggunaan langsung dan tidak langsung (Arnold dan Bird 1999).

\section{Tana Towa 2012}

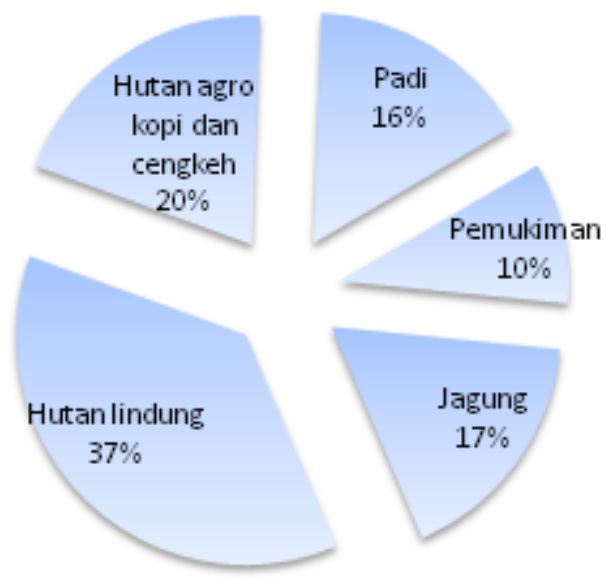

Gambar 22. Penggunaan lahan terkini di Tana Towa berdasarkan perspektif masyarakat

Pada 1990-an masyarakat tertarik untuk menanam cengkeh sebagai opsi mata pencaharian lewat intervensi pemerintah. Dari 1991 hingga 1998, lada, kakao, dan cengkeh menjadi tanaman utama desa.

Sekarang ini, penggunaan lahan utama adalah hutan lindung yang meliputi 1/3 dari area desa total (Gambar 23). Pengawasan tradisi dan adat yang ketat melindungi hutan desa dari deforestasi. Agroforestri kopi dan cengkeh merupakan praktik penggunaan lahan sekunder.

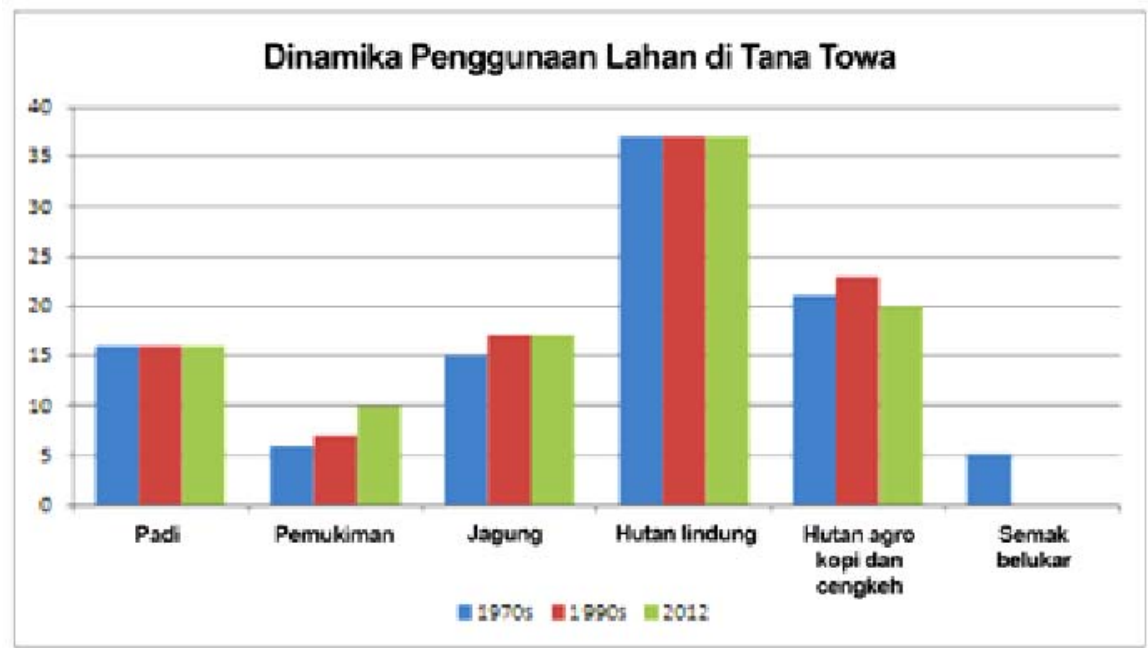

Gambar 23. Dinamika penggunaan lahan di Tana Towa berdasarkan perspektif masyarakat 
Gambar 23 menunjukkan penggunaan lahan mengalami sangat sedikit perubahan selama 40 tahun terakhir dikarenakan hukum adat yang kuat yang juga melindungi hutan dari perambahan. Ada sedikit peningkatan dalam jumlah pemukiman dan area yang ditanami jagung.

\subsection{Perspektif rumah tangga mengenai karakteristik lahan}

\subsubsection{Karakteristik lahan di Sulawesi Selatan}

\section{Aksesibilitas ke lahan}

\section{Lokasi lahan}

Sebagian besar budi daya tanaman di semua area berlokasi di lahan pribadi di dalam desa dan sisanya di luar desa, akan tetapi persentasenya kecil. Hutan lindung hanya terdapat pada area lahan terdegradasi(Gambar 24).

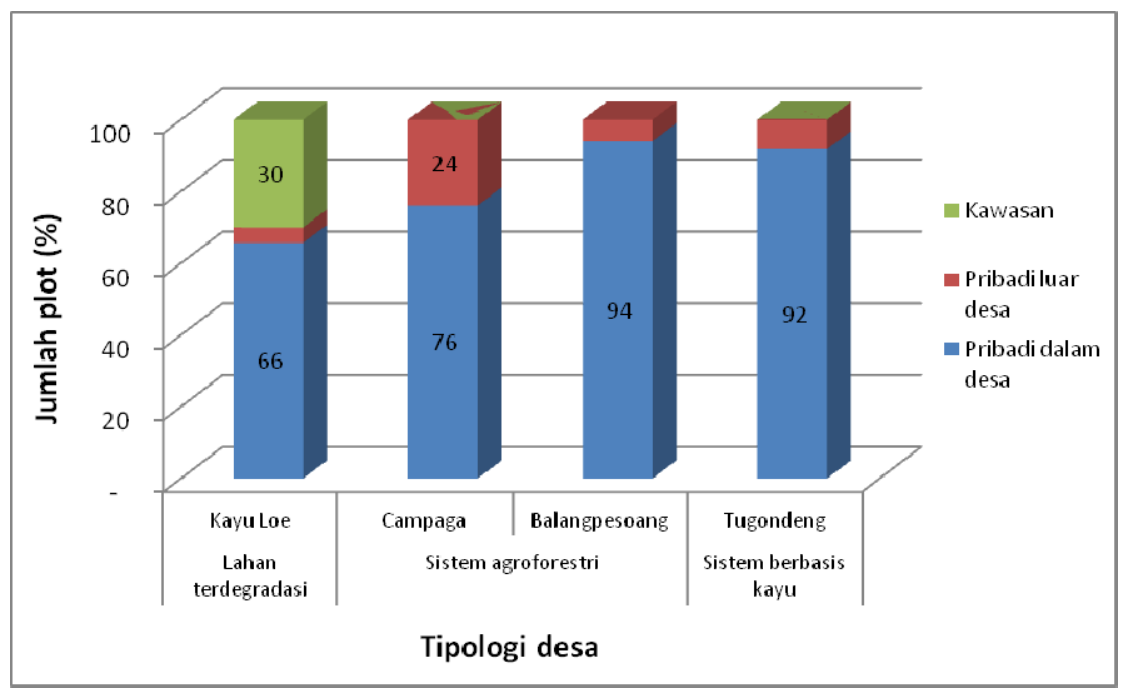

Gambar 24. Lokasi lahan di Sulawesi Selatan

Jarak dari rumah ke lahan petani dengan berjalan kaki

Rata-rata waktu yang dibutuhkan untuk berjalan kaki dari rumah ke lokasi lahan relatif sama pada ketiga tipologi, yaitu tidak lebih dari satu jam atau kurang lebih 30 menit. 


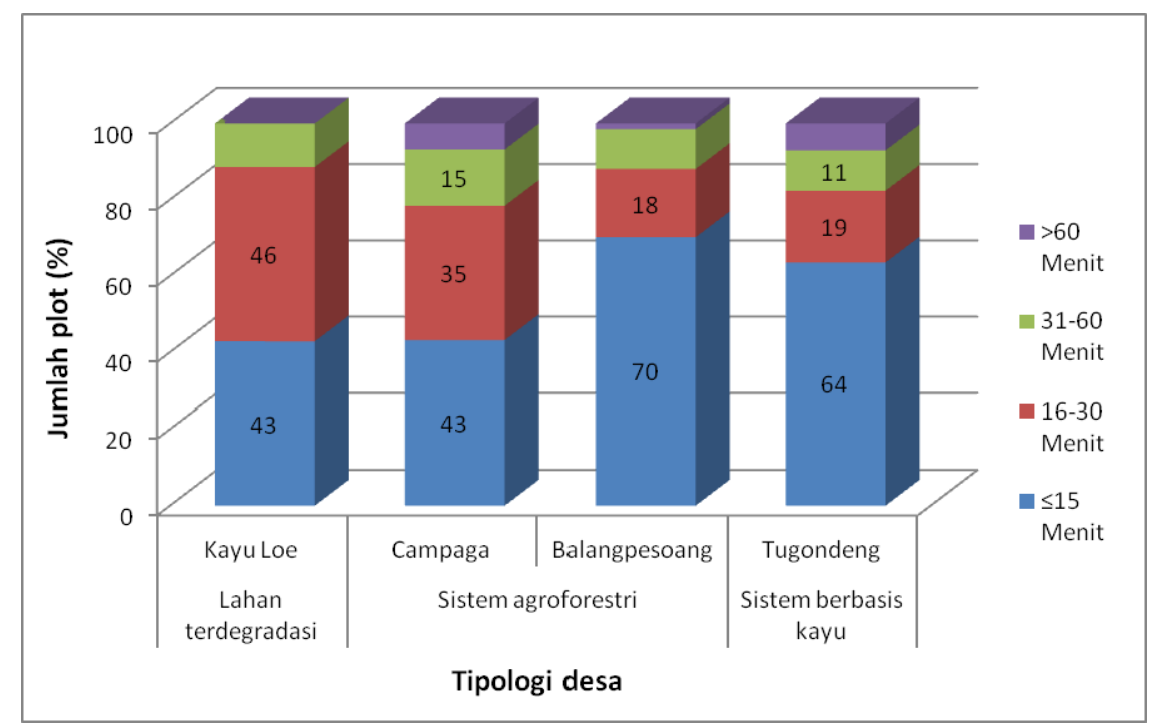

Gambar 25. Waktu berjalan kaki dari rumah menuju ke lahan di Sulawesi Selatan

\section{Permukaan lahan}

Permukaan lahan dalam ketiga tipologi didominasi oleh miring, sisanya permukaan lahan berbentuk datar (Gambar 26).

\section{Kemiringan tanah}

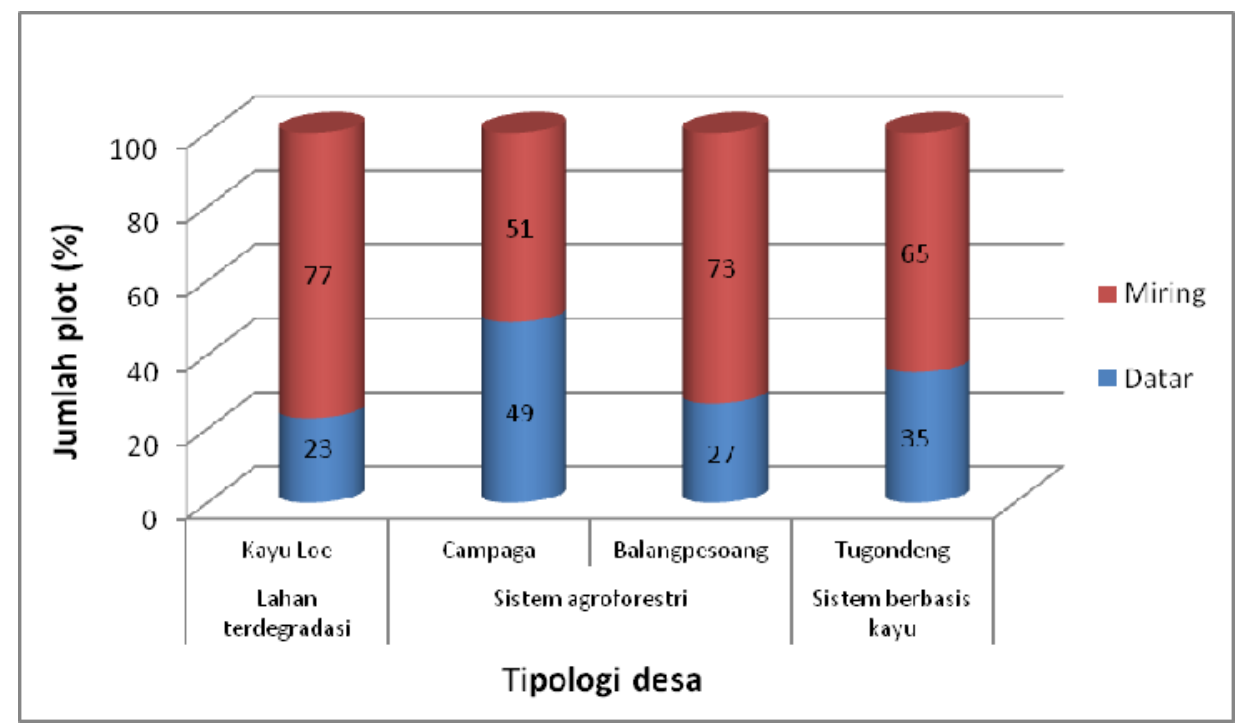

Gambar 26. Permukaan lahan di Sulawesi Selatan

\section{Pengelolaan lahan saat ini}

Status pengelolaan lahan di ketiga tipologi relatif sama, sebagian besar dikuasai dan digarap sendiri (Gambar 27). Adapun cara mendapatkan lahan sebagian besar dengan cara warisan atau pembelian (Gambar 28) 


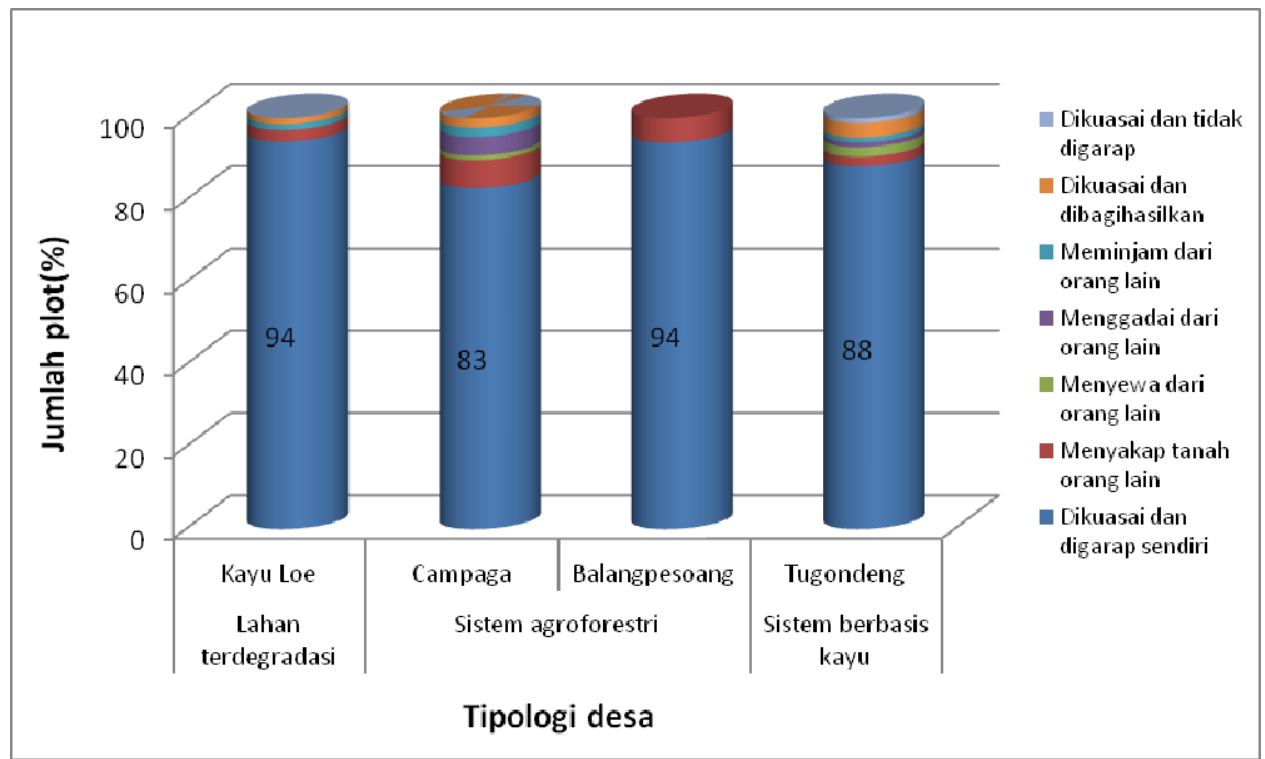

Gambar 27. Status pengelolaan lahan di Sulawesi Selatan

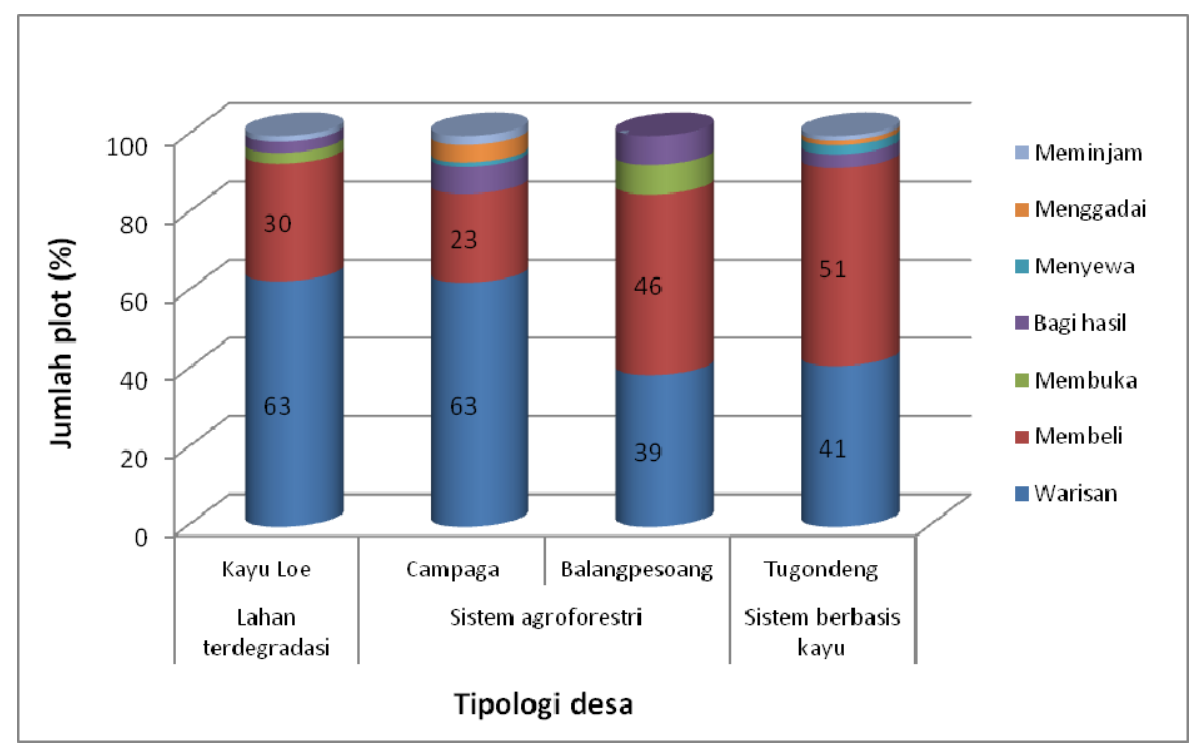

Gambar 28. Cara menguasai lahan di Sulawesi Selatan

\section{Sumber lahan}

Kebanyakan lahan di Tipologi 1 berasal dari orangtua suami, pada Tipologi 2 dari orangtua suami dan orang lain, sementara di Tipologi 3 lahan berasal dari orang lain. 


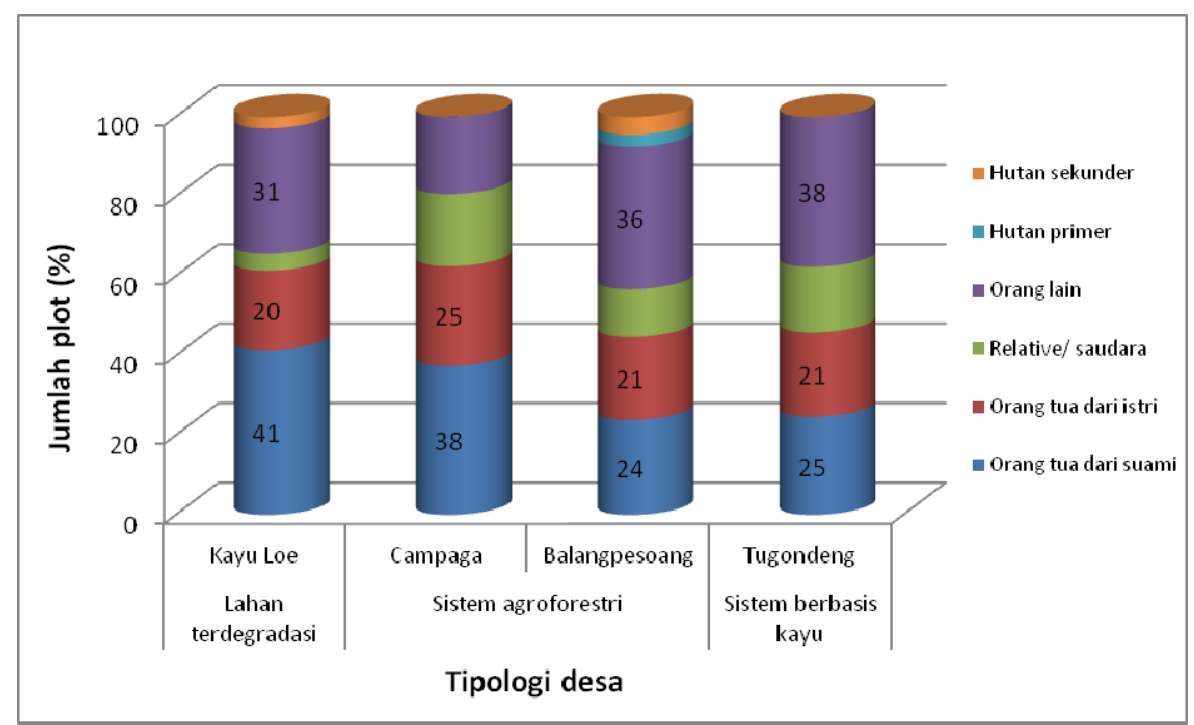

Gambar 29. Sumber lahan di Sulawesi Selatan

Gambar 29 menunjukkan bahwa pada Tipologi 1, sebesar 41\% lahan berasal dari orangtua suami, selanjutnya dari orang lain (31\%), dan dari orangtua istri (20\%). Pada Tipologi 2, sebesar 24-38\% lahan berasal dari orangtua suami, selanjutnya dari orangtua istri (21-55\%), orang lain (19-36\%), dan sumber lain (18-19\%). Sebagian besar kepemilikan lahan pada Tipologi 3 berasal dari orang lain (38\%), selanjutnya dari orangtua suami (25\%), orangtua istri (21\%), dan saudara (16\%)

\section{Tahun penguasaan lahan}

Distribusi kepemilikan lahan berdasarkan tahun kepemilikan lahan berbeda pada ketiga tipologi. Sebagian besar kepemilikan lahan pada Tipologi 1 dan 3 diperoleh setelah 2000, sementara pada Tipologi 2, lahan diperoleh pada 1980-1989 dan 1990-1999.

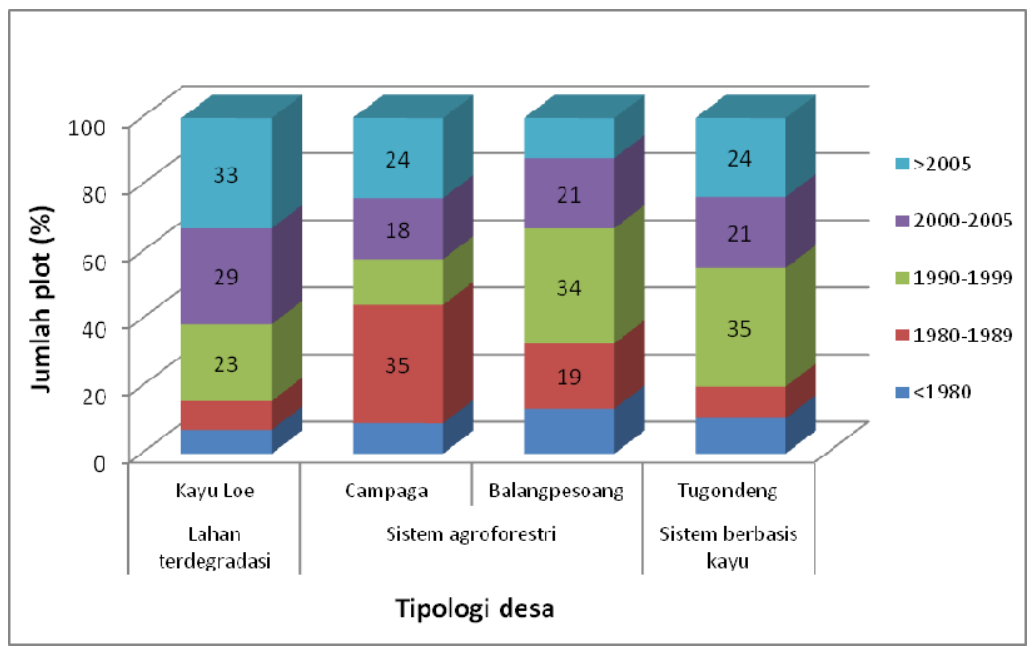

Gambar 30. Tahun penguasaan lahan di Sulawesi Selatan

Gambar 30 menunjukkan sebagian besar lahan pada Tipologi 1 didapatkan pada tahun-tahun setelah 2000 (62\%) dan 23\% pada 1990-1999. Pada Tipologi 2, 35\% lahan yang dimiliki di Desa Campaga didapatkan pada periode 1980-1989 dan 24\% setelah 2005; di Desa Balangpesoang, 34\% 
lahan yang dimiliki didapatkan pada periode 1990-1999 dan 33\% setelah 2000. Di sisi lain, sebagian besar lahan pada Tipologi 3 didapatkan setelah tahun 2000 (45\%) dan dari 1990-1999 (35\%).

\subsubsection{Status kepemilikan dan penggunaan lahan di Sulawesi Selatan}

\section{Status kepemilikan lahan}

Status kepemilikan lahan pada Tipologi 1 dan 2 hampir sama, namun pada Tipologi 3 berbeda. Sebagian besar kepemilikan lahan pada Tipologi 1 dan 2 adalah dimiliki oleh suami, sedangkan di Tipologi 3 adalah lahan bersama (suami dan istri) (Gambar 31).

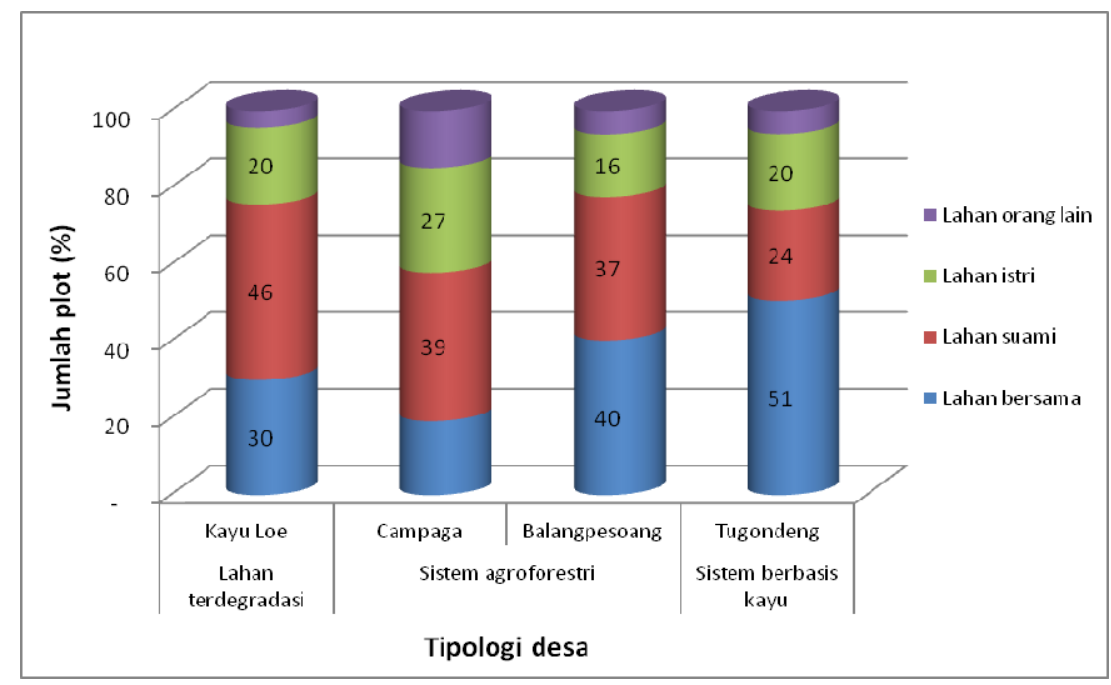

Gambar 31. Status kepemilikan lahan terkini di Sulawesi Selatan

\section{Pola penggunaan lahan sebelum saat ini}

Sebagian besar penggunaan lahan sebelum saat ini pada Tipologi 1 adalah berupa ladang jagung, sedangkan di Tipologi 2 berupa kebun campur (agroforestri), dan pada Tipologi 3 berupa agroforestri kelapa.

Gambar 32 menunjukkan bahwa penggunaan lahan sebelum saat ini pada Tipologi 1 didominasi oleh ladang jagung (77\%), diikuti dengan agroforestri kopi (13\%) dan tanaman lain (10\%). Penggunaan lahan sebelum ini pada Tipologi 2 berupa kebun campur/agroforestri (30-33\%), ladang jagung (25-27\%), agroforestri cengkeh (33\%), sawah (17\% di Balangpesoang), semak belukar (6-11\% di Campaga), dan tanaman lain (6-14\%). Pada Tipologi 3, ladang jagung (34\%), agroforestri kelapa (28\%), agroforestri kakao (11\%), kebun campur (10\%), sawah (8\%), semak belukar ( 7\%), dan kebun kayu (2\%) adalah pola penggunaan lahan sebelum ini. 


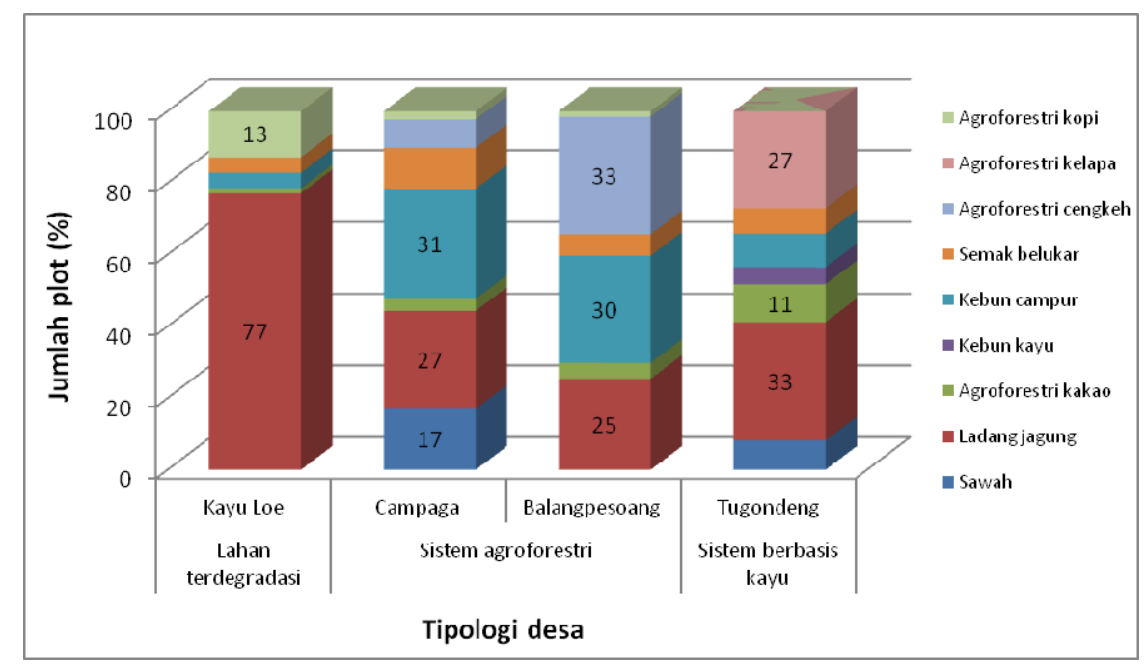

Gambar 32. Pola penggunaan lahan sebelum saat ini di Sulawesi Selatan

\section{Pola penggunaan lahan saat ini}

Sebagian besar penggunaan lahan saat ini pada Tipologi 1 adalah berupa ladang jagung, sedangkan di Tipologi 2 berupa kebun campur (agroforestri), dan pada Tipologi 3 berupa agroforestri kelapa

Pada Tipologi 1, ladang jagung (69\%) terlihat sangat mendominasi penggunaan lahan saaat ini, diikuti dengan agroforestri kopi (20\%). Pada Tipologi 2, kebun campur (60-75\%) dan agroforestri cengkeh (14-19\%) mendominasi. Pada Tipologi 3, agroforestri kelapa (38\%), kebun campur (24\%), agroforestri kakao (18\%), kebun kayu (9\%), sawah (7), dan tanaman lain (5\%) adalah pola penggunaan lahan terkini (Gambar 33).

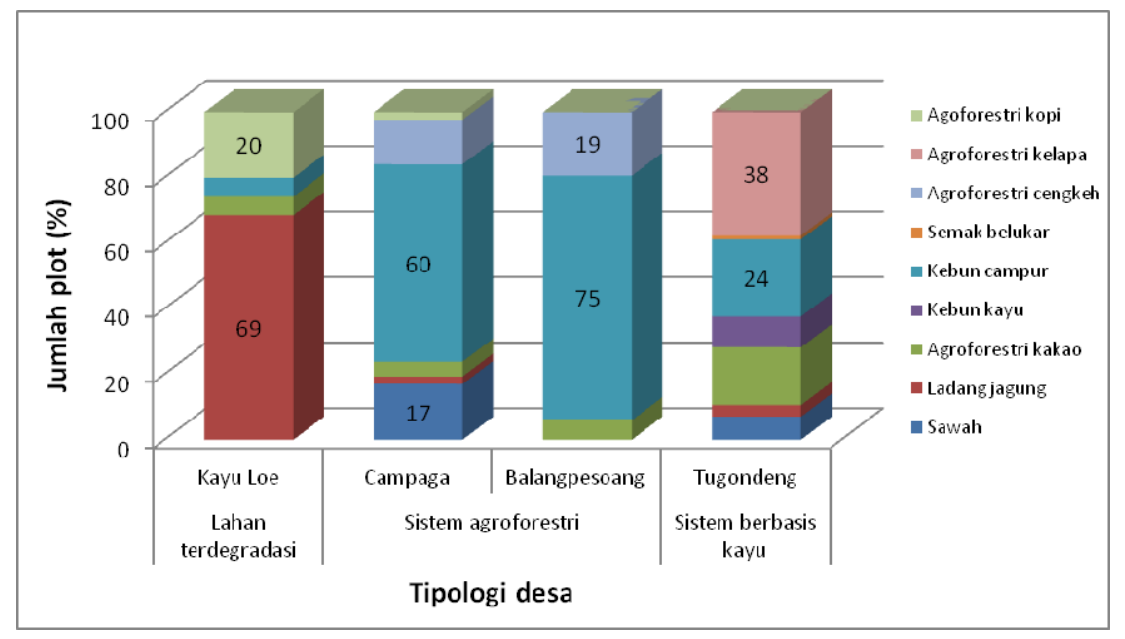

Gambar 33. Pola penggunaan lahan saat ini di Sulawesi Selatan

\section{Penggunaan lahan sebelum dan satu tahun setelah dikuasai}

Penggunaan lahan sebelum dan satu tahun setelah dikuasai dijelaskan secara detail pada Gambar 34 dan Gambar 35. 
Penggunaan lahan sebelum dikuasai berbeda pada ketiga tipologi. Pada Tipologi 1 sebagian besar penggunaan lahan sebelum dikuasai berupa ladang jagung, pada Tipologi 2 berupa semak belukar dan agroforestri cengkeh, sedangkan pada Tipologi 3 berupa semak belukar.

Penggunaan lahan satu tahun setelah dikuasai juga berbeda pada ketiga tipologi. Pada Tipologi 1 sebagian besar berupa ladang jagung, pada Tipologi 2 berupa agroforestri (kebun campur), sedangkan pada Tipologi 3 berupa ladang dan agroforestri coklat

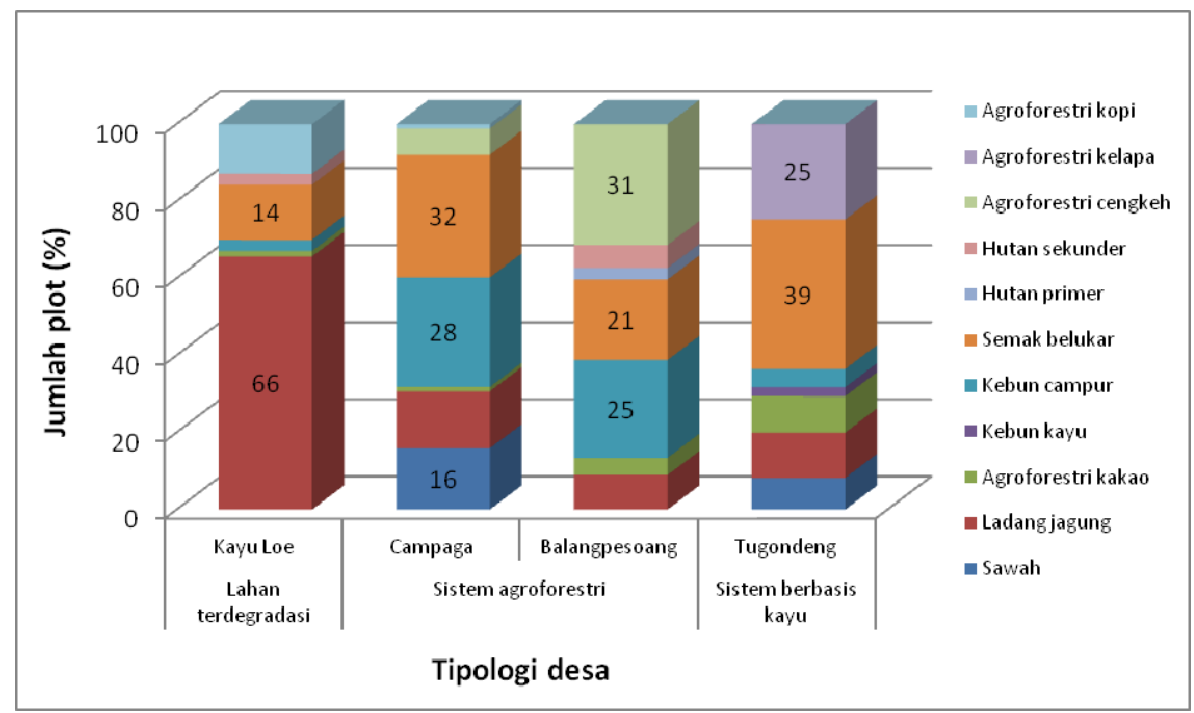

Gambar 34. Penggunaan lahan sebelum dikuasai di Sulawesi Selatan

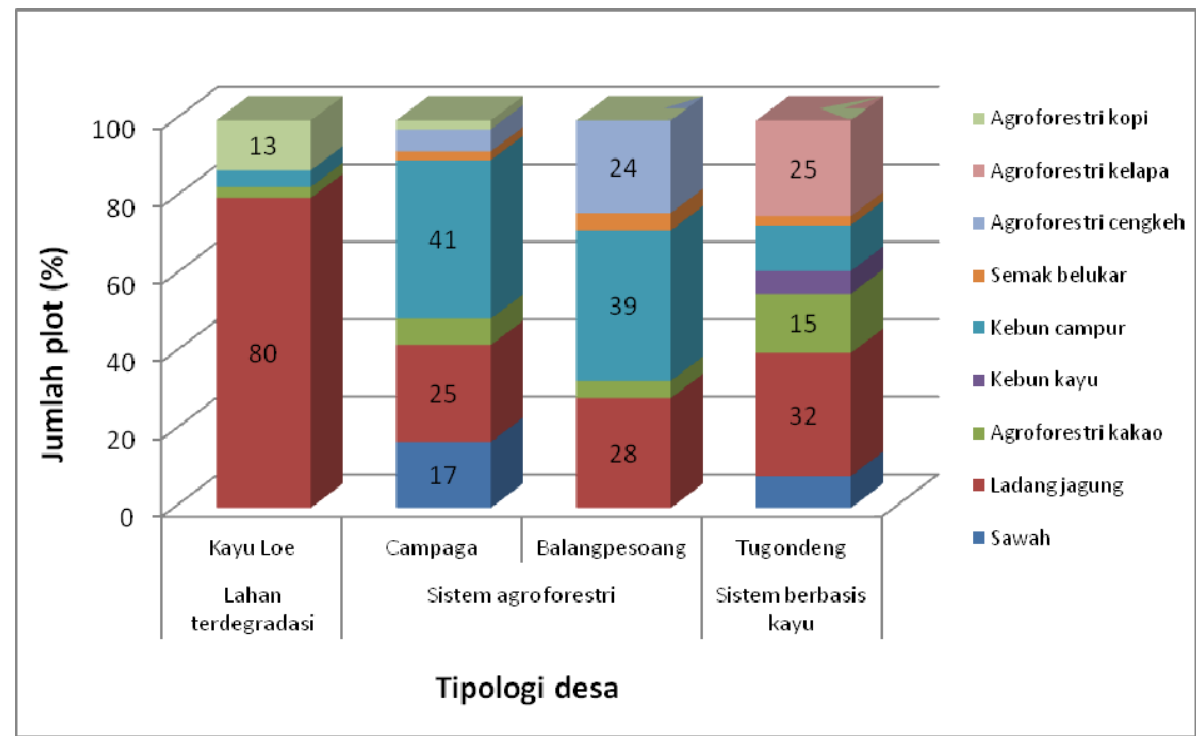

Gambar 35. Penggunaan lahan satu tahun setelah dikuasai di Sulawesi Selatan

\section{Distribusi tanaman pada penggunaan lahan saat ini}

Lima tipe jenis tanaman yang ditanam oleh para petani dalam kondisi berbeda-beda di tiap desa. Rata-rata jumlah tanaman per hektar di Sulawesi Selatan dirangkum di dalam tabel 4. Di Sulawesi Selatan pada umumnya kebun ditanami dengan tanaman tahunan, tanaman multifungsi (multipurpose trees/MPTs), seperti tanaman buah-buahan, kayu, pisang, dan penaung (gamal). Tanaman kayu terbanyak ditanam oleh petani pada Tipologi 3 dibandingkan dengan Tipologi 
lainnya. Pada tipologi 1 didominasi oleh tanaman tahunan (kakao dan kopi, 71\%). Sedangkan pada Tipologi 2 didominasi oleh tanaman tahunan dan tanaman multifungsi (MPTs), seperti tanaman buah-buahan. Persentase tanaman tahunan sedikit lebih tinggi daripada MPTs. Pada tipologi 3, distribusi tanaman terdiri atas tanaman kayu (36\%), tanaman tahunan (45\%), dan MPTs (15\%).

Tabel 4. Distribusi rata-rata jumlah tanaman per hektar di Sulawesi Selatan

\begin{tabular}{|c|c|c|c|c|c|c|c|c|c|c|c|c|}
\hline \multirow{3}{*}{ Tipologi desa } & \multirow{3}{*}{ Desa } & \multirow{3}{*}{$\mathrm{n}$} & \multicolumn{10}{|c|}{ Rata-rata jumlah tanaman per hektar } \\
\hline & & & \multicolumn{2}{|c|}{$\begin{array}{l}\text { Tanaman } \\
\text { tahunan }\end{array}$} & \multicolumn{2}{|c|}{$\begin{array}{l}\text { Tanaman } \\
\text { multifungsi }\end{array}$} & \multicolumn{2}{|c|}{ Kayu } & \multicolumn{2}{|c|}{ Pisang } & \multicolumn{2}{|c|}{$\begin{array}{l}\text { Tanaman } \\
\text { penaung }\end{array}$} \\
\hline & & & $\mathrm{n}$ & $\%$ & $\mathrm{n}$ & $\%$ & $\mathrm{n}$ & $\%$ & $\mathrm{n}$ & $\%$ & $\mathrm{n}$ & $\%$ \\
\hline $\begin{array}{l}\text { Lahan } \\
\text { terdegradasi }\end{array}$ & Kayu Loe & 557 & 397 & 71 & 62 & 11 & 56 & 10 & 12 & 2 & 30 & 5 \\
\hline \multirow{2}{*}{$\begin{array}{l}\text { Sistem } \\
\text { agroforestri }\end{array}$} & Campaga & 781 & 475 & 61 & 237 & 30 & 40 & 5 & 24 & 3 & 5 & 1 \\
\hline & Balangpesoang & 534 & 236 & 44 & 236 & 44 & 46 & 9 & 7 & 1 & 9 & 2 \\
\hline $\begin{array}{l}\text { Sistem } \\
\text { berbasis kayu }\end{array}$ & Tugondeng & 742 & 336 & 45 & 112 & 15 & 264 & 36 & 30 & 4 & 0 & 0 \\
\hline
\end{tabular}

\section{Opsi mata pencaharian masyarakat}

\subsection{Tipologi 1 (desa berlahan terdegradasi dengan tanaman tahunan sebagai sistem pertanian utama)}

Jagung, kentang, bawang merah, dan padi adalah tanaman utama pada tipologi ini. Belum ada sistem pertanian berbasis pohon yang dominan sejak penurunan produksi kemiri.

Jagung dan tanaman lain

Jagung adalah tanaman yang signifikan untuk beberapa desa di Kabupaten Bantaeng, terutama di bagian barat. Survei di 2 desa, Kayu Loe dan Bonto Karaeng, menunjukkan bahwa budi daya jagung adalah mata pencaharian utama (Gambar 36).

Pada awalnya, para petani menanam varietas jagung lokal yang memiliki produktivitas rendah. Mereka menanam jagung sebagai tanaman yang menafkahi mereka. Dengan kedatangan jagung hibrida, diperkenalkan antara 1985 dan 1990, produksi jagung meningkat cukup tinggi. Banyak petani di dua desa tersebut tertarik menanam jagung dan tanaman lain, seperti kentang dan bawang merah.

Tingginya permintaan untuk budi daya jagung mendorong terjadinya konversi hutan atau lahan semak menjadi ladang jagung. Di beberapa tempat, banyak petani yang tidak memikirkan pelestarian tanah selama budi daya jagung, mengarah ke penurunan kesuburan tanah yang drastis. Hal ini terbukti dari luasnya lahan sangat kritis sekarang ini, dinamakan Bonto Rampan.

\section{Jaqung}

Benih jagung yang digunakan biasanya varietas dengan kualitas yang ditingkatkan, seperti Bisi-2, NK-22, dan NK-33. Masyarakat juga menggunakan jagung kuning yang didapatkan dari 
pemerintah atau benih yang mereka kembangkan sendiri. Penanaman ditandai dengan pengaturan jarak 20 x $80 \mathrm{~cm}$ atau $20 \times 75 \mathrm{~cm}$.

Para petani menggunakan pupuk ZA dan urea yang disebar dua sekali dalam setahun. Penggunaan pertama biasanya ketika jagung berumur 25 hari dan penggunaan kedua ketika jagung berumur 40 hari. Panen dimulai pada bulan keempat hingga kelima dengan produksi rata-rata 3-4 ton per hektar (jagung yang dikeringkan). Masyarakat biasanya menjual jagung hasil panen di Bantaeng pada harga Rp 1300 per kilogram (kering).

Saat ini kendala utama dalam pertanian jagung untuk masyarakat ini adalah:

- Tingginya harga benih jagung

- Pupuk dan obat-obatan kimia (pestisida) yang mahal

- Harga eceran jagung yang sangat fluktuatif

\section{Kentang}

Para petani menggunakan benih kentang seperti P-2, Amola, B-1 dan B-2 dengan pengaturan jarak 50 x $50 \mathrm{~cm}$. Ladang dirawat sekali dalam setahun dengan penyiangan dan penggunaan pupuk urea, pupuk organik atau pupuk kandang.

Dalam satu musim tanam, kentang berusia 3-4 bulan dapat menghasilkan 400 kaleng kentang per hektar ( 1 kaleng = $15 \mathrm{~kg}$ ) atau sekitar 6 ton per hektar. Kentang biasanya dipasarkan di dalam dan luar desa pada harga Rp 60000 per kaleng atau sekitar Rp 4000 per kilogram. Kendala utama yang dihadapi oleh para petani adalah benih kentang yang mahal dan sulit didapatkan, juga musim hujan yang tidak tentu yang berpengaruh pada panen.

\section{Bawang merah}

Pada umumnya para petani menggunakan benih Palipi, Flores, dan Bima yang tersedia di toko pertanian. Bawang merah diatur jaraknya pada 20 x $20 \mathrm{~cm}$. Pupuk urea dan pupuk kandang digunakan sekali dalam setahun dan pupuk cair digunakan dua kali seminggu pada tanaman bawang merah.

Bawang merah dapat dipanen pada usia 70 hari dengan produksi sekitar 4 ton per hektar. Bawang merah dijual ke pasar di dalam dan luar desa dengan harga Rp 2500 per kilogram.

\section{Bonto Karaeng 2012}

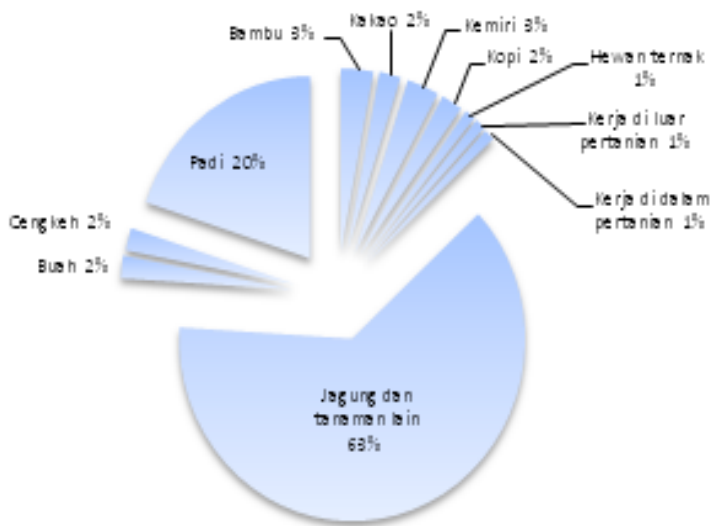

Kayu Loe 2012

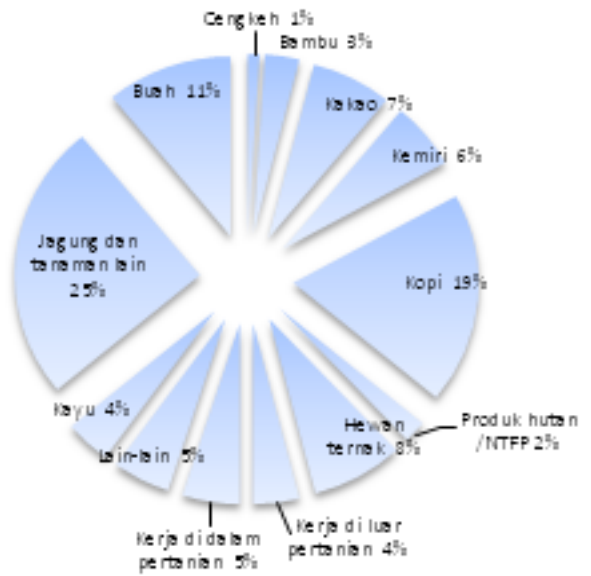

Gambar 36. Opsi mata pencaharian terkini di Kayu Loe dan Bonto Karaeng berdasarkan perspektif masyarakat 


\section{Padi}

Area budi daya padi di Bonto Karaeng dikembangkan oleh para petani pada 1990-an. Varietas padi yang digunakan adalah Memberamo, Ciherang, dan Ciliwung. Lahan dirawat dua kali setahun dengan penggunaan pupuk ZA dan urea.

Dalam hal produksi padi, penanaman 14 paket benih (sekitar $5 \mathrm{~kg}$ ) dapat menghasilkan 70 karung besar padi (sekitar 550 liter $^{2}$ beras) per hektar. Harga beras Rp 6400 per liter, tetapi hanya sedikit petani yang menjual beras karena sebagian besar digunakan untuk konsumsi.

Kendala utama dalam budi daya padi adalah serangan hama (tikus dan burung).

\subsection{Tipologi 2 (desa dengan sistem agroforestri)}

Kopi, kakao, cengkeh, dan buah-buahan adalah tanaman berbasis pohon utama yang dibudidayakan secara luas pada tipologi ini. Pemerintah menyediakan cukup banyak dukungan untuk mempromosikan tanaman-tanaman ini.

\section{$\underline{\text { Kopi }}$}

Kopi adalah salah satu tanaman utama yang dibudidayakan secara luas di desa yang disurvei. Awalnya, masyarakat hanya mengenal kopi lokal (kopi bugis). Untuk meningkatkan budi daya dan produktivitas kopi, pemerintah menyuplai bibit kopi robusta dan arabica selama lebih dari dua dekade (1970-1990-an). Kebanyakan penduduk desa di Pattaneteang, Campaga, dan Borongrappoa bergantung pada produksi kopi (Gambar 37).

Sekarang ini, kopi arabica dan robusta masih ditanam di kebun, walaupun tipe kopi lain seperti kopi bugis masih dibudidayakan. Penanaman kopi biasanya dilakukan dengan cara membuka hutan, semak belukar, dan bekas ladang jagung. Pengaturan jarak tanam bervariasi---2 2 2 m, 2 × 3 m, 3 x 3 m, dan 2,5 x 2,5 m. Pohon kakao, cengkeh, buah, dan kayu juga ditanam tumpang sari dengan intensitas yang berbeda.

Penyiangan dilakukan 1-3 kali per tahun dengan memotong, menyiram, dan mencangkul. Penggunaan pupuk dilakukan dua kali dalam setahun, biasanya pada awal dan akhir musim hujan. Pupuk yang biasa digunakan adalah urea, ZA, KCL, dan pupuk kandang.

Kopi mulai berbuah setelah dua tahun dan menghasilkan buah yang bagus setelah 3-4 tahun. Kopi arabica dipanen dari April hingga Juli sementara kopi robusta dikumpulkan antara Juni dan Agustus. Produksi kopi berkisar dari 350 hingga 400 kg per hektar (kopi kering). Pattaneteang memiliki produktivitas kopi tinggi---produksi kopi arabica bisa mencapai hingga 600 kg per hektar dan $400 \mathrm{~kg}$ per hektar untuk robusta.

Kopi dipasarkan lewat pedagang di desa yang kemudian menjual kopi itu ke kota terdekat atau di Makassar. Para pedagang berasal dari masyarakat setempat atau dari luar daerah (Gowa dan Jeneponto contohnya). Harga eceran buah kering berkisar dari Rp 12000 hingga Rp 17000 per kilogram. Harga eceran buah segar lebih murah daripada buah kopi kering.

Kendala utama dalam budi daya kopi adalah:

\footnotetext{
${ }^{2}$ Liter biasanya digunakan untuk mengukur beberapa produk pertanian seperti padi, lada, dan cengkeh.
} 
- Biji kopi kering dipanen di musim hujan

- Harga eceran rendah untuk kopi arabica, karena buah segar dijual tepat setelah panen tanpa dikeringkan (di Pattaneteang)

- Hama dan penyakit: penggerek batang, babi hutan liar, monyet, tupai, dan oposum.

- Sulit untuk menumbuhkan kopi di daerah pegunungan (Borongrappoa).

\section{$\underline{\text { Kakao }}$}

Saat ini kakao adalah tanaman yang penting di Campaga, Balangpesoang, dan Kayu Loe. Di Campaga, kakao mulai dibudidayakan secara luas pada 1980-an ketika pemerintah menyediakan bibit kepada para petani. Sekarang, kebanyakan petani menumbuhkan bibit mereka sendiri sementara sebgaian petani lain masih mendapatkan bibit dari Dinas Perkebunan. Beberapa petani juga membeli bibit di luar desa dengan harga sekitar Rp 1000 per bibit (setinggi $15 \mathrm{~cm}$ ), atau buah dengan harga Rp 250 per buah. Jarak tanam diatur secara bervariasi---4 x 4 m, 3 x 4 m, 4 x 5 m, 2 x 2 m, 3 x 3 m, dan 3,5 x 3,5 m. Para petani menanam secara tumpang sari kakao dengan kopi, pohon buah dan kayu dengan intensitas yang berbeda.

Tanaman kakao dirawat tiga tahun sekali dengan menyiram, menyiangi, dan mencangkul. Beberapa petani menggunakan pupuk, sementara petani lain tidak melakukan itu. Pupuk (urea, ZA, atau pupuk organik cair) digunakan sekali dalam setahun. Namun, kondisi ini berubah menjadi dua kali dalam setahun langsung setelah pohon berbuah. Pemangkasan batang juga dilakukan dua kali dalam setahun.

Produksi petani kakao kecil bervariasi, bergantung pada umur tanaman dan tingkat perawatan, tetapi berkisar antara 100-350 kg per musim. Harga eceran kakao kering berfluktuasi antara Rp 16000 hingga 18000 per kilogram. Para petani menjual kakao di kota dan kepada para pedagang yang datang ke desa untuk membeli kakao.

Ancaman utama terhadap tanaman ini adalah penyakit busuk buah (Phytophthora palmivora), hama penggerak batang kakao, tikus dan hama lainnya. Pengetahuan petani untuk mengelola hama dan penyakit masih cukup terbatas, maka meningkatkan kapasitas mereka dalam konteks ini dirasakan penting untuk pengendalian hama.

\section{Kayu Loe 2012}

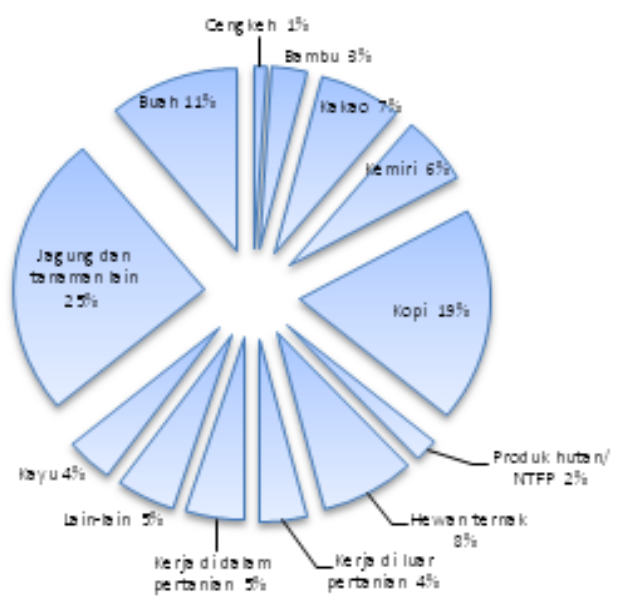

Bonto Karaeng 2012

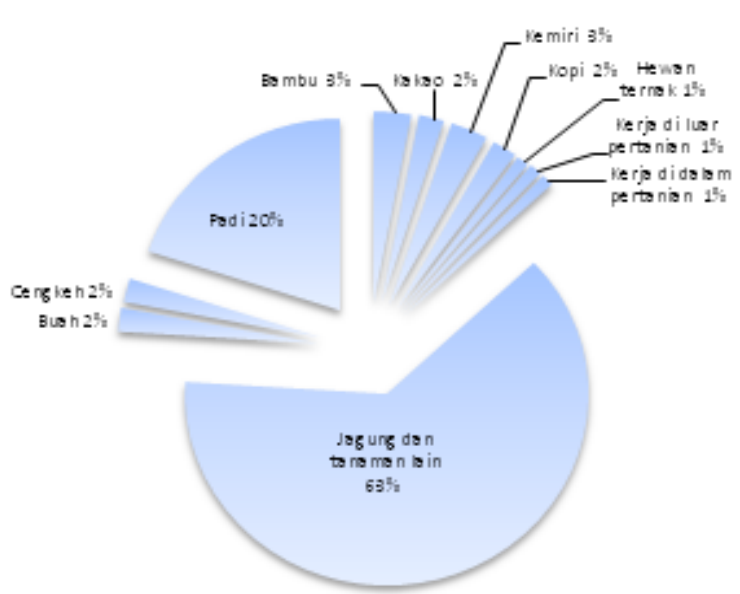

Gambar 37. Opsi mata pencaharian terkini di Pattaneteang dan Campaga berdasarkan perspektif masyarakat 


\section{Cengkeh}

Desa Pattaneteang, Balangpesoang, Campaga, dan Borongrappoa bergantung pada perkebunan cengkeh sebagai opsi mata pencaharian utama mereka dan cengkeh merupakan komponen utama perkebunan petani skala kecil (Gambar 38). Para petani mulai menanam cengkeh pada 1970-an dan budi daya cengkeh menyebar luas pada awal 1980-an.

Ada beberapa tipe cengkeh di Pattaneteang seperti Sansibar, Sikotok, dan Siputih (cengkeh Ambon). Banyak petani yang membeli bibit dan cengkeh di daerah Banyorang dan juga di Bulukumba. Bibit dihargai sekitar Rp 5000 (setinggi 25 cm) dan Rp 10000 (setinggi $50 \mathrm{~cm}$ ). Lainnya, beberapa orang menumbuhkan sendiri bibit cengkeh mereka.

Pengaturan jarak dibuat bervariasi---6 6 × 6 m, 6 × 7 m, 7 x 7 m, dan 8 × 8 m---dengan lubang tanam sebesar 70 x 70 x $70 \mathrm{~cm}$ atau 100 x 100 x $100 \mathrm{~cm}$. Pada umumnya, kebanyakan petani tidak menggunakan pupuk di perkebunan cengkeh mereka dan perawatan dilakukan dua hingga tiga kali dalam setahun melalui penyiraman, pembersihan, dan pencangkulan. Beberapa petani menggunakan pupuk urea, SP36, KCL, atau pupuk kandang dua kali dalam setahun.

Tanaman cengkeh mulai berbuah pada usia lima tahun dan menghasilkan buah yang baik pada usia 5-7 tahun. Panen biasanya dilakukan dari Juli hingga Oktober (50 liter atau 25 kilogram buah segar per pohon). Cengkeh yang sudah dewasa hingga berusia 15-20 tahun dapat menghasilkan \pm 200 liter atau 100 kilogram buah segar per pohon. Di Pattaneteang, cengkeh dijual kebanyakan di luar desa, biasanya di pasar di Kecamatan Banyoran. Sementara di Balangpesoang, cengkeh dijual ke pedagang di desa atau ke pasar di Bulukumba dan Makassar. Harga eceran buah segar adalah Rp 45000 per kilogram dan Rp 125000 per kilogram untuk buah kering.

Kendala utamanya adalah:

- Serangan hama penggerek batang selama 10 tahun terakhir

- Tidak ada musim panen spesifik; pohon berbuah tergantung cuaca. Dalam lima tahun terakhir di Pattaneteang, hanya ada dua tahun musim panen cengkeh

- Harga cengkeh yang rendah pada musim hujan

\section{Buah-buahan}

Balangpesoang merupakan masyarakat yang sukses menghasilkan buah-buahan dan budi daya buah juga memberikan kontribusi terhadap mata pencaharian masyarakat di Borongrappoa dan Kayu Loe. Buah-buahan yang umum ditanam adalah petai, duku, durian, rambutan, manggis, pisang, alpukat, nangka, dan 'labbusiang'.

Masyarakat Balangpesoang mulai menanam beragam buah seperti rambutan, manggis, durian, durian cipaku, dan durian montong pada 1990-an. Kondisi ini disebabkan oleh serangan hama pada tanaman kakao yang mendorong para petani untuk mengganti kakao dengan pohon buah.

Pohon buah ditanam tumpang sari dengan cengkeh dan diberi jarak tanam 8 x $8 \mathrm{~m}$. Para petani menggunakan bibit unggul atau bibit cangkok. Penyiangan dan pemupukan dilakukan secara rutin.

Kendala utamanya adalah

- Pemasaran, terutama dalam musim panen besar

- Hama dan penyakit---jamur pada daun, jamur batang dan buah

- Buah yang jatuh pada musim hujan. 


\section{Borongrappoa 2012}

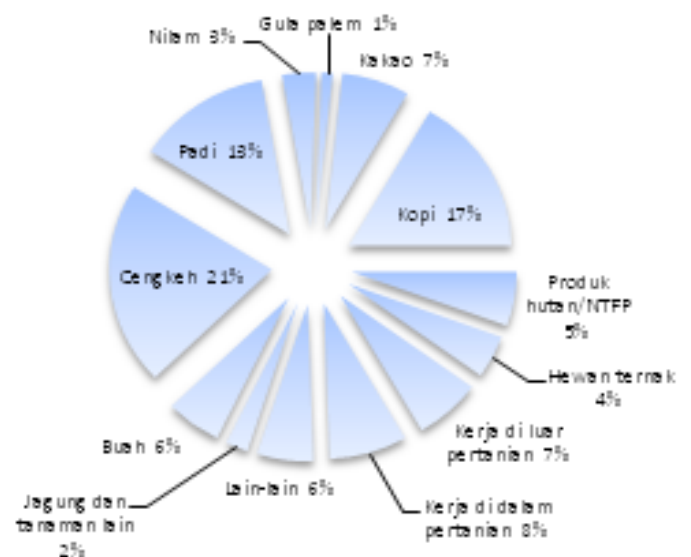

Balangpesoang 2012

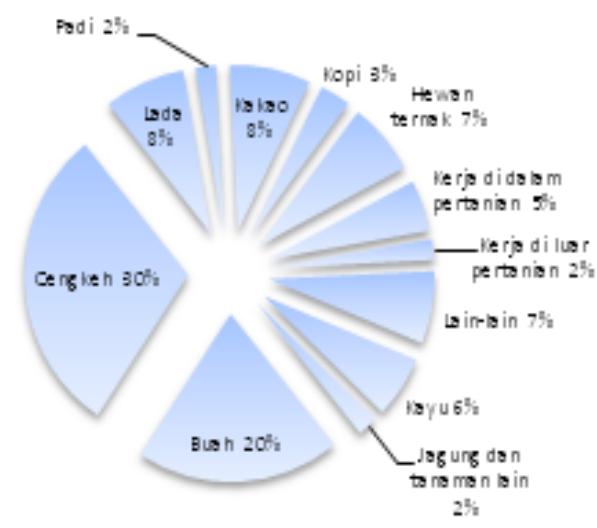

Gambar 38. Opsi mata pencaharian terkini di Borongrappoa dan Balangpesoang berdasarkan perspektif masyarakat

\subsection{Tipologi 3 (desa dengan sistem berbasis kayu)}

Ketertarikan pada komoditas kayu meningkat di beberapa bagian pada tipologi ini. Kelapa, gula kelapa, padi, dan jagung juga memberikan kontribusi signifikan terhadap kesejahteraan masyarakat (Gambar 39).

\section{$\underline{\text { Kayu }}$}

Ketertarikan petani dalam menanam pohon kayu muncul dari informasi yang berasal dari pihak luar bahwa pohon kayu akan menjadi opsi yang menguntungkan. Pada 2005, Desa Tugondeng mulai menanam pohon kayu menggunakan bibit yang berasal dari Departemen Kehutanan, juga beberapa jenis pohon kayu lokal dari alam liar. Pada 2011/2012, Departemen Pertanian dan Departemen Kehutanan menyediakan pohon jati, mahoni, suren, jati putih, dan sengon muda kepada para petani di Tugondeng dan Tana Towa; namun, pohon-pohon ini belum menjadi sumber pendapatan utama. Sekarang ini, pusat produksi kayu berlokasi di tempat lainnya di Kecamatan Herlang.

\section{$\underline{\text { Padi }}$}

Padi adalah tanaman penting untuk masyarakat setempat, terutama di Tana Towa di mana varietas padi lokal dan hibrida dibudidayakan dengan dukungan dari pemerintah. Varietas lokal adalah padi hitam (pare leleng kuru), padi merah, padi ketan, padi biasa (pare sahe), dan pemerintah menyediakan padi hibrida PB-5. 
Tugondeng 2012

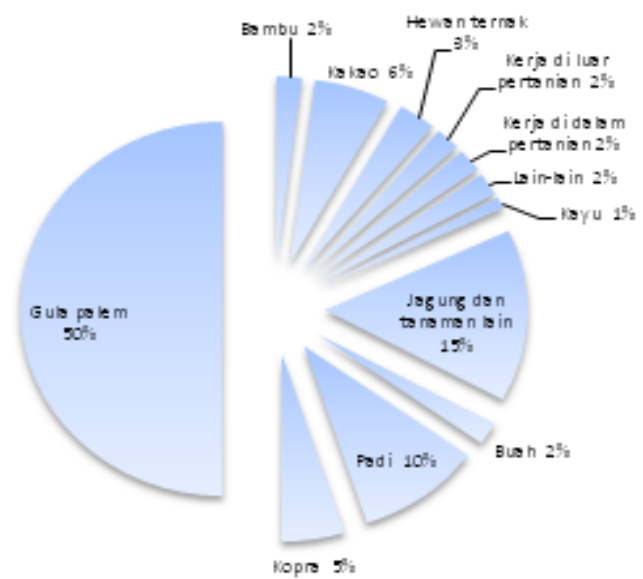

Tana Towa 2012

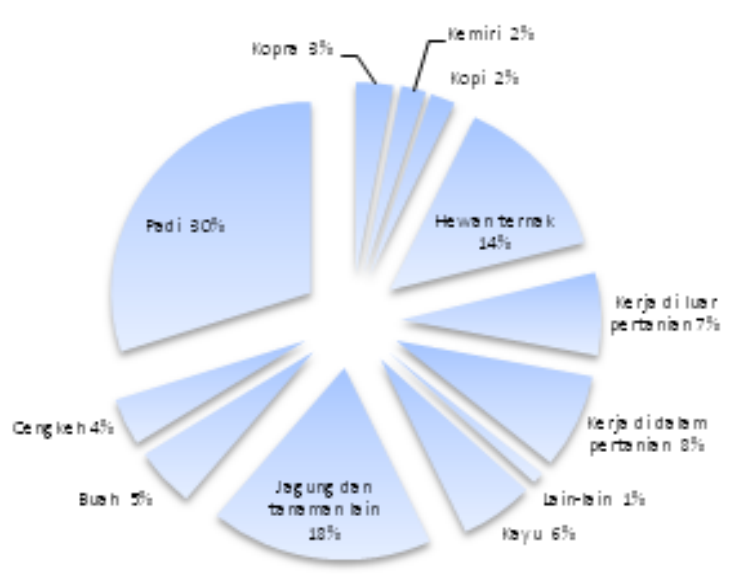

Gambar 39. Opsi mata pencaharian terkini di Tugondeng dan Tana Towa berdasarkan perspektif masyarakat

Para petani Tana Towa menggunakan pupuk dua kali dalam setahun menggunakan triple superphosphate (TSP) dan urea (10 karung untuk satu kali musim tanam). Padi yang dipanen biasanya dipakai untuk konsumsi pribadi. Ancaman utama pada budi daya padi adalah hama--wereng, tikus, babi hutan, dan penggerek batang---dan penyakit.

\section{Jagung dan tanaman lain}

Para petani menanam jagung hibrida yang didapatkan dari pemerintah dua kali dalam setahun. Jagung hibrida menghasilkan maksimum lima ton per hektar (jagung yang dikeringkan). Penyiangan dilakukan dua kali dalam setahun dan ladang dipupuk dengan tujuh karung pupuk campuran (urea, TSP, ZA, NSPK) per hektar. Sekarang ini, para petani menjual jagung ke pasar/pedagang desa atau ke pasar di Bulukumba; jagung dihargai sekitar Rp 1100 per kilogram. Hama (tikus) adalah kendala utama.

\section{Kelapa dan qula kelapa}

Kelapa adalah sumber daya alam yang penting, terutama di Desa Tugondeng di mana setengah penggunaan lahan didominasi oleh agroforestri kelapa. Pada 1980-an banyak petani yang menanam kelapa menggunakan bibit hibrida yang berasal dari program dukungan pemerintah. Sekarang ini, bibit kelapa disediakan oleh pemerintah dengan harga Rp 1500 per bibit (setinggi $50 \mathrm{~cm}$ ); para penduduk desa juga melakukan budi daya bibit sendiri. Ternyata lebih mudah untuk menghasilkan bibit kelapa dengan mengambil buahnya langsung dan menanam buah itu di bedeng atau kantong polietilene selama tiga bulan, dan sesudah itu, buah siap ditanam di ladang.

Penanaman kelapa menggunakan pengaturan jarak 8 x 8 m. Pupuk digunakan dua kali dalam setahun, menggunakan campuran TSP, urea, ZA, dan kieserite sebanyak 4 karung per hektar (didistribusikan dengan tangan). Kelapa hibrida mulai berbuah pada usia 4 tahun dan puncak pohon berbuah adalah pada usia 10 tahun. Kelapa dipanen setiap 4 bulan atau 3 kali dalam setahun, dan dapat menghasilkan sekitar 3000 buah per hektar. Sekitar 7 buah kelapa akan menghasilkan 2 kg kopra segar. Masyarakat setempat menjual kopra ke pedagang desa dengan harga Rp 2100 per kilogram (kopra segar) dan Rp 5000 per kilogram (kopra kering).

Banyak petani yang juga menghasilkan gula kelapa di desa Tugondeng. Para petani menyadap pohon kelapa pada pagi hari (06:00 - 07:30) dan sore hari (15:00 - 17:00). Pada setiap pohon 
kelapa, para petani menyadap 2-3 tunas muda (bakal bunga) yang menghasilkan sekitar 2 liter nira kelapa per pohon yang digunakan untuk membuat gula kelapa. Umumnya para petani menggunakan kayu bakar untuk menghasilkan gula kelapa.

Para petani menjual gula kelapa mereka kepada para pedagang yang datang ke desa. Para pedagang ini mengemas ulang gula kelapa untuk pasar besar di Makassar. Harga gula kelapa bagi para pengumpul ini dapat mencapai Rp 8000 per kilogram, cukup tinggi dibandingkan dengan harga kopra. Pendapatan bruto untuk petani kopra dapat mencapai setinggi Rp 2 juta per bulan dari lahan 1 hektar dan gula kelapa dapat menghasilkan setinggi Rp 3 juta per bulan dari lahan 1 hektar.

Kendala utama dalam pengelolaan perkebunan kelapa sekarang adalah serangan babi hutan yang sering terjadi, pohon kelapa tua atau nyaris mati, juga fluktuasi harga kopra dan gula kelapa di tingkat petani.

\subsection{Indikator penting mata pencaharian berdasarkan survei rumah tangga}

\subsubsection{Sumber pendapatan}

Rumus dasar tentang pendapatan dari wiraswasta (dalam pertanian atau bisnis) adalah:

$$
I=\sum_{i=i}^{n} p_{i} y_{i}-\sum_{j=1}^{m} q_{j} v_{j}
$$

Pendapatan (income, $I$ ) adalah nilai bruto (harga dikalikan kuantitas semua produk $n$ ) dikurangi biaya total (harga dikalikan kuantitas semua masukan $m$ yang dibeli), contohnya pupuk, benih, peralatan, tenaga kerja yang disewa (Angelsen dan Lund 2011).

Rata-rata pendapatan per tahun per rumah tangga untuk petani Tipologi 1 lebih rendah dibandingkan dengan 2 tipologi lainnya. Terdapat perbedaan pendapatan yang cukup tinggi di antara ketiga tipologi ini, begitu pun dengan sumber pendapatan utama petani.

Perhitungan pendapatan yang dilakukan, termasuk nilai semua komoditas yang dikonsumsi. Pada penelitian ini, sebesar 62\% pendapatan berasal dari sawah untuk petani pada Tipologi 2 merupakan pendapatan yang konsumsi (consumable income). Namun, pada umumnya pendapatan berasal dari tanaman berjangka pendek (cash crops).

Untuk petani Tipologi 1, sumber pendapatan utama berasal dari ladang jagung (28,3\%), kiriman uang (20,6\%), dan buruh upahan (12,2\%) (Tabel 5). Untuk petani Tipologi 2, sumber pendapatan utama adalah kebun campur/agroforestri (29,5-31,8\%) dan usaha (13,4\%-32,7\%). Sumber-sumber pendapatan lain berasal dari sawah, cengkeh, dan buruh upahan. Untuk petani Tipologi 3, rata-rata total pendapatan per tahun per rumah tangga menempati peringkat tertinggi. Sumber utama pendapatan para petani ini berasal dari agroforestri kelapa (23,2\%). Sumber pendapatan lain adalah usaha (23,7\%) dan kebun campur/agroforestri (18,3\%). 
Tabel 5. Rata-rata pendapatan masyarakat berdasarkan sumber pendapatan di Sulawesi Selatan pada tahun 2012

\begin{tabular}{|c|c|c|c|c|c|c|c|c|c|c|c|c|}
\hline \multirow{4}{*}{ Sumber pendapatan } & \multicolumn{8}{|c|}{ Rata-rata pendapatan dalam rumah tangga } & \multicolumn{4}{|c|}{ Pendapatan per kapita } \\
\hline & \multirow{2}{*}{\multicolumn{2}{|c|}{$\begin{array}{c}\text { Lahan terdegradasi } \\
\text { Desa Kayu Loe }\end{array}$}} & \multicolumn{4}{|c|}{ Sistem agroforestri } & \multirow{2}{*}{\multicolumn{2}{|c|}{$\begin{array}{c}\text { Sistem berbasis kayu } \\
\text { Desa Tugondeng }\end{array}$}} & \multirow{3}{*}{$\begin{array}{c}\begin{array}{c}\text { Lahan } \\
\text { terdegradasi }\end{array} \\
\text { Kayu Loe } \\
\text { Rupiah }\end{array}$} & \multicolumn{2}{|c|}{ Sistem agroforestri } & \multirow{3}{*}{$\begin{array}{c}\begin{array}{c}\text { Sistem berbasis } \\
\text { kayu }\end{array} \\
\text { Tugondeng } \\
\text { Rupiah }\end{array}$} \\
\hline & & & \multicolumn{2}{|c|}{ Desa Campaga } & \multicolumn{2}{|c|}{ Desa Balangpesoang } & & & & Campaga & Balangpesoang & \\
\hline & Rupiah & $\%$ & Rupiah & $\%$ & Rupiah & $\%$ & Rupiah & $\%$ & & Rupiah & Rupiah & \\
\hline 1. On-farm/pertanian & 5.877 .350 & 45,2 & 12.470 .985 & 52,3 & 8.377 .393 & 39,4 & 21.764 .539 & 60,3 & 1.388 .350 & 3.170 .589 & $2.148 .049,60$ & $5.351 .935,90$ \\
\hline Sawah & - & - & 2.519 .550 & 10,6 & 0 & - & 823.217 & 2,3 & - & 640.564 & 0 & 202.430 \\
\hline Ladang jagung & 3.688 .182 & 28,3 & 59.383 & 0,2 & 0 & - & 448.167 & 1,2 & 871.224 & 15.097 & 0 & 110.205 \\
\hline Agroforestri kakao & 284.208 & 2,2 & 153.817 & 0,6 & 394.233 & 1,9 & 4.995 .860 & 13,8 & 67.136 & 39.106 & 101.085 & 1.228 .490 \\
\hline Kebun campur (agroforestri) & 334.467 & 2,6 & 7.045 .085 & 29,5 & 7.064 .477 & 33,2 & 6.604 .790 & 18,3 & 79.008 & 1.791 .123 & 1.811 .404 & 1.624 .129 \\
\hline Agroforestri kelapa & - & - & - & - & 0 & - & 8.373 .406 & 23,2 & - & 0 & 0 & 2.059 .034 \\
\hline Agroforestri cengkeh & - & - & 2.179 .617 & 9,1 & 526.683 & 2,5 & - & - & - & 554.140 & 135.047 & - \\
\hline Kebun kayu & - & - & - & - & 0 & - & 84.783 & 0,2 & - & 0 & 0 & 20.848 \\
\hline Agroforestri kopi & 1.059 .110 & 8,1 & 5.550 & 0 & 0 & - & - & - & 250.183 & 1.411 & 0 & - \\
\hline Pertanian lainnya & 511.383 & 3,9 & 507.983 & 2,1 & 392.000 & 1,8 & 434.317 & 1,2 & 120.799 & 129.148 & 100.513 & 106.799 \\
\hline 2. Off-farm/non-pertanian & 7.134 .400 & 54,8 & 11.378 .300 & 47,7 & 12.869 .500 & 60,6 & 14.314 .167 & 39,7 & 1.685 .291 & 2.892 .788 & 3.299 .872 & 3.519 .877 \\
\hline Kayu bakar & 669.933 & 5,1 & 884.000 & 3,7 & 918.900 & 4,3 & 607.000 & 1,7 & 158.252 & 224.746 & 235.615 & 149.262 \\
\hline Buruh upahan & 1.582 .133 & 12,2 & 2.292 .667 & 9,6 & 2.032 .667 & 9,6 & 1.038 .500 & 2,9 & 373.732 & 582.881 & 521.197 & 255.369 \\
\hline Usaha & 636.667 & 4,9 & 3.186 .000 & 13,4 & 6.942 .933 & 32,7 & 8.560 .667 & 23,7 & 150.394 & 810.000 & 1.780 .239 & 2.105 .082 \\
\hline Profesional & 454.000 & 3,5 & 1.390 .667 & 5,8 & 360.000 & 1,7 & 828.000 & 2,3 & 107.244 & 353.559 & 92.308 & 203.607 \\
\hline Lainnya & 1.111 .667 & 8,5 & 3.131 .633 & 13,1 & 2.141 .667 & 10,1 & 3.140 .000 & 8,7 & 262.598 & 796.178 & 549.145 & 772.131 \\
\hline Kiriman & 2.680 .000 & 20,6 & 493.333 & 2,1 & 473.333 & 2.2 & 140.000 & 0,4 & 633.071 & 125.424 & 121.368 & 34.426 \\
\hline 3. Total pendapatan per tahun & 13.011 .750 & 100 & 23.849 .285 & 100 & 21.246 .893 & 100 & 36.078 .706 & 100 & 3.073 .642 & 6.063 .378 & 5.447 .921 & 8.871 .813 \\
\hline Pendapatan per kapita per hari (Rp) & & & & & & & & & 8.491 & 18.034 & 15.963 & 25.550 \\
\hline Pendapatan per kapita per hari (USD) & & & & & & & & & 0.96 & 2.05 & 1.81 & 2.9 \\
\hline
\end{tabular}


Gambar 40 menunjukkan bahwa sumber pendapatan per rumah tangga untuk petani Tipologi 1 adalah hampir sama antara kegiatan nonpertanian (55\%) dan pertanian (45\%). Untuk petani Tipologi 2, terdapat sedikit perbedaan antara kedua sumber tersebut. Untuk petani Tipologi 3, sumber pendapatan dari kegiatan pertanian (60\%) lebih tinggi dibandingkan dengan kegiatan nonpertanian (40\%)

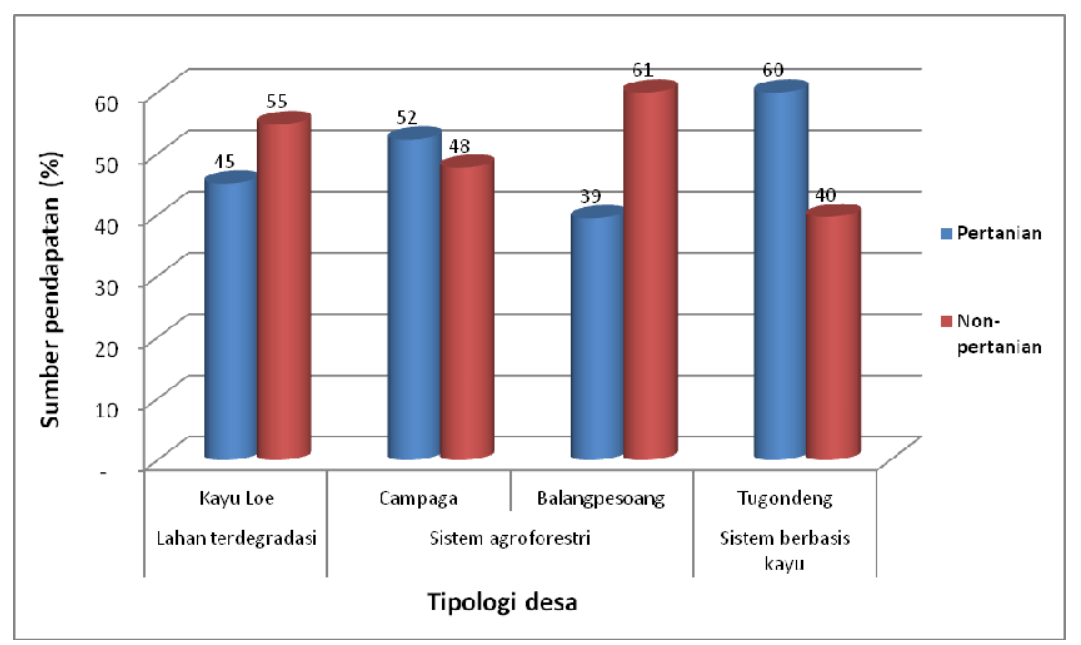

Gambar 40. Sumber pendapatan di Sulawesi Selatan pada 2012

\subsubsection{Pendapatan per kapita}

Pendapatan per kapita per hari untuk petani Tipologi 1 lebih rendah dibandingkan dengan kedua Tipologi lain. Petani pada Tipologi 1 termasuk miskin karena nilai pendapatan per kapita per hari berada di bawah garis kemiskinan internasional (Gambar 41).

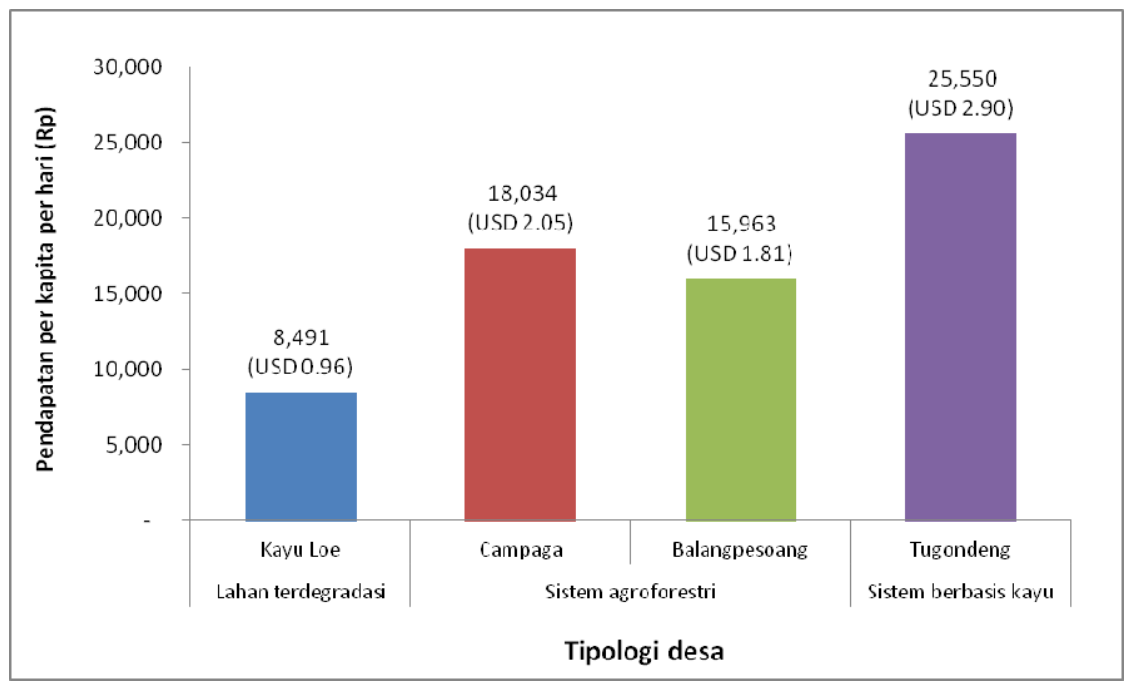

Gambar 41. Rata-rata pendapatan per kapita per hari masyarakat di Sulawesi Selatan pada 2012 


\subsubsection{Kepemilikan lahan}

Rata-rata kepemilikan tanah per rumah tangga untuk petani Tipologi 3 (2,09 ha) lebih besar dibandingkan dengan kedua tipologi lainnya (Gambar 42). Komposisi kepemilikan tanah juga berbeda-beda di dalam ketiga tipologi (Tabel 6).

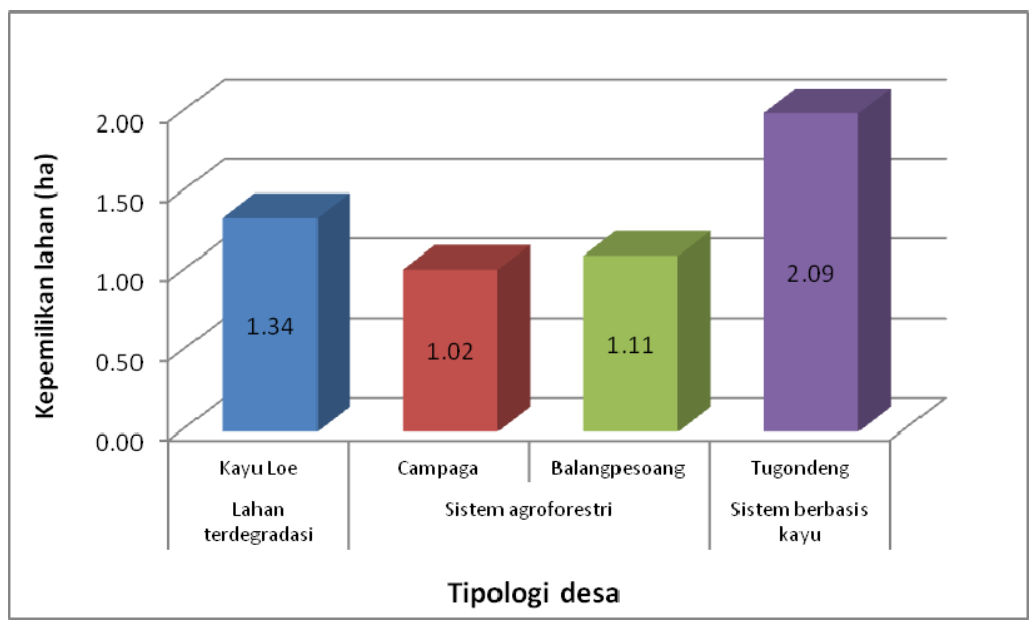

Gambar 42. Distribusi kepemilikan lahan rata-rata per rumah tangga di Sulawesi Selatan

Tabel 6. Distribusi luas penguasaan lahan rata-rata berdasarkan penggunaan lahan di Sulawesi Selatan

\begin{tabular}{|c|c|c|c|c|c|c|c|c|c|c|}
\hline \multirow{2}{*}{$\begin{array}{l}\text { Tipologi } \\
\text { desa }\end{array}$} & \multirow[b]{2}{*}{ Desa } & \multicolumn{9}{|c|}{ Rata-rata kepemilikan lahan berdasarkan penggunaan lahan (ha) } \\
\hline & & Sawah & $\begin{array}{l}\text { Ladang } \\
\text { jagung }\end{array}$ & $\begin{array}{c}\text { Agroforestri } \\
\text { kakao }\end{array}$ & $\begin{array}{l}\text { Kebun } \\
\text { campur }\end{array}$ & $\begin{array}{l}\text { Kebun } \\
\text { kayu }\end{array}$ & $\begin{array}{l}\text { Agroforestri } \\
\text { cengkeh }\end{array}$ & $\begin{array}{c}\text { Agroforestri } \\
\text { kelapa }\end{array}$ & $\begin{array}{c}\text { Agroforestri } \\
\text { kopi }\end{array}$ & $\begin{array}{l}\text { Semak } \\
\text { belukar }\end{array}$ \\
\hline $\begin{array}{l}\text { Lahan } \\
\text { terdegradasi }\end{array}$ & Kayu Loe & 0,00 & 0,86 & 0,05 & 0,14 & 0,00 & 0,00 & 0,00 & 0,29 & 0 \\
\hline \multirow{2}{*}{$\begin{array}{l}\text { Sistem } \\
\text { agroforestri }\end{array}$} & Campaga & 0,20 & 0,01 & 0,03 & 0,65 & 0,00 & 0,08 & 0,00 & 0,04 & 0 \\
\hline & Balangpesoang & 0,00 & 0,00 & 0,07 & 0,83 & 0,00 & 0,20 & 0,00 & 0,00 & 0 \\
\hline $\begin{array}{l}\text { Sistem } \\
\text { berbasis } \\
\text { kayu }\end{array}$ & Tugondeng & 0,18 & 0,04 & 0,32 & 0,65 & 0,22 & 0,00 & 0,68 & 0,00 & 0,01 \\
\hline
\end{tabular}




\section{Kesimpulan}

Hasil diskusi kelompok di dalam 3 tipologi menunjukkan bahwa ada perbedaan yang cukup jelas dalam hal opsi mata pencaharian, tanaman pohon, dan pengelolaan pertanian. Perbedaan-perbedaan ini dipengaruhi oleh perbedaan historis dari pengelolaan lahan, penggunaan lahan, dan dinamika penggunaan lahan, serta akses ke pasar.

Di Kayu Loe dan Bonto Karaeng (Tipologi 1), ladang jagung meningkat secara signifikan selama 40 tahun terakhir, sementara budi daya kemiri dan tutupan hutan menurun. Situasi ini terkait dengan lonjakan jagung hibrida pada periode yang sama. Lebih jauh lagi, lahan di Kayu Loe dan Bonto Karaeng dirusak oleh erosi yang terus berlanjut akibat praktik pengelolaan lahan setempat yang tidak layak (budi daya jagung sangat intensif).

Di Pattaneteang dan Campaga (Tipologi 2), agroforestri kopi dan cengkeh meningkat cukup signifikan selama 40 tahun terakhir, bersamaan dengan penurunan budi daya jagung dan tutupan hutan. Area sawah di lembah tetap tidak berubah karena konversi lahan di sana dihindari. Ladang jagung menghilang pada 2012. Kondisi ini mencerminkan lonjakan pada agroforestri kopi dan cengkeh. Para petani di Kabupaten Bantaeng dan Bulukumba telah cukup lama mempraktikkan sistem agroforestri kompleks. Kopi, kakao, dan cengkeh dicampur dengan beragam tipe tanaman dan pohon buah. Praktik pertanian dipengaruhi oleh kebijakan pemerintah yang telah memperkenalkan tanaman per kebunan. Terbatasnya jumlah lahan yang dimiliki para petani memaksa mereka untuk menggunakan sistem agroforestri.

Di Tugondeng dan Tana Towa (Tipologi 3), ditemukan perbedaan dalam penggunaan lahan. Di Tugondeng, area kelapa meningkat cukup signifikan selama 40 tahun terakhir dan sekarang menjadi sumber daya alam utama. Secara bersamaan, budi daya jagung menurun dan area sagu dan semak belukar menghilang pada 2012 (di Tana Towa hal sebaliknya terjadi). Hampir semua bentuk penggunaan lahan tidak berubah selama 40 tahun terakhir karena adanya hukum adat yang kuat di desa itu. Hukum adat sangat efektif dalam melestarikan area hutan lindung dari perambahan. Ada sedikit peningkatan dalam jumlah pemukiman dan ladang jagung karena konversi lahan semak belukar. Baru-baru ini, sistem berbasis kayu telah diintegrasikan ke dalam praktik pertanian yang ada. Sistem agroforestri yang dipraktikkan di pada tipologi ini mirip dengan yang terjadi di Tipologi 2. Namun, perkembangan perkebunan pohon kayu petani skala kecil di desa-desa ini meningkatkan minat terhadap kayu dan menjadikannya mata pencaharian yang populer. Daerah ini cukup terkenal sebagai sumber kayu alam (biti atau vitex, jati lokal, dan lain-lain) di Sulawesi Selatan, dan daerah ini juga menjadi penerima keuntungan dari kebijakan pemerintah yang mendorong lonjakan komoditas kayu.

Kondisi rumah para petani dapat digunakan untuk memperkirakan kesejahteraan mereka. Kondisi rumah para petani pada Tipologi 1 paling buruk dibandingkan dengan rumah para petani pada Tipologi 2 dan 3, dengan kondisi rumah yang hampir sama. Hal yang sama juga terjadi pada tingkat pendidikan pada Tipologi 1 dibandingkan dengan Tipologi 2 dan 3. Tingkat pendidikan untuk perempuan sedikit lebih rendah daripada laki-laki. Etnis kepala keluarga yang dominan dalam semua tipologi adalah Makassar atau Bugis.

Pada ketiga tipologi, lahan petani dimiliki dan dikelola sendiri, dan didapatkan dari warisan atau pembelian. Sebagian besar lahan pada Tipologi 1 diwariskan dari orangtua suami; pada Tipologi 2, 
umumnya lahan diwariskan dari orangtua suami atau dibeli dari orang lain; dan pada Tipologi 3, sebagian besar lahan dibeli dari orang lain.

Rata-rata pendapatan per tahun per rumah tangga untuk petani Tipologi 1 lebih rendah dibandingkan dengan dua tipologi lain. Sumber pendapatan utama pada Tipologi 1 adalah ladang jagung dan kiriman uang; pada Tipologi 2 dari hasil agroforestri (kebun campur); dan pada Tipologi 3 dari hasil agroforestri kelapa dan usaha.

Pendapatan per kapita per hari petani pada Tipologi 1 lebih rendah dibandingkan dengan 2 tipologi lain. Petani pada Tipologi 1 termasuk miskin karena nilai pendapatan per kapita per hari berada di bawah garis kemiskinan internasional. Nilai pendapatan itu adalah Rp 8491 (US\$ 0,96) pada petani Tipologi 1; Rp 18034 (US\$ 2,05), dan Rp 15963 (US\$ 1,81) pada Tipologi 2; dan Rp 25 550 (US\$ 2,90) pada Tipologi 3.

Rata-rata kepemilikan lahan per rumah tangga untuk petani Tipologi 3 (2,09 ha) lebih besar dibandingkan untuk petani Tipologi 1 dan 2, yaitu 1,34 pada Tipologi 1 dan 1,06 ha pada Tipologi 2. Penggunaan lahan utama untuk petani Tipologi 1 adalah ladang jagung (0,86 ha) dan kebun campur/agroforestri $(0,65-0,80$ ha) untuk petani Tipologi 2. Pada Tipologi 3, agroforestri kelapa (0,68 ha) dan kebun campur/agroforestri (0,65 ha).

\section{Rekomendasi}

- Meningkatkan akses dan pengetahuan petani terhadap bibit berkualitas baik dan dengan harga terjangkau.

- Meningkatkan kegiatan penyuluhan melalui penyediaan materi yang sesuai dan praktik langsung di lapangan. Kembangkan panduan yang bermanfaat untuk teknik budi daya (kopi, kakao, cengkeh), juga penanggulangan hama dan penyakit.

- Memperluas jaringan/teknik pemasaran dan peningkatan kualitas produk untuk mempertahankan harga yang bersaing di pasar. Mendirikan lembaga kredit mikro untuk mendukung pemasaran produk pertanian.

- Mengembangkan dan meningkatkan penyediaan modal kepada para petani untuk dapat mengembangkan bisnis mereka.

- Mendukung peremajaan perkebunan petani skala kecil, seperti kelapa di Tugondeng.

- Dukung pengembangan kapasitas budi daya tanaman berpotensi lainnya, seperti pelatihan budi daya karet.

- Menyediakan tekonologi yang sesuai untuk perbaikan kualitas produk dan diversifikasi tanaman perkebunan. 


\section{Referensi}

Angelsen A, Lund,J-F. Designing the household questionnaire. In: Angelsen A, Larsen HO, Lund JF, Smith-Hall C, Wunder S. 2011. Measuring livelihoods and environmental dependence: methods for research and fieldwork [Mendesain kuesioner rumah tangga. Dalam: Angelsen A, Larsen HO, Lund JF, Smith-Hall C, Wunder S. 2011. Mengukur mata pencaharian dan ketergantungan lingkungan: metode untuk penelitian dan kerja lapangan]. Washington: Earthscan.

Arnold JEM. 2001. Forest and people: 25 years of community forestry [Hutan dan masyarakat: 25 tahun kehutanan masyarakat]. Rome: Food and Agriculture Organization of the United Nations.

Arnold JEM, Bird P. 1999. Forests and the poverty-environment nexus [Hutan dan pertalian kemiskinan-lingkungan]. UNDP/EC Expert Workshop on Poverty and the Environment, Brussels, January 20-21.

BPS. 2008. Sulawesi Selatan Dalam Angka. Makassar, Indonesia: Badan Pusat Statistik Provinsi Sulawesi Selatan.

BPS. 2009. Analisis dan Penghitungan Tingkat Kemiskinan. Indonesia: Badan Pusat Statistik.

BPS. 2010. Statistik Indonesia. Indonesia: Badan Pusat Statistik

BPS. 2012. Bulukumba Dalam Angka. Bulukumba, Indonesia: Badan Pusat Statistik Kabupaten Bulukumba.

BPS. 2012. Statistik Daerah Kabupaten Bantaeng. Bantaeng, Indonesia: Badan Pusat Statistik Kabupaten Bantaeng.

Dinas Perkebunan. 2010. Statistik Perkebunan Tahun 2010. Makassar, Indonesia: Dinas Perkebunan Provinsi Sulawesi Selatan.

Badan Koordinasi Penanaman Modal (BKPMD). 2010. Peta Investasi Produk Unggulan. Makassar, Indonesia: Badan Koordinasi Penanaman Modal Provinsi Sulawesi Selatan.

Roshetko JM, Suyanto, Dewi S, Sunderland T, Purwanto E, Perdana A, Millang S, Yuliani L, Purnomosidhi P, Tarigan J, Martini E, Finlayson R, Dahlia L. 2012. Agroforestry and forestry in Sulawesi: Linking knowledge to action. AgFor-CIDA Annual Report of first year (April 2011-March 2012). Bogor, Indonesia: World Agroforestry Centre (ICRAF) SEA Regional Office.

\section{Situs}

Produksi kakao di Kabupaten Bantaeng and Bulukumba:

http://regionalinvestment.bkpm.go.id/newsipid/id/commodityarea.php?ia=73\&ic=3

Produksi kelapa/cengkeh di Kabupaten Bantaeng and Bulukumba:

http://regionalinvestment.bkpm.go.id/newsipid/id/commodityarea.php?ia=73\&ic=85

Produksi kopi di Kabupaten Bantaeng and Bulukumba:

http://regionalinvestment.bkpm.go.id/newsipid/id/commodityarea.php?ic=62\&ia=73 



\section{WORKING PAPERS IN THIS SERIES}

\section{5}

1. Agroforestry in the drylands of eastern Africa: a call to action

2. Biodiversity conservation through agroforestry: managing tree species diversity within a network of community-based, nongovernmental, governmental and research organizations in western Kenya.

3. Invasion of prosopis juliflora and local livelihoods: Case study from the Lake Baringo area of Kenya

4. Leadership for change in farmers organizations: Training report: Ridar Hotel, Kampala, 29th March to 2nd April 2005.

5. Domestication des espèces agroforestières au Sahel : situation actuelle et perspectives

6. Relevé des données de biodiversité ligneuse: Manuel du projet biodiversité des parcs agroforestiers au Sahel

7. Improved land management in the Lake Victoria Basin: TransVic Project's draft report.

8. Livelihood capital, strategies and outcomes in the Taita hills of Kenya

9. Les espèces ligneuses et leurs usages: Les préférences des paysans dans le Cercle de Ségou, au Mali

10. La biodiversité des espèces ligneuses: Diversité arborée et unités de gestion du terroir dans le Cercle de Ségou, au Mali

\section{6}

11. Bird diversity and land use on the slopes of Mt. Kilimanjaro and the adjacent plains, Tanzania

12. Water, women and local social organization in the Western Kenya Highlands

13. Highlights of ongoing research of the World Agroforestry Centre in Indonesia

14. Prospects of adoption of tree-based systems in a rural landscape and its likely impacts on carbon stocks and farmers' welfare: The FALLOW Model Application in Muara Sungkai, Lampung, Sumatra, in a 'Clean Development Mechanism' context

15. Equipping integrated natural resource managers for healthy Agroforestry landscapes.

17. Agro-biodiversity and CGIAR tree and forest science: approaches and examples from Sumatra.

18. Improving land management in eastern and southern Africa: A review of policies.

19. Farm and household economic study of Kecamatan Nanggung, Kabupaten Bogor, Indonesia: A socio-economic base line study of Agroforestry innovations and livelihood enhancement.

20. Lessons from eastern Africa's unsustainable charcoal business.

21. Evolution of RELMA's approaches to land management: Lessons from two decades of research and development in eastern and southern Africa

22. Participatory watershed management: Lessons from RELMA's work with farmers in eastern Africa.

23. Strengthening farmers' organizations: The experience of RELMA and ULAMP.

24. Promoting rainwater harvesting in eastern and southern Africa.

25. The role of livestock in integrated land management.

26. Status of carbon sequestration projects in Africa: Potential benefits and challenges to scaling up.

27. Social and Environmental Trade-Offs in Tree Species Selection: A Methodology for Identifying Niche Incompatibilities in Agroforestry [Appears as AHI Working Paper no. 9]

28. Managing tradeoffs in agroforestry: From conflict to collaboration in natural resource management. [Appears as AHI Working Paper no. 10]

29. Essai d'analyse de la prise en compte des systemes agroforestiers pa les legislations forestieres au Sahel: Cas du Burkina Faso, du Mali, du Niger et du Senegal.

30. Etat de la recherche agroforestière au Rwanda etude bibliographique, période 1987-2003 


\section{7}

31. Science and technological innovations for improving soil fertility and management in Africa: A report for NEPAD's Science and Technology Forum.

32. Compensation and rewards for environmental services.

33. Latin American regional workshop report compensation.

34. Asia regional workshop on compensation ecosystem services.

35. Report of African regional workshop on compensation ecosystem services.

36. Exploring the inter-linkages among and between compensation and rewards for ecosystem services CRES and human well-being

37. Criteria and indicators for environmental service compensation and reward mechanisms: realistic, voluntary, conditional and pro-poor

38. The conditions for effective mechanisms of compensation and rewards for environmental services.

39. Organization and governance for fostering Pro-Poor Compensation for Environmental Services.

40. How important are different types of compensation and reward mechanisms shaping poverty and ecosystem services across Africa, Asia \& Latin America over the Next two decades?

41. Risk mitigation in contract farming: The case of poultry, cotton, woodfuel and cereals in East Africa.

42. The RELMA savings and credit experiences: Sowing the seed of sustainability

43. Yatich J., Policy and institutional context for NRM in Kenya: Challenges and opportunities for Landcare.

44. Nina-Nina Adoung Nasional di So! Field test of rapid land tenure assessment (RATA) in the Batang Toru Watershed, North Sumatera.

45. Is Hutan Tanaman Rakyat a new paradigm in community based tree planting in Indonesia?

46. Socio-Economic aspects of brackish water aquaculture (Tambak) production in Nanggroe Aceh Darrusalam.

47. Farmer livelihoods in the humid forest and moist savannah zones of Cameroon.

48. Domestication, genre et vulnérabilité : Participation des femmes, des Jeunes et des catégories les plus pauvres à la domestication des arbres agroforestiers au Cameroun.

49. Land tenure and management in the districts around Mt Elgon: An assessment presented to the Mt Elgon ecosystem conservation programme.

50. The production and marketing of leaf meal from fodder shrubs in Tanga, Tanzania: A pro-poor enterprise for improving livestock productivity.

51. Buyers Perspective on Environmental Services (ES) and Commoditization as an approach to liberate ES markets in the Philippines.

52. Towards Towards community-driven conservation in southwest China: Reconciling state and local perceptions.

53. Biofuels in China: An Analysis of the Opportunities and Challenges of Jatropha curcas in Southwest China.

54. Jatropha curcas biodiesel production in Kenya: Economics and potential value chain development for smallholder farmers

55. Livelihoods and Forest Resources in Aceh and Nias for a Sustainable Forest Resource Management and Economic Progress

56. Agroforestry on the interface of Orangutan Conservation and Sustainable Livelihoods in Batang Toru, North Sumatra. 
58. Assessing the Hydrological Situation of Talau Watershed, Belu Regency, East Nusa Tenggara.

59. Kajian Kondisi Hidrologis DAS Talau, Kabupaten Belu, Nusa Tenggara Timur.

60. Kajian Kondisi Hidrologis DAS Kapuas Hulu, Kabupaten Kapuas Hulu, Kalimantan Barat.

61. Lessons learned from community capacity building activities to support agroforest as sustainable economic alternatives in Batang Toru orang utan habitat conservation program (Martini, Endri et al.)

62. Mainstreaming Climate Change in the Philippines.

63. A Conjoint Analysis of Farmer Preferences for Community Forestry Contracts in the Sumber Jaya Watershed, Indonesia.

64. The highlands: a shared water tower in a changing climate and changing Asia

65. Eco-Certification: Can It Deliver Conservation and Development in the Tropics.

66. Designing ecological and biodiversity sampling strategies. Towards mainstreaming climate change in grassland management.

67. Towards mainstreaming climate change in grassland management policies and practices on the Tibetan Plateau

68. An Assessment of the Potential for Carbon Finance in Rangelands

69 ECA Trade-offs Among Ecosystem Services in the Lake Victoria Basin.

69. The last remnants of mega biodiversity in West Java and Banten: an in-depth exploration of RaTA (Rapid Land Tenure Assessment) in Mount Halimun-Salak National Park Indonesia

70. Le business plan d'une petite entreprise rurale de production et de commercialisation des plants des arbres locaux. Cas de quatre pépinières rurales au Cameroun.

71. Les unités de transformation des produits forestiers non ligneux alimentaires au Cameroun. Diagnostic technique et stratégie de développement Honoré Tabuna et Ingratia Kayitavu.

72. Les exportateurs camerounais de safou (Dacryodes edulis) sur le marché sous régional et international. Profil, fonctionnement et stratégies de développement.

73. Impact of the Southeast Asian Network for Agroforestry Education (SEANAFE) on agroforestry education capacity.

74. Setting landscape conservation targets and promoting them through compatible land use in the Philippines.

75. Review of methods for researching multistrata systems.

76. Study on economic viability of Jatropha curcas L. plantations in Northern Tanzania assessing farmers' prospects via cost-benefit analysis

77. Cooperation in Agroforestry between Ministry of Forestry of Indonesia and International Center for Research in Agroforestry

78. "China's bioenergy future. an analysis through the Lens if Yunnan Province

79. Land tenure and agricultural productivity in Africa: A comparative analysis of the economics literature and recent policy strategies and reforms

80. Boundary organizations, objects and agents: linking knowledge with action in agroforestry watersheds

81. Reducing emissions from deforestation and forest degradation (REDD) in Indonesia: options and challenges for fair and efficient payment distribution mechanisms

82. Mainstreaming climate change into agricultural education: challenges and perspectives

83. Challenging conventional mindsets and disconnects in conservation: the emerging role of ecoagriculture in Kenya's landscape mosaics

84. Lesson learned RATA garut dan bengkunat: suatu upaya membedah kebijakan pelepasan kawasan hutan dan redistribusi tanah bekas kawasan hutan

85. The emergence of forest land redistribution in Indonesia

86. Commercial opportunities for fruit in Malawi

87. Status of fruit production processing and marketing in Malawi 
88. Fraud in tree science

89. Trees on farm: analysis of global extent and geographical patterns of agroforestry

90. The springs of Nyando: water, social organization and livelihoods in Western Kenya

91. Building capacity toward region-wide curriculum and teaching materials development in agroforestry education in Southeast Asia

92. Overview of biomass energy technology in rural Yunnan (Chinese - English abstract)

93. A pro-growth pathway for reducing net GHG emissions in China

94. Analysis of local livelihoods from past to present in the central Kalimantan Ex-Mega Rice Project area

95. Constraints and options to enhancing production of high quality feeds in dairy production in Kenya, Uganda and Rwanda

\section{0}

96. Agroforestry education in the Philippines: status report from the Southeast Asian Network for Agroforestry Education (SEANAFE)

97. Economic viability of Jatropha curcas L. plantations in Northern Tanzania- assessing farmers' prospects via cost-benefit analysis.

98. Hot spot of emission and confusion: land tenure insecurity, contested policies and competing claims in the central Kalimantan Ex-Mega Rice Project area

99. Agroforestry competences and human resources needs in the Philippines

100. CES/COS/CIS paradigms for compensation and rewards to enhance environmental Services

101. Case study approach to region-wide curriculum and teaching materials development in agroforestry education in Southeast Asia

102. Stewardship agreement to reduce emissions from deforestation and degradation (REDD): Lubuk Beringin's Hutan Desa as the first village forest in Indonesia

103. Landscape dynamics over time and space from ecological perspective

104. Komoditisasi atau koinvestasi jasa lingkungan: skema imbal jasa lingkungan program peduli sungai di DAS Way Besai, Lampung, Indonesia

105. Improving smallholders' rubber quality in Lubuk Beringin, Bungo district, Jambi province, Indonesia: an initial analysis of the financial and social benefits

106. Rapid Carbon Stock Appraisal (RACSA) in Kalahan, Nueva Vizcaya, Philippines

107. Tree domestication by ICRAF and partners in the Peruvian Amazon: lessons learned and future prospects in the domain of the Amazon Initiative eco-regional program

108. Memorias del Taller Nacional: "Iniciativas para Reducir la Deforestación en la region Andino Amazónica", 09 de Abril del 2010. Proyecto REALU Peru

109. Percepciones sobre la Equidad y Eficiencia en la cadena de valor de REDD en Perú -Reporte de Talleres en Ucayali, San Martín y Loreto, 2009. Proyecto REALU-Perú.

110. Reducción de emisiones de todos los Usos del Suelo. Reporte del Proyecto REALU Perú Fase 1

111. Programa Alternativas a la Tumba-y-Quema (ASB) en el Perú. Informe Resumen y Síntesis de la Fase II. 2da. versión revisada

112. Estudio de las cadenas de abastecimiento de germoplasma forestal en la amazonía Boliviana

113. Biodiesel in the Amazon

114. Estudio de mercado de semillas forestales en la amazonía Colombiana

115. Estudio de las cadenas de abastecimiento de germoplasma forestal en Ecuador

116. How can systems thinking, social capital and social network analysis help programs achieve impact at scale?

117. Energy policies, forests and local communities in the Ucayali Region, Peruvian Amazon

118. NTFPs as a Source of Livelihood Diversification for Local Communities in the Batang Toru Orangutan Conservation Program

119. Studi Biodiversitas: Apakah agroforestry mampu mengkonservasi keanekaragaman hayati di DAS Konto? 
120. Estimasi Karbon Tersimpan di Lahan-lahan Pertanian di DAS Konto, Jawa Timur

121. Implementasi Kaji Cepat Hidrologi (RHA) di Hulu DAS Brantas, Jawa Timur.

122. Kaji Cepat Hidrologi di Daerah Aliran Sungai Krueng Peusangan, NAD,Sumatra

123. A Study of Rapid Hydrological Appraisal in the Krueng Peusangan Watershed, NAD, Sumatra.

\section{1}

124. An Assessment of farm timber value chains in Mt Kenya area, Kenya

125. A Comparative financial analysis of current land use systems and implications for the adoption of improved agroforestry in the East Usambaras, Tanzania

126. Agricultural monitoring and evaluation systems

127. Challenges and opportunities for collaborative landscape governance in the East Usambara Mountains, Tanzania

128. Transforming Knowledge to Enhance Integrated Natural Resource Management Research, Development and Advocacy in the Highlands of Eastern Africa

129. Carbon-forestry projects in the Philippines: potential and challenges The Mt Kitanglad Range forest-carbon development

130. Carbon forestry projects in the Philippines: potential and challenges. The Arakan Forest Corridor forest-carbon project

131. Carbon-forestry projects in the Philippines: potential and challenges. The Laguna Lake Development Authority's forest-carbon development project

132. Carbon-forestry projects in the Philippines: potential and challenges. The Quirino forest-carbon development project in Sierra Madre Biodiversity Corridor

133. Carbon-forestry projects in the Philippines: potential and challenges. The Ikalahan ancestral domain forest-carbon development

134. The Importance of Local Traditional Institutions in the Management of Natural Resources in the Highlands of Eastern Africa

135. Socio-economic assessment of irrigation pilot projects in Rwanda

136. Performance of three rambutan varieties (Nephelium lappaceum L.) on various nursery media

137. Climate change adaptation and social protection in agroforestry systems: enhancing adaptive capacity and minimizing risk of drought in Zambia and Honduras

138. Does value chain development contribute to rural poverty reduction? Evidence of asset building by smallholder coffee producers in Nicaragua

139. Potential for biofuel feedstock in Kenya

140. Impact of fertilizer trees on maize production and food security in six districts of Malawi.

\section{2}

141. Fortalecimiento de capacidades para la gestión del Santuario Nacional Pampa Hermosa:

Construyendo las bases para un manejo adaptativo para el desarrollo local. Memorias del Proyect

142. Understanding rural institutional strengthening: A cross-level policy and institutional framework for sustainable development in Kenya

143. Climate change vulnerability of agroforestry

144. Rapid assesment of the inner Niger delta of Mali

145. Designing an incentive program to reduce on-farm deforestationin the East Usambara Mountains, Tanzania

146. Extent of adoption of conservation agriculture and agroforestry in Africa: the case of Tanzania, Kenya, Ghana, and Zambia 
147. Policy incentives for scaling up conservation agriculture with trees in Africa: the case of Tanzania, Kenya, Ghana and Zambia

148. Commoditized or co-invested environmental services? Rewards for environmental services scheme: River Care program Way Besai watershed, Lampung, Indonesia.

149. Assessment of the headwaters of the Blue Nile in Ethiopia.

150. Assessment of the uThukela Watershed, Kwazaulu.

151. Assessment of the Oum Zessar Watershed of Tunisia.

152. Assessment of the Ruwenzori Mountains in Uganda.

153. History of agroforestry research and development in Viet Nam. Analysis of research opportunities and gaps.

154. REDD+ in Indonesia: a Historical Perspective

155. Agroforestry and Forestry in Sulawesi series: Livelihood strategies and land use system dynamics in South Sulawesi

156. Agroforestry and Forestry in Sulawesi series: Livelihood strategies and land use system dynamics in Southeast Sulawesi.

157. Agroforestry and Forestry in Sulawesi series: Profitability and land-use systems in South and Southeast Sulawesi.

158. Agroforestry and Forestry in Sulawesi series: Gender, livelihoods and land in South and Southeast Sulawesi

159. Agroforestry and Forestry in Sulawesi series: Agroforestry extension needs at the community level in AgFor project sites in South and Southeast Sulawesi, Indonesia.

160. Agroforestry and Forestry in Sulawesi series: Rapid market appraisal of agricultural, plantation and forestry commodities in South and Southeast Sulawesi.

\section{3}

161. Diagnosis of farming systems in the Agroforestry for Livelihoods of Smallholder farmers in Northwestern Viet Nam project

162. Ecosystem vulnerability to climate change: a literature review

163. Local capacity for implementing payments for environmental services schemes: lessons from the RUPES project in northeastern Viet Nam 

The World Agroforestry Centre is an autonomous, non-profit research organization whose vision is a rural transformation in the developing world as smallholder households increase their use of trees in agricultural landscapes to improve food security, nutrition, income, health, shelter, social cohesion, energy resources and environmental sustainability. The Centre generates science-based knowledge about the diverse roles that trees play in agricultural landscapes, and uses its research to advance policies and practices, and their implementation that benefit the poor and the environment. It aims to ensure that all this is achieved by enhancing the quality of its science work, increasing operational efficiency, building and maintaining strong partnerships, accelerating the use and impact of its research, and promoting greater cohesion, interdependence and alignment within the organization.

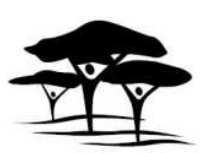

United Nations Avenue, Gigiri • PO Box $30677 \cdot$ Nairobi, $00100 \cdot$ Kenya Telephone: +254207224000 or via USA +16508336645 Fax: +254207224001 or via USA +1 6508336646

Email: worldagroforestry@cgiar.org•www.worldagroforestry.org

Southeast Asia Regional Program - Sindang Barang, Bogor 16680 PO Box 161 Bogor 16001, Indonesia Tel: +62 2518625415 - Fax: +62 2518625416 